Florida International University FIU Digital Commons

$11-1-2012$

\title{
Organized Labor and U.S. Foreign Policy: The Solidarity Center in Historical Context
}

George Nelson Bass III

Florida International University, gbass001@fiu.edu

DOI: $10.25148 /$ etd.FI12113003

Follow this and additional works at: https://digitalcommons.fiu.edu/etd

\section{Recommended Citation}

Bass, George Nelson III, "Organized Labor and U.S. Foreign Policy: The Solidarity Center in Historical Context" (2012). FIU Electronic Theses and Dissertations. 752.

https://digitalcommons.fiu.edu/etd/752 


\title{
FLORIDA INTERNATIONAL UNIVERSITY \\ Miami, Florida
}

\section{ORGANIZED LABOR AND U.S. FOREIGN POLICY: THE SOLIDARITY CENTER IN HISTORICAL CONTEXT}

\author{
A dissertation submitted in partial fulfillment of \\ the requirements for the degree of \\ DOCTOR OF PHILOSOPHY \\ in \\ POLITICAL SCIENCE \\ by
}

G. Nelson Bass III

2012 
To: Dean Kenneth G. Furton

College of Arts and Science

This dissertation, written by G. Nelson Bass III, and entitled Organized Labor and U.S. Foreign Policy: The Solidarity Center in Historical Context, having been approved in respect to style and intellectual content, is referred to you for judgment.

We have read this dissertation and recommend that it be approved.

$\begin{array}{r}\hline \text { Guillermo J. Grenier } \\ \hline \text { Felix Martin } \\ \hline \text { Nicol C. Rae } \\ \hline \text { Richard Tardanico } \\ \hline \text { Ronald W. Cox, Major Professor }\end{array}$

Date of Defense: November 1, 2012

The dissertation of G. Nelson Bass III is approved.

$\begin{array}{r}\text { Dean Kenneth G. Furton } \\ \text { College of Arts and Sciences } \\ \hline \begin{array}{r}\text { Dean Lakshmi N. Reddi } \\ \text { University Graduate School }\end{array}\end{array}$

Florida International University, 2012 


\section{ACKNOWLEDGMENTS}

I wish to first thank my parents, Carolyn and Nelson Bass Jr., for their constant support, guidance and encouragement, which has given me the drive to achieve my goals. In addition, I owe a special debt of gratitude to my amazing and wonderful wife, Lindsay, who always believed in me. I could have never done this without her support, inspiration, and love.

I am enormously thankful to the members of my dissertation committee: Dr.

Ronald W. Cox, Dr. Guillermo Grenier, Dr. Felix Martin, Dr. Nicol C. Rae, and Dr. Richard Tardanico, whose comments and feedback were of invaluable assistance to me in the process of writing and completing my dissertation. I am eternally grateful to Dr. Cox, who has been a source of guidance for the last six years, both intellectually and as a role model for what every professor should strive to be.

Finally, I would like to thank the Department of Politics and International Relations at Florida International University for granting me a Graduate Teaching Assistantship, which provided me with the opportunity to attend graduate school and allowed me to gain valuable experience with excellent professors. 


\title{
ABSTRACT OF THE DISSERTATION \\ ORGANIZED LABOR AND U.S. FOREIGN POLICY: THE SOLIDARITY CENTER IN HISTORICAL CONTEXT
}

\author{
by \\ G. Nelson Bass III \\ Florida International University, 2012 \\ Miami, Florida \\ Professor Ronald W. Cox, Major Professor
}

During the Cold War the foreign policy of the American Federation of Labor and Congress of Industrial Organizations (AFL-CIO), was heavily criticized by scholars and activists for following the lead of the U.S. state in its overseas operations. In a wide range of states, the AFL-CIO worked to destabilize governments selected by the U.S. state for regime change, while in others the Federation helped stabilize client regimes of the U.S. state. In 1997 the four regional organizations that previously carried out AFLCIO foreign policy were consolidated into the American Center for International Labor Solidarity (Solidarity Center). My dissertation is an attempt to analyze whether the foreign policy of the AFL-CIO in the Solidarity Center era is marked by continuity or change with past practices. At the same time, this study will attempt to add to the debate over the role of non-governmental organizations (NGOs) in the post-Cold War era, and its implications for future study.

Using the qualitative "process-tracing" detailed by of Alexander George and Andrew Bennett (2005) my study examines a wide array of primary and secondary sources, including documents from the NED and AFL-CIO, in order to analyze the 
relationship between the Solidarity Center and the U.S. state from 2002-2009.

Furthermore, after analyzing broad trends of NED grants to the Solidarity Center, this study examines three dissimilar case studies including Venezuela, Haiti, and Iraq and the Middle East and North African (MENA) region to further explore the connections between U.S. foreign policy goals and the Solidarity Center operations.

The study concludes that the evidence indicates continuity with past AFL-CIO foreign policy practices whereby the Solidarity Center follows the lead of the U.S. state. It has been found that the patterns of NED funding indicate that the Solidarity Center closely tailors its operations abroad in areas of importance to the U.S. state, that it is heavily reliant on state funding via the NED for its operations, and that the Solidarity Center works closely with U.S. allies and coalitions in these regions. Finally, this study argues for the relevance of "top-down" NGO creation and direction in the post-Cold War era. 


\section{TABLE OF CONTENTS}

CHAPTER

PAGE

I.

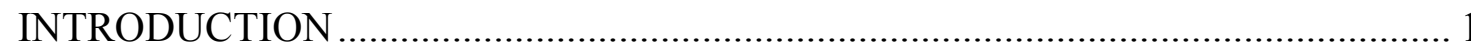

THE AFL \& AFL-CIO FOREIGN POLICY AND BUSINESS UNIONISM: COLD

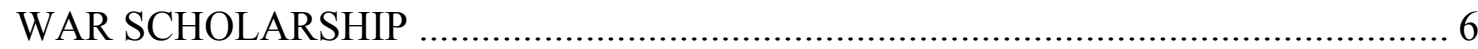

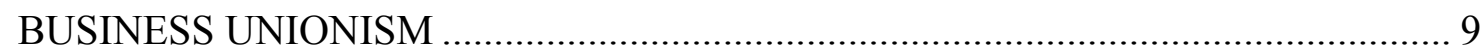

ANTI-COMMUNISM, LABOR ELITES, CAPTURE, OR ALL THREE.................. 14

COLD WAR SCHOLARSHIP ON AFL-CIO FOREIGN POLICY ………................. 14

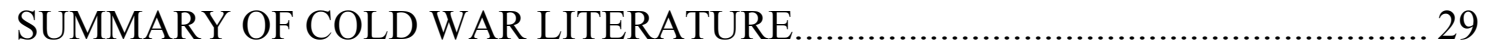

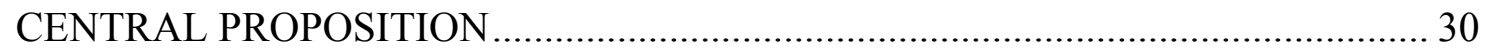

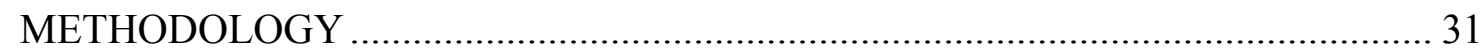

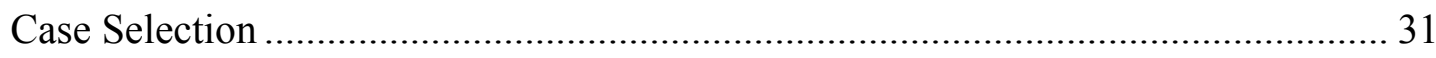

Process Tracing and Historical Explanation as Methodology …………………….... 32

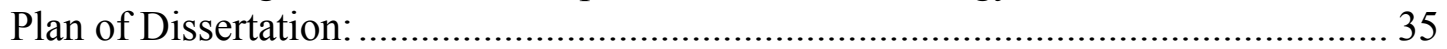

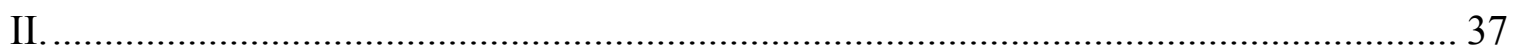

FEDERATION FOREIGN POLICY DURING THE COLD WAR ............................. 37

Gompers and the Early Roots of AFL Foreign Policy ……………………………..... 39

The Institutional Evolution of the Labor-State Relationship ....................................... 41

The Federation Foreign Institutes: A Primer............................................................. 49

The AFL and AFL-CIO \& the Cold War: Stabilization............................................... 55

The AFL and AFL-CIO \& the Cold War: Destabilization........................................... 76

Shifting Funding Flows: Labor, the NED, and "Democracy Promotion" .................. 84

The Creation of the National Endowment for Democracy ......................................... 87

The NED and Democracy Promotion as "Limited Democracy" or Polyarchy .......... 91

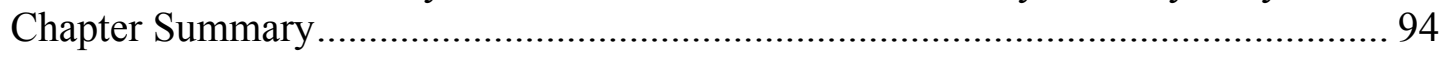

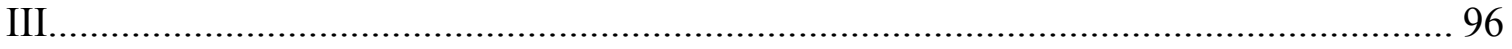

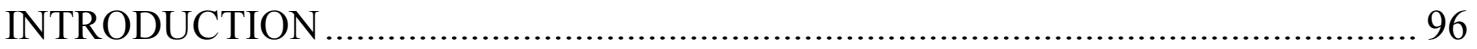

THE SOLIDARITY CENTER CREATION AND EFFORTS TO OPEN THE BOOKS

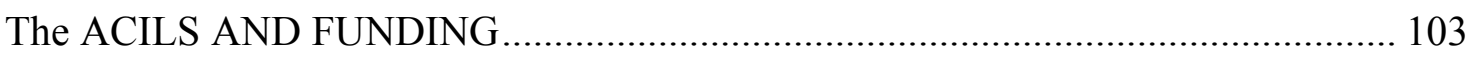

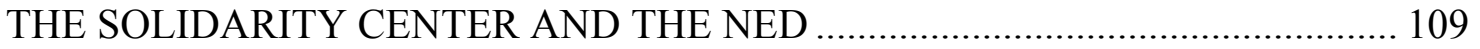

ACILS-NED EUROPEAN GRANTS 2001-2009 ................................................... 114

ACILS-NED MIDDLE EAST \& NORTH AFRICA (MENA) GRANTS 2001-2009 121

ACILS-NED LATIN AMERICAN AND CARIBBEAN GRANTS 2001-2009........ 125

ACILS-NED ASIA AND CHINA GRANTS 2001-2009 …………....................... 128

IMPLICATIONS OF THE SOURCES OF SOLIDARITY CENTER FUNDING .... 131

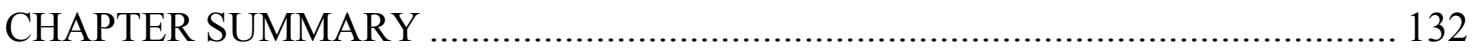




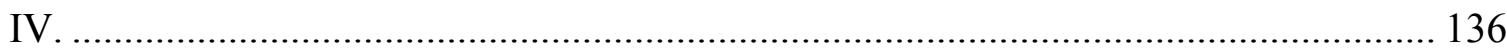

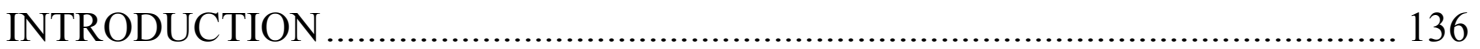

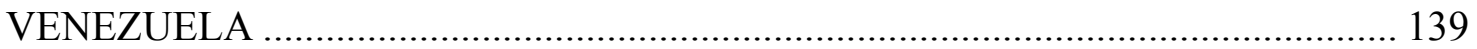

HAITI: "STOP AND GO DEMOCRACY-BUILDING” ......................................... 159

IRAQ, THE MIDDLE EAST AND THE “WAR ON TERROR” ........................... 185

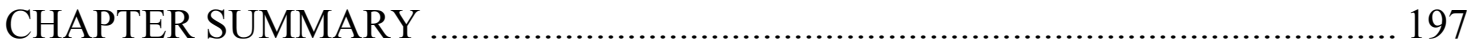

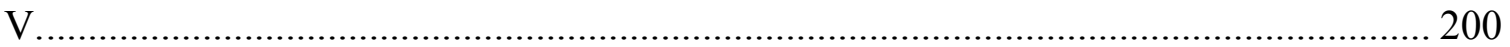

THE ACILS AND NGO V. STATE POWER ...................................................... 200

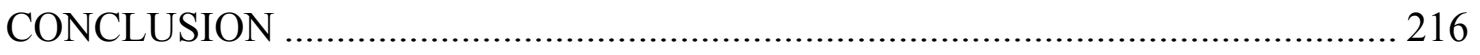

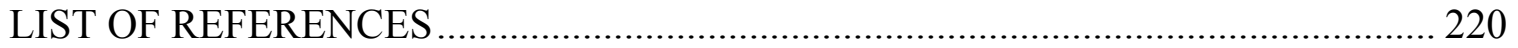

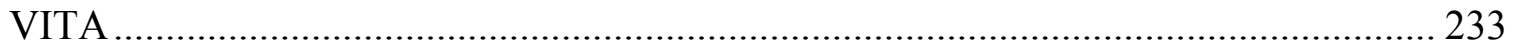




\section{CHAPTER I.}

\section{INTRODUCTION}

For the vast majority of its history the politics of the American labor movement has been defined by its adherence to the principles of "business unionism." Rather than mobilizing as a political party or being vehicles of radical change, the largest and most successful workers organizations in the United States have been defined by their acceptance of the basic tenets of capitalism, their focus on certain industries to the exclusion of others, and critically for the present research project, strong support for American foreign policy goals. At least for a significant part of the $20^{\text {th }}$ century this strategy "worked" for a segment of American workers in high-profit, unionized industries in that it provided job security, higher wages, defined benefits, and rising standards of living for its members. Moreover, with a third of the American workforce organized by 1945, there was significant pressure for employers in non-unionized industries to keep wages high, lest unions attempt to encroach on the unorganized. (Massey 2009, 12-13).

At the same time business unionism was flourishing at home, American labor was accused by scholars and activists of supporting U.S. foreign policy through both overt and covert means throughout the Cold War. Besides giving vocal support to direct military interventions in places like Korea and Vietnam during this time period, the American Federation of Labor (AFL) and later the American Federation of LaborCongress of Industrial Organizations (AFL-CIO) engaged in a variety of campaigns to bolster un-democratic and authoritarian regimes friendly with the U.S. state and to destabilize governments which ran afoul of American geostrategic interests (Scipes 2010; 
Sims 1992; Spalding Jr. 1988). Thus, the AFL and later AFL-CIO were accused of utilizing a dual-pronged strategy in regard to foreign policy that incidentally mirrored Samuel Gompers famous slogan of "rewarding friends and punishing enemies." However, in this regard the "friends" and "enemies" were not those of labor, but rather those of the American state. For "friends" of the American government, the AFL-CIO actively worked to create or maintain "apolitical" unions under the auspices of the business unionism model, while for "enemies" of the U.S. state, the foreign arms of the federation worked to create highly politicized labor organizations to confront regimes deemed hostile, regardless of the veracity of those claims.

Thus, scholars detailed instances where the foreign arms of the AFL-CIO worked either in tandem with the U.S. state or on its behalf around the world during the Cold War. In countries as diverse as British Guiana (Rabe 2005; Waters Jr. and Daniels 2006), Brazil (Black 1977; Gribbin 1979; Welch 1995), Chile (Hirsch and Muir 1987; Scipes 2010), Guatemala (Buhle 1999; Morris 1967), and Angola (Buhle 1999; Sims 1992), scholars alleged the AFL-CIO used its four foreign institutes to destabilize governments selected by the U.S. state for regime change. Generally, these destabilization programs were blamed for bringing to power right-wing authoritarian governments amenable to U.S. business and strategic interests. Critically, the strategies behind these actions were explicitly political. That is, workers were organized against the political ideology and regime in each situation, generally through programs aimed at combating communist or leftist influence (regardless of whether the charges of communist influence were merited) (Buhle 1999; Sims 1992). In some cases, labor worked with U.S. intelligence agencies to 
funnel money to existing oppositional labor movements or, in cases where none existed, to create workers organizations that would undermine the regime in question.

Paradoxically, in places like Haiti (Sims 1992; Robinson 1996; Spalding Jr. 1988), El Salvador (Deere 1982; Smyth 1987), Grenada (Boodhoo 1986; Spalding 1992), South Africa (Cohen 1979), Nigeria (Cohen 1979; Godfried 1987,), the Philippines (Scipes 2010; Shorrock and Selvaggio 1986), and Russia (Buhle 1999) the foreign institutes of the AFL-CIO did exactly the opposite by encouraging apolitical "bread and butter" business unions. Therefore, these scholars argued that under the mantra of "free" trade unionism the foreign institutes were working to stabilize or bolster authoritarian and dictatorial regimes by emboldening workers with the notion that the "proper" role for labor was at the collective bargaining table rather than through explicitly political activities. The four foreign institutes often created parallel unions to undermine or weaken "politicized" or "leftist" unions within these countries by bleeding them of members and resources. Therefore, although the specific strategies invoked were sometimes similar, for example creating competing union structures, the degree of politicization involved depended (at least in the countries discussed above) on the designs of the U.S. state (Robinson 1996; Scipes 2010; Sims 1992).

The scholarly literature referenced above, which examines the activities of the AFL-CIO abroad during the Cold War, is fully explored in chapter two. However, the principal focus of this dissertation concerns the era encompassing 1997 to the present. Following on the heels of the first open election for leadership within the AFL-CIO in 1997, the four regional institutes were consolidated into a new structure: the American Center for International Labor Solidarity (ACILS) by the John Sweeney regime. At least 
in theory, the Solidarity Center (as it is generally referred to) was supposed to embody a break between past foreign policies where labor "followed the flag" to a new orientation that focuses on a broader vision of labor internationalism concerned with confronting the ever expanding power of multinational corporations vis-à-vis global capitalism.

Therefore, the key research question this dissertation seeks to address is whether the foreign policy of the AFL-CIO during the Solidarity Center era is best explained by its relationship with the U.S. state. In order to examine this research question, several related questions must be addressed. First, is the Solidarity Center following U.S. state funding for its operations abroad? Second, is the Solidarity Center overwhelmingly dependent on this funding from the U.S. state? Each of these questions is examined by delving into the patterns of funding between the National Endowment for Democracy (NED) and the American Center for International Labor Solidarity. These funding patterns are explored in chapter three, with a specific focus on how the ACILS is both reliant on U.S. funding, and also tracks its funding shifts with the U.S. state in terms of geostrategic importance. The third question that is related to the primary research question of this work is whether the Solidarity Center is working closely with U.S. allies and coalitions of allies in the regions and areas where it receives funding and is addressed in chapter four. In addition, this work also seeks to add modestly to the debate over the power of NGOs in relation to the state. For some scholars, the end of the Cold War and technological advances have led to an increase in NGOs which are able to assert a new found power, even over the traditional actors in the Westphalian system (Mathews 1997). While for others, NGOs must be viewed as part of a "top-down" process, that is, states are not only allowing NGOs to proliferate, they are actively encouraging and creating 
organizations to further their interests (Reimann 2006). Most critically, my research fits nicely with recent scholarship that argues that "international" NGOs or "INGOs" are increasingly tied in organization, structure and funding to their home governments (Stroup 2012). Thus, my dissertation seeks to add to this debate by analyzing one NGO, the Solidarity Center, and its relation to the U.S. state.

To answer these questions, this research utilizes the process tracing method to track changes in the foreign policy of the AFL-CIO from the Cold War to the present, with a special focus on the era after the creation of the Solidarity Center by labor elites in 1997. To determine whether there has indeed been a shift in AFL-CIO foreign policy in the Solidarity Center era I will examine and contrast two historical periods. The first begins shortly before the end of World War II (before the merger of the AFL and CIO) when the then AFL establishes linkages with the CIA in order to bolster unions in Europe and continues on throughout the Cold War period. However, because of the attention paid by previous scholars to this first timeframe, which importantly includes the creation of the NED, this history will be succinctly reviewed and summarized in one chapter (Chapter Two). The second period under review begins with an examination of the creation of the Solidarity Center in 1997 and examines its undertakings through the current moment.

The process tracing method will allow me to examine the degree to which there is a systematic fit between military and economic aid from the U.S. state and the foreign policy of the Solidarity Center. Process tracing as a methodology allows the researcher to track the historical changes that illuminates the nuances, causes, and consequences of specific patterns of activity. Process tracing is especially useful for understanding policy 
changes over time by analyzing the decision-making and policy outcomes of various actors. Moreover, it is especially helpful when dealing with a single case study, in this case the Solidarity Center, and its evolution (or possible lack thereof) over time.

\section{THE AFL \& AFL-CIO FOREIGN POLICY AND BUSINESS UNIONISM: COLD}

\section{WAR SCHOLARSHIP}

Previous scholarship regarding the foreign policies of the AFL-CIO has tended to fall into two loosely coherent categories. The first category consisted of journalists, scholars and activists describing the activities of the AFL-CIO abroad. This descriptive literature exposed what the Federation was doing in places like Brazil, British Guiana, Haiti, El Salvador, South Africa, Angola, the Philippines, South Korea and Chile out of the sight of both the American public and the AFL-CIO rank-and-file. That is, during the 1960s, 70s, and early 80s, most of what was written about AFL-CIO activities abroad was expository in nature and not necessarily defined by a theoretical approach. Labor activists, journalists, and key players within the U.S. state generally wrote about specific cases of AFL-CIO-U.S. state collaboration in terms of uncovering the reality on the ground rather than the processes and mechanisms that enabled this behavior. Generally, the "why" question usually assumed that labor's foreign policy was a result of leadership that privileged anti-communism and linkages with the state over rank-and-file member concerns and business union tendencies within the AFL-CIO itself. For the most part, work from this era reflected concerns within Latin America although other regions were covered to a lesser degree. A second branch of scholarship began to take shape in the $80 \mathrm{~s}$, and was more robust in nature. That is, in the vein of traditional social science 
research scholars wrote manuscripts that attempted to shed light on why the Federation engaged in certain activities abroad. Although still largely descriptive in nature, work by Sims (1992), Scipes (2010), and others explored how labor's foreign policy was created and what types of linkages existed between the foreign institutes and the U.S. state.

As Kim Scipes notes in AFL-CIO's Secret War Against Developing Country Workers, the most thorough examination of the topic to date, the "why" question in regard to AFL-CIO foreign policy can be broken into several threads. The first grouping saw AFL-CIO foreign policy as being externally imposed, that is to say that the AFLCIO was being used by the U.S. state to engage in imperialistic exploits overseas (Scipes 2010, xxi). These exposes were only loosely built on a theory, but primarily focused on examining the role of the CIA along with other government agencies in funding labors' foreign policy. The second thread began to emerge in the late $80 \mathrm{~s}$ and somewhat rejected the notion that labor's foreign policy was being completely imposed, but rather argued it was a combination of internal construction and "infiltration" by U.S. state interests (Ibid.). These works argued for a more robust examination of the ways in which state interests and dominant labor-elite personalities combined to "undermine" the AFL-CIO's work abroad. Scipes (2010, xii) contends that the newest thread in scholarship examines how the internal structure and politics of business unionism eventually morphed into "labor imperialism" which dominates the foreign policy of the Federation, as opposed to other scholars who located policy as externally imposed. On the basis of the sociological theory of imperialism developed by Jan Nederveen Pieterse, Scipes (2010, xii) contends that AFL-CIO foreign policy “...tries to dominate foreign labor movements, especially in developing countries and, therefore, is an imperialist foreign policy". 
My dissertation takes a different tact. Rather than attempting to explain causation of the Federation's policies abroad, this work seeks to determine if there has been a shift away from following the lead of the U.S. state in the Solidarity Center era. Whether the AFL-CIO followed the lead of the U.S. state out of an internally developed businessunionism turned imperialism, or because the American government has "captured" the foreign arms of the AFL-CIO is less important for this dissertation than analyzing whether the Federation has moved away from the "follow the flag" policies that dominated during the Cold War. As will be discussed briefly below and in depth in chapter two, there is more than enough evidence to suggest that the AFL and later AFLCIO engaged in systematic efforts to undermine regimes which ran counter to U.S. geostrategic interests and to support non-democratic regimes which were client states of the U.S. during the Cold War. Therefore, the larger question is this: has anything changed with the creation of the American Center for International Labor Solidarity?

However, in order to insert myself in the conversation it is crucial to evaluate the literature to this point. The literature review begins with a brief overview of "business unionism" as much of the previous work revolves around a conception of its place of privilege within the American labor movement. Business unionism defines the largest American labor movement and also is generally adopted by scholars examining foreign policy as at least a partial explanation of labor's foreign policy. Often the linkages between business unionism and labor's foreign policy is explicit, while at other times it is assumed, however discussing AFL-CIO foreign policy without discussing the role of business unionism generally is nigh impossible. Therefore, understanding the main tenets of business unionism is critical to analyzing most of the scholarship and is 
discussed below. Following this section, I analyze the role of anti-communism, labor leadership, and material concerns as other inputs in Federation foreign policy during the Cold War with an emphasis on the linkages between the U.S. state and the AFL-CIO.

\section{BUSINESS UNIONISM}

In Solidarity Divided, Bill Fletcher Jr., and Fernando Gapasin (2008, ix) describe a meeting between leaders of the Service Employee International Union (SEIU) and the South African National Education, Health \& Allied Workers Union (NEHAWU) in Johannesburg in 2001 as a powerful illustration of the key differences between "business" and "social justice" unionism:

A young progressive SEIU local union leader from the West Coast, commenting on the role of the union in political action, noted what must have seemed obvious to him: that the role of a union is to represent the interests of its members. The representatives of NEHAWU offered a careful and diplomatic reply: 'Comrades,' they began, 'the role of the union is to represent the interests of the working class. There are times when the interests of the working class conflict with the interests of the members of our respective unions.' Silence descended on the room ... Time seemed to have stopped.

This passage illuminates the tension between two very different versions of unionism. The representative of the SEIU was explaining in a matter-of-fact manner the main tenet of the "business unionism" model that the AFL and later AFL-CIO has advocated, both at home and at times abroad, since it first formed in the late $19^{\text {th }}$ century. On the other hand, the representative of the NEHAWU was putting forth a conception of labor organization that was in many ways directly opposed to the framework described by the AFL-CIO. As the authors of Solidarity Divided make clear, this miscommunication has a deeper historical context, and although their own work only tangentially touches upon 
AFL-CIO foreign policy, this divide explains much of what has been written in regard to the Federation's operations overseas. That is, in its simplest terms, most of the literature from the Cold War era makes (at least) two assumptions: descriptively: that business unionism has played a major role in AFL-CIO foreign policy, and prescriptively: that business unionism is not the most appropriate labor ideology for international organizing.

The two conflicting "mission statements" presented above illustrate a simple but significant difference between business unionism and a different sort of vision for labor. Moreover, these two agendas capture part but not all of the variables in play when considering various frameworks for understanding the organization of workers. However, there are numerous ways to arrange labor organizations in a differentiated manner. Among the types of unions described by scholars there are revolutionary, business, industrial, craft, trade, employer-led, social, and social justice unionism. Many of these labels have a very specific temporal and spatial relevance. For example, the Industrial Workers of the World (IWW) are a smaller yet at one time significant revolutionary, industrial union in the United States that (mainly) up until World War I sought to unionize every worker regardless of occupation and to "abolish the wage system." However, groups like the IWW have been the exception not the rule in the United States, where the dominant strand of labor organization has fallen broadly under the category of "business unionism." More to the point, the AFL and later AFL-CIO in its actions and outlook fit comfortably into the business unionism framework as a whole for over a century, especially domestically and generally overseas in their interactions with foreign labor organizations.

${ }^{1}$ The Preamble to the Constitution of the Industrial Workers of the World, 1908. 
The term "business unionism" refers to a specific set of ideological and strategic assumptions by labor organizations regarding the relationship of organized workers to both capital and the state. Labor activists and historians use this term to describe a consensual relationship between workers and capitalists. Also referred to as "serviceprovider unionism," "bureaucratic business unionism," or "pure and simple unionism," the underlying assumptions vary slightly from author to author but basically rest upon a series of premises related to the passage above. A "business union" is mainly identified by its focus on representing the immediate interests of its members rather than large segments or (more broadly) all the members of the working class.

One of the first (though likely not the first) to use the term "business unionism" in these terms was Ronald F. Hoxie (1917, 45), who wrote that besides focusing primarily on its members, business unionism aimed to gain “...higher wages, shorter hours, and better working conditions, regardless for the most part of the welfare of the workers outside the particular organic group, and regardless in general of political and social considerations except in so far as these bear directly upon its own economic ends.” In terms of U.S. domestic politics, Hoxie argues that unions of this sort accept, if not embrace the "natural order" of capitalism and are primarily interested in collective bargaining (Hoxie 1917, 45). The "natural order" was especially relevant to AFL-CIO

${ }^{2}$ Labor Law for the Rank \& Filer, by Staughton Lynd and Daniel Gross, 2008, PM Press at 73 .

${ }^{3}$ Solidarity Divided: The Crisis in Organized Labor and a New Path to Social Justice, by Bill Fletcher Jr., and Fernando Gapasin, 2008 University of California Press at 30.

${ }^{4}$ Reference to Samuel Gompers, founder of the AF of L and foremost proponent of business unionism. 
foreign policy during the Cold War in places like El Salvador, Haiti, South Africa, and South Korea where the Federation nurtured and developed, or in some cases, created apolitical trade unions. In these cases the foreign arms of the AFL-CIO was keen to emphasize passivity in politics and to demand rights at the collective bargaining table exclusively.

Thus, the focus on collective bargaining, or the legal contract drawn up between the union and employer, is the focal point of business unionism activity. As will be made clear in chapter two, the collective bargaining agreement was often the lynchpin of Federation foreign policy. Foreign workers were trained to view these contracts as the end-all be-all for labor activity in countries where the U.S. state supported the regime in power. In other cases, the Federation trained its workers to focus on anti-communism and resistance to regimes that were outside of the U.S. sphere of influence. Generally speaking, this resistance was reshaped as soon as a regime could be installed that was amenable to the American government, in which case workers would be trained to again rely on the collective bargaining agreement as the main focal point of union activity.

The attachment to and acceptance of the status quo naturally leads to several other key assumptions of business unionism. First, that worker's "sell" their labor in the marketplace like any other input or commodity and thus, that it is most desirable to sell that commodity for as high a price as possible. Second, that in order to obtain the highest price for their work they must bargain away certain demands, such as control of production, management decision-making, and relegate strikes and direct action to "last resort" tactics. Finally, under all of these previous assumptions, a key component for unions is their competitiveness with other workers for contracts and employment. As a 
related corollary, business unionism by its nature assumes that the American political body lacks any serious class cleavage within its system of capitalism. The "consensual" view of American politics is most often associated with Louis Hartz and has a long history within American political culture dating back at least to the Horatio Alger novels of the $19^{\text {th }}$ century. However, later scholars such as Sean Wilentz (1984) have debated the notion that American political culture has been defined by its consensual nature. Importantly, some of the earliest works attempting to study labor and foreign policy emphasized this business-unionism-as-consensual American politics outlook. For example, John P. Windmuller $(1963,105)$ wrote in 1963 that:

In its main outlines, the foreign policy of the United States has had and will continue to have broad support from most segments of organized labor... Labor's support has ranged from the elaborate resolutions and foreign policy statements of conventions and executive boards to testimony before congressional committees financially or substantively concerned with foreign policy. All this could hardly be otherwise, American labor is so integral a part of American society that its perception of the national interest coincides with and is actually a part of the national consensus. Sharp differences between labor and the rest of the country over the domestic social and economic order, the character of our relations with other nations, and the definition of our national security do not exist, whether under a Republican or Democratic administration.

For scholars like Windmuller, the cleavages in labor's foreign policy erupted over tactical differences between the $\mathrm{CIO}$ and the AFL prior to and immediately following their merger in 1955, not the connections between labor and state. Further, as will be discussed below, Windmuller maintained this view of labor's foreign policy even after the publication of several articles in major periodicals that highlighted the linkages between American intelligence agencies and the AFL-CIO in Latin America. 
Crucially, the importance placed upon business unionism as a "shaping force" of AFL-CIO foreign policy is one of the main backbones in the literature. For some scholars, such as Scipes (2010), Filipelli (1989), and Carew (1998), the AFL-CIO's business unionist strategy was a major component to understanding the activities of the Federation overseas. The most sophisticated framework, advanced by Scipes (2010), argues that business unionism in the U.S. "led to at least passive, and later, active support for U.S. imperialism" (xxii). On the other hand, the earliest literature on AFL-CIO foreign policy gave less attention to business unionism, and placed importance on the capture of AFL-CIO apparatuses (Morris 1967) while others blended the two (Sims 1992). Still other works focused on the politics of labor elites and their interactions with the business unionism ideology of the AFL-CIO (Buhle 1999). However, a holistic approach to the literature suggests that outside of the sociological theory put forward by Scipes (2010), much of the literature used varying degrees of all of these explanations to understand labor's foreign policy during the Cold War, resulting in a sometimes opaque melting pot of work which often compounded description with prescription.

\section{ANTI-COMMUNISM, LABOR ELITES, CAPTURE, OR ALL THREE... COLD WAR SCHOLARSHIP ON AFL-CIO FOREIGN POLICY}

Much of the scholarship concerning the AFL-CIO and its foreign arms during the Cold War came out in the form of exposes, which generally linked the Federation with U.S. geostrategic aims for containing communism. As stated above, these exposes were mostly critical of AFL-CIO activities abroad, either from a pragmatic standpoint (criticizing linkages between the Federation and the American government) or from an 
ideological point of view (workers abroad are being manipulated). As early as 1964, Stanley Meisler wrote a scathing critique of AFL-CIO activities in The Nation that called into question the assertion that "Unions of America are anything but agencies of the government and big business," especially in their Latin American operations (Meisler 1964, 133). Meisler broke down the broad outlines of how the American Institute for Free Labor Development (AIFLD) worked with President Kennedy's Alliance for Progress to train Latin American workers in business unionism and to engage in activities such as supplying funding for housing projects in Mexico, British Guiana, and Honduras. Meisler $(1964,136)$ also discusses the capture of the Standard Fruit Company Workers Union by AIFLD graduates from "communist" control at the same time USAID funded housing was being erected in Honduras as a political pay-off for union members who supported AIFLD and U.S. policy. In short, Meisler contrasted the popular narrative that the Soviet trade unions were the only labor organizations with linkages to a patron state by illustrating the manner in which AIFLD was involved with the U.S. in undermining regimes alleged to be under communist influence or Castro-esque in nature.

This sort of expose journalism continued with articles by Henry W. Berger and Sidney Lens who criticized the Federation for the virulent anticommunism which often was to the "right" of U.S. business. Sidney Lens $(1965,10)$ described the main players behind the foreign policy of the AFL-CIO and described two decades of Federation operations overseas as “.... what would be called 'outside subversion' if the other side were doing it." Lens' journalistic account specifically argues that the AFL-CIO has taken several steps beyond acceptable trade-union behavior. First, the AFL-CIO has “.... acted virtually as an agent for the American Government on a broad basis", except in a few 
cases where the AFL-CIO policy was "more" anti-communist than the U.S. state (Ibid.). Second, it has been so active that it has become an "internal" actor in the affairs of other states. Finally, according to Lens (10), the Federation has become involved in intelligence work, at least "indirectly." The mechanisms for these activities included both training courses and social programs for foreign workers.

At the time of his writing, Lens $(1965,16)$ (citing AIFLD reports) documents 20,000 students who had undergone trade-union training, with 317 of those students receiving further instruction in the U.S. along with being paid by AIFLD for a period of at least nine months after returning to their home country. Moreover, training for AIFLD students encompasses classes on collective bargaining, “...two sessions on the history of U.S. labor, two on the U.S. system of government, one on 'totalitarianism,' one on communism in Latin America, one on the politics of U.S. labor, one on the Sino-Soviet conflict, and one on the German labor movement" (Ibid.). As Lens noted (16), it was less than clear just how these Latin American graduates could apply these lessons to their own struggles against oligarchic control.

Lens' article places its emphasis on the "vehement" anti-communism of AFL-CIO leadership, specifically George Meany and his right hand man, Jay Lovestone (who, like many of the AFL-CIO foreign policy cadre, were drawn from the ranks of disillusioned former communists). It is the leadership, removed from rank-and-file accountability, in this account that is responsible for the tangled web of labor and state. Lens $(1965,27)$ argues that the (at the time recent) creation of the African-American Labor Center (AALC) was based in this black and white view of the world, writing that the target for the AALC was "...not so much the Communists, who are weak, as it is the neutralists. 
Since Lovestone considers neutralism an 'aide-de-camp' of communism, it is understandable that he should want to contain it and roll it back" (Ibid.). Lens (27) goes on to describe African unionists who felt they had been treated in a patronizing manner, with labor operatives less interested in their struggles against colonialism or their domestic situation than in replicating American business unionism on the continent. In addition, like Meisler, the overarching concern for Lens seems to be whether the relationship between the state and the AFL-CIO is based in the interests of domestic and foreign workers or on the desires of vehemently anti-left labor elites like Meany and Lovestone.

In another article for The Nation in 1967, Henry W. Berger gave a similar overview of AFL-CIO activities abroad, arguing that although historical events have at times intervened (for example, the merger of AFL and CIO in 1955), the foreign policy of the Federation, especially its support for American foreign policy goals, has been steadfast since the days of Samuel Gompers. Berger $(1967,80)$ believes this outlook to be based partly on pragmatic concerns: developing unions abroad that would demand higher wages would limit competition for jobs and at the same time develop a foreign consumer class to absorb American products. Interestingly, while Berger (81) maintains the AFL-CIO policy "character" was homegrown, foreign policy activity "intensified" as a result of CIO competition in the mid-1930s. Moreover, Berger (81) argues that the conservative business-unionism mindset of the Federation was evident in foreign operations "...well before it can be seriously argued that the Soviet Union was in any active sense intervening" around the globe. In other words, Berger claims (as will Scipes and others later) that intervention in foreign lands by organized labor was not a pragmatic 
response to the exigencies of the Cold War, but rather part and parcel of the businessunionism ideology of American labor. Berger (82) discusses the AFL's overseas work during the end and immediately following World War II and outlines the creations of dual-unions in France, Italy, Greece, and Germany and contends “...the AFL increasingly tied its overseas activities to United States Government agencies, including the CIA". Without attribution, Berger (83) writes that approximately $\$ 110$ million in U.S. government funds were funneled through the AFL in 1963. These funds were used for educational activities and also "social projects" including housing, banks, and union halls. Most importantly all were "channeled to the 'proper' political recipients and favored unionists" (83). Again, the emphasis was on how funds from the U.S. state were being doled out as political rewards for labor organizations abroad.

In line with the expose-oriented literature of the time, George Morris published CIA and American Labor in 1967, which exposed the linkages between American intelligence agencies and foreign arms of the AFL and later the AFL-CIO. Morris (1967) contended that the CIA had in effect taken over, or at the very least heavily infiltrated, the foreign apparatuses of the Federation and therefore the AFL-CIO abroad was acting as a mere appendage to U.S. geostrategic aims.

The same year Morris' book was published, John P. Windmuller $(1967,215)$ argued in "The Foreign Policy Conflict in American Labor" that the claims by Berger regarding U.S. state funding for AIFLD were "far less than the much larger estimates recently advanced." Much more optimistic in his analysis of labor's foreign policy, Windmuller devotes very little time to countering accusations made against AIFLD and the AFL-CIO, instead focusing on the intentions of the AFL-CIO in their Latin American 
operations and the internal squabbles between Walter Reuther and George Meany. In Windmuller's (214) view, AIFLD activities in Latin America “....stems from a genuine sense of mission to help weak organizations acquire the means for self-sustained growth, nurtured by activities centering on services and bargaining..." which, in his words, was "indispensable." Windmuller focuses on leadership as the driving force of AFL-CIO foreign policy, and specifically the battles between Reuther and Meany; battles Windmuller argued Meany and the AFL wing of the AFL-CIO won. Windmuller (226) argues that "[i]n the area of foreign policy probably more than in any other area of concern to labor, personalities have always played a dominant role". Therefore, although short on analysis of on-the-ground activity, Windmuller places the policy-making of American labor at the feet of labor elites yet, fails to address why the Federation's foreign policy goals seemed to line up with the geostrategic aims of the U.S. state.

The expose of American labor activity overseas continued with another flurry of works in the 1970s and 80s. Fred Hirsch (1974) argued that the leadership of AIFLD in conjunction with the CIA played a major role in the coup that removed the democratically elected president of Chile, Salvador Allende, from power on September 11, 1973. Hirsch (42) described the connections between the U.S. intelligence agency and the AFL-CIO as "an infection in the body of labor" and urged the rank and file members of American labor to demand an accounting of current and past practices by the Federation overseas. American support for the Chilean coup has long been established, but the work of Hirsch and Muir (1987) and Scipes (1998) helped confirm that AIFLD was involved with the destabilization campaign that ultimately toppled President Allende and led to the military dictatorship of Augusto Pinochet. 
Other scholars, such as Hobart Spalding Jr. discussed the broader theme of labor "imperialism" in Latin America. In Chile, Guatemala, British Guiana, the Dominican Republic, and Brazil, all countries that experienced U.S. backed or supported coups during the Cold War, Spalding $(1976,57)$ notes significant numbers of foreign unionists being educated by AIFLD, including significant upticks in training enrollment shortly before the Chilean coup. Spalding (63) viewed the educational programs as meeting numerous goals; besides influencing foreign labor leadership, “...it can create teams of labor personnel who can be used against unfriendly regimes as happened in Chile and Guyana" and "[s]econd, through chain reaction it allows U.S. influence to spread among those vast unorganized sectors of the working class." However, Spalding (64) argued that this sort of "imperialism" by U.S. labor abroad was tied into material concerns:

Big labor's past and present foreign policy flows directly from its domestic position. It combats any and all anti-capitalist ideologies. To do this it aids and encourages unions which espouse a pro-capitalist line. It attempts to influence existing organizations and form new ones which will imitate U.S. style unionism. It also supports all governments - dictatorial or otherwise - which take similar stands... The larger the sphere of capitalist influence, the greater the market for U.S. goods and the profits for U.S. companies, both of which strengthen the system at home and therefore, indirectly, U.S. labor... In short, U.S. labor's foreign policy can be summed up in the phrase: what is good for U.S. labor (and capitalism) is good for Latin American labor.

Spalding goes into more detail regarding the tangible relationships between the U.S. state and the AFL-CIO abroad. Citing U.S. Senate reports, Spalding (54) writes that the vast majority of AIFLD funding from 1962-67 came from the U.S. state via USAID, with only around 6 percent of funding coming from the Federation itself and a mere 5 percent 
from business. Interestingly, these ratios are very similar to the Solidarity Center era (see chapter 3).

Scholars and journalists continued to expose details of specific actions of American labor abroad in specific states during this time period. In Brazil, AIFLD trainees helped overthrow the democratically elected government of Joao Goulart and then later helped bolster support for the military regime by training Brazilian unionists in American-style business unionism (Black 1977; Gribbin 1979). In El Salvador the opposite occurred, as AIFLD supported labor organizations loyal to the Duarte government and created parallel unions to undermine more popular labor groups when they refused to follow the U.S. line (Luhan 1986; Smyth 1987a; 1987b). Nathan Godfried (1987) examined the role of the African-American Labor Center's (AALC) trade union education program, noting that it tended to have very little to do with the problems on the ground, and instead focused on collective bargaining and "economism." Godfried (56-7) also details how the AALC in its first decade would only assist "responsible" black leadership in South Africa; that is, labor organizations that focused on bargaining rather than political change. In summation, Godfried (60) writes that “American labour's foreign education programmes have assisted in state and capital activities, both overt and covert, designed to undermine indigenous Third World working class movements."

In 1988, the North American Congress on Latin America (NACLA) devoted an entire issue of their Report on the Americas to AFL-CIO operations in Latin America (Slaney 1988; Spalding 1988a; 1988b). In the NACLA report, Spalding Jr. argues that although the CIO briefly provided a counterweight to the more conservative AFL foreign 
policy, the Taft-Hartley Act of 1947 eradicated the more progressive leadership of the CIO (with its requirement for all officers to take loyalty oaths). With the merger of the two organizations in 1955 the AFL policy line "came to dominate the organization" (Spalding 1988a, 47). Spalding (17) also details how AIFLD initially relied on support from major corporations with interests in Latin America as well as the U.S. state, funding workers' education and social projects to “... build 'free and democratic' Latin American unions..." while at the same time working to “... surreptitiously... undermine labor support for regimes deemed unfriendly to the United States." However, by the beginning of the 1980s, business support was replaced with government funding, and by 1988 AIFLD was operating on a budget supplied almost entirely by the U.S. state. As Spalding (19) notes:

Despite such massive government funding, AIFLD is not a government agency. Under special dispensation, the Institute has been granted status as a private voluntary organization receiving government contracts for specific work. As a result, AIFLD is not subject to congressional oversight nor does it fall under the Freedom of Information Act. Consequently, outside of a few global figures, no public record exists of how AIFLD spends its money. A 1968 congressional investigation found that U.S. AID-AIFLD contracts had been deliberately written in vague terms to allow for maximum flexibility with a minimum of accountability.

Spalding (19) believes this partnership between labor and the state is not totally explained through the "capture" of AIFLD by the U.S. state, but (like Berger, Lens, and others) “...it is perhaps better explained by the rabid anticommunism which dominates the AFLCIO's Department of International Affairs.” In other words, the motivations behind AFL-CIO foreign policy remain opaque even as the logistics of a labor-state relationship are laid bare. 
In a second NACLA article, Spalding (1988b, 22) describes the evolution of AIFLD, noting that as nationalist or left-nationalist governments in Latin America fell to right-wing military dictatorships, AIFLD "reworked its line" in response. However, “[d]espite its modernized stance, AIFLD's energies have not been concentrated on fighting rightwing dictatorships. Rather, like the U.S. government, it has focused on those countries where nationalist or leftwing labor movements threaten the investment climate, particularly the small countries of the Caribbean basin, including Central America" (22-3). Again, the theoretical framework is less than explicit in most of these early exposes, however clear patterns of connections are fleshed out in these works. Among other things, these expose-oriented documents indicate that the AFL and later AFL-CIO foreign policy during the Cold War was heavily dependent on funding and connections with the U.S. state and, at least early on, with U.S. corporate interests. At times the foreign arms of the AFL-CIO also worked directly with/for U.S. intelligence agencies. Finally, the causes of this behavior can be variously attributed to a vehemently anti-communist labor leadership, the principles of business unionism, capture of the foreign arms of the AFL-CIO by state apparatuses, or some combination of all three. Published in 1992, the first comprehensive manuscript aimed at unraveling the different layers of connectivity between Federation foreign policy and the U.S. state was Beth Sims' Workers of the World Undermined: American Labor's Role in Foreign Policy. Sims $(1992,2)$ argues that cooperation between the U.S. state and the AFL (and later AFL-CIO) grew out of World War II and put forth a foreign policy "derived from the ideological biases of a select group of top labor bureaucrats." Sims work is crucial as it goes beyond explaining what the four foreign labor institutes have done in the past, but 
examines the complex linkages between all of the various mechanisms that create the foreign policy of the AFL-CIO and how they were intimately related to U.S. state and business goals during the Cold War. For Sims (22), the partnership between the U.S. government and the AFL and later AFL-CIO was constructed during wartime planning as a tripartite agreement which evolved into a situation whereby “...the international institutes of the AFL-CIO get the overwhelming majority of their funding from the U.S. government, a fact which belies their claim to be private organizations independent of Washington."

Moreover, Sims argues that although the funding patterns shifted over time in terms of agencies involved, the overall funding flows for the foreign agencies of the AFL-CIO involved massive government subsidies. For example, echoing Spalding $(1976,22)$, from 1962-1967 the AFL-CIO received 89 percent of funding through the United States Agency for International Development (USAID). Sims (22) cites a USAID report that acknowledges it has been the "exclusive" supporter of AIFLD for over two decades. Moreover, Sims (like Spalding 1988a) focuses on the lack of transparency within the foreign institutes of the AFL-CIO and details how the organizations are able to overcome requirements on non-governmental funding for "private" organizations. For example, the foreign institutes were able to receive the vast majority of their funding through USAID because they were considered an "intermediary" in carrying out AID programs (Sims 1992, 23). The requirement for a certain percentage of private funding by the U.S. government and the fact that the AFL-CIO institutes were able to avoid them is critical as the "privacy" component was specifically engineered to avoid these organizations operating as "government programs" (23). In other words, Sims points out 
that the AFL-CIO's four main foreign policy programs were specifically exempt from private funding requirements that would have ensured (at least to a minimal degree) some independence from the U.S. state and some degree of transparency in operations.

Sims also sheds light on how funding was distributed and AFL-CIO foreign policy was formulated. Her dissection of funding flows is a critical point, as the difficulty for researchers has always been (and as will be discussed further in chapter 3, remains to be) the opaqueness of the entire foreign policy apparatus of the Federation. Sims $(1992,23)$ notes that "[f]unds from AID flow into the institutes from various sources" and that depending on the grant they reach their destination in a variety of ways. However, "[f]unding from AID is channeled directly to the institutes, bypassing the international affairs department..." which is the AFL-CIO's foreign policy body and where decisions on allocation would have been made (Sims 1992, 23). More to the point, besides the U.S. state financing a majority of the AFL-CIO's foreign programs, “...the institutes receive logistical assistance and feedback on programs from government agencies and U.S. embassies" (26).

Critically, the U.S. state also directed the Federation's institutes to undertake work in certain countries. For example, the White House asked for AIFLD support in Haiti in 1986 to combat "radical" labor unions, and a joint governmental team requested AIFLD assistance in Grenada after the United States invaded in 1983 to "redirect" radical unions (Sims 1992, 26). Finally, "[i]n addition to fielding requests from the U.S. government to work in specific countries, labor representatives participate in government-sponsored interagency meetings to strategize on policy and its implementation" (27). 
Therefore, Sims notes that far from being independent, the AFL-CIO institutes received the majority of their funding from the U.S. state, often intervened directly in certain countries on behalf of the U.S. state, and participated in policy formulation and implementation at high levels. All of this furthers the point that far from a passive role in carrying out its own policy using partial government funds, the AFL-CIO foreign policy during this time period could hardly be considered a "private" endeavor. Rather, a holistic look indicates that the four foreign institutes operated on behalf of and under funding from the American government. Besides being one of the most important works on Federation foreign policy, Sims book also is a loose capstone to the vein of scholarship that saw AFL-CIO foreign activity as being essentially captured by the U.S. state with the approval of anti-communist labor bureaucrats.

With the publication of Workers of the World Undermined, social scientists and journalists as well as labor activists began to publish ever more material on the overseas activities of the AFL-CIO. However, the reviews were mixed on AFL-CIO foreign policy. An article in The Nation described how the AFL-CIO's Free Trade Union Institute (FTUI) was "meddling with the miners" in post-Soviet Ukraine (Siegelbaum and Walkowitz 1992). However, Henry J. Frundt argued that AIFLD activity in Guatemala was showing promising signs of tentative reform. Arguing that despite “...an abiding commitment to capitalist economics, and to its own position as the primary representative of workers within that system", the AIFLD was no longer “...mimicking U.S. imperialist positions..." and was offering a "...freer critique of official political and economic policies" (Frundt 1995, 88). 
Hobart A. Spalding Jr. (1992), continuing his excellent body of work, described an AFL-CIO that was splintering along two different visions of foreign policy; the first typified by AFL-CIO bureaucratic elites and in-line with U.S. foreign policy, the other pushing for a new international vision of labor and organized by rank-and-file workers. In other words, fissions were erupting between the labor bureaucracy that was tied into U.S. geostrategic interests, and union members who questioned the Federation's support for the Contras in Nicaragua, and support of (or at least tactical ignorance of) apartheid in South Africa. Spalding (431) saw these divisions as revolving “....around three issues: Central America, South Africa, and...the question of responsibility on the part of those formulating policy to those whom they purport to represent." In essence, Spalding identified tensions that some scholars attribute to the consolidation of the AFL-CIO's four regional labor institutes into the American Center for International Labor Solidarity in 1997.

The creation of the Solidarity Center brought with it significant scholarship regarding the future of the ACILS, which is covered more fully in chapter three for the sake of coherence. However, before moving on it is critical to point out that even as the debate over a "new direction" for AFL-CIO foreign policy is being hashed out, scholars were still uncovering new information on the four foreign labor institutes of the past and continuing to try and answer the why question in regard to AFL-CIO foreign policy. Using papers from Jay Lovestone and Irving Brown, Anthony Carew (1998) examined the relationship between the CIA and the Free Trade Union Committee (FTUC) in Europe at the beginning of the Cold War. Importantly, Carew's $(1998,25)$ account undermines the assumption of a "...commonplace caricature of a labor movement in the 
pocket of the CIA." Using Carew's work and others (Filipelli 1989; Nack 1999), as well as his own significant volume of research, Scipes (2010, xxii) argues (as discussed above) that labor's foreign policy has been internally constructed and not externally imposed. Scipes (xxiv) puts forth three propositions regarding the nature of AFL-CIO foreign policy over the years:

(1) the foreign policy program of the AFL-CIO (and the AFL before it) tries to dominate foreign labor movements, especially in developing countries, and, therefore is an imperialist foreign policy; since it comes from within the labor movement it should be understood as being labor imperialism; (2) that this labor imperialism began before the Bolshevik Revolution in Russia in 1917, so it was not a reaction to the Bolsheviks, but rather preceded their efforts; and (3) while being designed to advance the interests of U.S. Empire, it comes at the expense of developing country workers and, increasingly, at the expense of American working people ultimately, U.S. labor imperialism also hurts American workers.

Therefore, Scipes' work is engaged, along with most of the scholarship discussed above, in both a descriptive and prescriptive endeavor. However, although the why question is interesting and important, I again must reiterate that in this author's opinion, whether the foreign policy of the AFL-CIO is a product of business unionism, a culture of labor imperialism, or because the structures were controlled by the American state is irrelevant for my research project. The purpose of this work is not prescription, though much of the research is based on secondary sources with a positivist approach. Rather, all of these explanatory modules support the general proposition that will be detailed much deeper in chapter two: that from the end of World War II, the best explanation for the foreign policy of the AFL and later AFL-CIO has been the strategic and economic objectives of the U.S. state vis-à-vis the relationship between the AFL-CIO and the American government. 


\section{SUMMARY OF COLD WAR LITERATURE}

As demonstrated above, the contours of the scholarship regarding the foreign policy of the AFL-CIO during the Cold War do not fit into a "neat" typology due to a consequence of several factors. First, a majority of the scholarship concerning Federation foreign policy was journalistic in nature. That is, much of the detail of what the AFLCIO was actually doing abroad was uncovered piecemeal by journalists and labor activists beginning in the 1960s. Thus, the end result tended to be shorter, detailed pieces on a particular case, more often than not relating to AIFLD and Latin America. Second, a substantial portion of both the expose style accounts and the scholarly literature was overtly programmatic, which limited the theoretical depth and instead focused on prescription. Finally, and most crucially for my research, the major disagreements among scholars, activists, and journalists has been over the why question rather than whether or not the Federation was actively collaborating with the U.S state. That is, the inquiry that dominated the discussion was why the AFL-CIO was engaged in these types of activities abroad? As mentioned previously, this is largely irrelevant for this research project.

Instead, it is crucial to reiterate what a brief look at the scholarship reveals thus far. First, even before the end of World War II, the AFL was actively collaborating with the U.S. state, both overtly through a tripartite agreement with business, and covertly with the precursor to the CIA and later the CIA itself. Second, although this collaboration was not absolute, the vast majority of the scholarship covering the Cold War era indicates a tight fit between U.S. geostrategic goals and the activities of the AFL and AFL-CIO, especially the behavior of the four foreign institutes of the Federation. 
Third, even though only partial records and accounting have been discovered by scholars and journalists, the overwhelming evidence indicates that the AFL-CIO used very little of its own funds in sponsoring the activities of the AFL-CIO abroad. Instead, the vast majority of the funding that has been uncovered indicates that the American government bankrolled Federation operations to a significant degree. Finally, regardless of the explanation put forth by previous works to explain why certain policies were followed overseas, there appears a wide consensus that the AFL-CIO, regardless of motivation, generally acted in a way that supported U.S. geostrategic interests during the Cold War.

\section{CENTRAL PROPOSITION}

My dissertation examines a central proposition: The AFL-CIO has pursued foreign policies whose goals have been closely linked to the strategic and economic objectives most important to U.S. foreign policy bureaucracies, including the State Department, Defense Department, CIA, and the White House. If this central proposition is true, I would expect to find the following:

a- A close fit between the funding flows to the American Center for International Labor Solidarity for their activities abroad and the strategic goals of the U.S. state.

b- Evidence that the Solidarity Center is overwhelmingly dependent on this funding for its operations.

c- Evidence that the Solidarity Center is using this funding to work closely with U.S. allies and coalitions in the developing world. 


\section{METHODOLOGY}

\section{Case Selection}

The American Federation of Labor-Congress of Industrial Organization's foreign policy apparatus, the Solidarity Center, is a good case study for several reasons. The primary reason is that the AFL-CIO has a historical track record of foreign policy involvement well beyond any other labor organization in the United States. A vital component of U.S. foreign policy during the Cold War, the AFL-CIO has been a major player on the international front for over seven decades. Besides the AFL-CIO's history of close collaboration with the U.S. state in both foreign and domestic affairs, it is the largest federation of unions in the United States, consisting of 57 different labor organizations and comprising over 12 million members. Within the AFL-CIO there runs a wide range of unions from both the public sector (such as postal workers and teachers unions) as well as the private sector (including interests as varied as mineworkers and elevator constructors). For all intents and purposes, the AFL-CIO is the U.S. labor organization. Although discussed further in chapter 3, the Federation's rank and file has little knowledge of the activities of the ACILS and has traditionally had little influence over its policies. However, as the evidence from chapter three will indicate, this is not a product of apathy, as numerous resolutions have sought to "open the books", but rather maneuvering by the AFL-CIO to avoid such disclosures.

Further, the Solidarity Center is one of the "core" grantees of the National Endowment for Democracy and one of the major recipients of funding from the United States Agency for International Development and other government agencies. Therefore, 
using the AFL-CIO and its Solidarity Center as the main case study of my dissertation avoids any bias in privileging or picking individual unions (which at various times may have engaged in individual interactions with labor organizations abroad) in certain industries at the expense of others. And, for better or worse, the ACILS is the only labor organization with the sheer scope of influence in foreign policy in the United States. Given its track-record and history regarding the four foreign labor institutes, the AFLCIO's newest foreign policy apparatus is the ideal subject for this study.

\section{Process Tracing and Historical Explanation as Methodology}

To determine whether if the foreign policies of the Solidarity Center can be best explained by its relationship with the U.S. state, my work will utilize the process-tracing method. The method allows the researcher to identify the interactions of different patterns of behavior that can bring to light certain relationships. In the present study, the degree of congruence between U.S. state interests and the policies and behavior of the Solidarity Center can be traced by examining funding flows and comparing them with shifts in U.S. geopolitical aims. The end result allows for an examination of AFL-CIO foreign policy over time which will detail whether the ACILS has pursued foreign policies whose goals have been closely linked to the strategic and economic objectives most important U.S. foreign policy. The method of process-tracing has gained considerable attention in the last 30 years, especially with the publication of Alexander George and Andrew Bennett's Case Studies and Theory Development in the Social Sciences (2005). In terms of this work, the use of process-tracing will provide a nuanced 
look into how changes in union policy can be understood over the last two decades of U.S. foreign policy implications.

Specifically, the method of process-tracing “...attempts to identify the intervening causal process - the causal chain and causal mechanism - between an independent variable (or variables) and the outcome of the dependent variable" (George and Bennett $2005,206)$. In other words, process-tracing is valuable because it allows for researchers to examine numerous co-related variables. As George and Bennett note (206): "[p]rocess-tracing is an indispensible tool for theory testing and theory development not only because it generates numerous observations within a case, but because these observations must be linked in particular ways to constitute an explanation of the case." This is an extremely valuable approach in regard to examining a shift in union policy since singular variables may not adequately describe the entire picture. For example, the Solidarity Center may be spending resources combatting sweatshops and sweatshop-like conditions in a variety of countries. Yet this may only constitute a part of the totality of their work in the long run. However, process-tracing allows for a more holistic examination of the trajectory of union policy to determine whether such occurrences are part of a broader shift away from a strategy of "following the flag" towards a broader vision of labor internationalism by looking at them within a context of funding flows and changes in U.S. foreign policy.

As a work of political science, my dissertation is interested in examining changes over time that focus on causation. Importantly, the end goal is to provide a causal narrative rather than just a depiction of events, which sets process-tracing apart from broad historicism or mere description. Therefore, process-tracing is interested in 
understanding the causal processes at work and “...uses evidence about various features of the decision-making environment, including both the actors' definitions of their situation and the institutional arrangements affecting their attention, informationprocessing and behavior" (Fordham 2002, 3). As Fordham (88) makes clear in his study of NSC 68, the idea of focusing on "unitary actors" leaves much to be desired. In order to grasp the totality of inputs into policy making a more holistic approach is needed; one that can trace out and identify multiple patterns of decision-making and choices in order to shed light on causation.

Therefore, in my dissertation process-tracing is an ideal method because it allows for the examination of numerous independent variables including changes in U.S. strategic goals during and following the Cold War, and in the policies and activities of the AFL-CIO during this same time period. A multi-pronged approach therefore takes into consideration many more variables than studies that rely on a dominant variable to explain causation. Rather than just examining labor elites, or institutional variables, the process-tracing approach in my dissertation will provide a broader narrative focusing on the interplay of numerous factors which can help shed light onto whether the Solidarity Center's strategies share a close linkage with the foreign policy goals of the U.S. state.

Process-tracing is thus an ideal method for in-depth analysis of a small-N study as it allows for consideration of a wide range of independent variables. The materials used in the process-tracing method are varied and also amenable to this work as "...the researcher examines histories, archival documents, interview transcripts, and other sources..." to put together a coherent narrative with which to test the central theory that 
the foreign policy of the AFL-CIO is best explained by its relationships with the U.S. state (George and Bennett 2005, 6).

In reference to this work, these tools will be scrutinizing position papers, budget allocations, and activities of the Solidarity Center as well as military and economic funding by the U.S. state overseas. By using these sources and the specific case study of the AFL-CIO, I will use the process-tracing method to establish relationships among patterns of behavior that connect significant parts of union activity to a broader shift in union foreign policy.

\section{Plan of Dissertation:}

This work will be divided into five chapters in the following pages. This first chapter focuses on the Cold War era literature, research questions, and methodology. The second chapter will be a broad background on the history of AFL-CIO foreign policy as previously researched by scholars, journalists, and labor activists. This chapter will summarize and pull together the activities of the foreign labor institutes during the Cold War and highlight the linkages between the U.S. state and the AFL-CIO with a special emphasis on the creation of the National Endowment for Democracy as a new vehicle for “democracy promotion" activities abroad. Though the second chapter uses secondary sources, it is unique in that it draws in material in a breadth not previously attempted. The third chapter will begin with a focus on the creation of the AFL-CIO's Solidarity Center in 1997, by examining the debates regarding its formation. The bulk of this chapter however, examines broad patterns of funding using NED and Solidarity Center data that highlights linkages between U.S. strategic interests and the ACILS, and 
extrapolates the larger context of these funding flows. The fourth chapter examines three dissimilar case studies: Venezuela, Haiti, and the Middle Eastern/North African (MENA) region with a particular focus on Iraq. The case studies look to explore whether the ACILS is aligning with U.S. allies and coalitions in their operations overseas. Finally, the fifth chapter will assess whether the case studies from chapters three and four indicate continuity or change in the policies of the Solidarity Center in contrast to the pre-ACILS era, and also place this research into a broader debate over the power of NGOs in relation to the state. 


\section{CHAPTER II.}

\section{FEDERATION FOREIGN POLICY DURING THE COLD WAR}

The present study examines whether or not the foreign policy of the AFL-CIO is best explained by its relationship with the U.S. state in the post-Solidarity Center era. And, flowing from this proposition, it is necessary to explore the mechanisms that enable the relationship between the AFL-CIO and the U.S. state. As described in the literature review in the previous chapter, the explanations of AFL-CIO foreign policy has often revolved around sometimes competing and other times overlapping frames of reference, including anti-communism, internal AFL-CIO politics, and the fundamental underpinnings of business unionism. My dissertation argues that all of the above played influential roles and, at different times, took the lead role in structuring AFL-CIO activities abroad. However, the determining factor in understanding AFL-CIO foreign policy has been the exigencies of the U.S. state.

Thus, the purpose of this chapter is to provide an overview, consisting of mainly secondary sources, that highlights the linkages between the AFL-CIO and the strategic and economic objectives of the U.S. state during the Cold War. The use of secondary sources here is both necessary and constructive. Necessary, because of the lack of transparency within the foreign policy apparatus of the AFL and AFL-CIO during the Cold War (and indeed to this day), and constructive, as few, if any, scholars have focused on such a broad sweep of Federation foreign policy in this manner. Therefore, though many of the cases described in this chapter are originally attributable to other scholars and journalists, this (to my knowledge) is the first time they are being brought together in 
a manner that differentiates between "stabilization" and "destabilization" and attempts to cover a significant number of regions and activities.

To preview, this chapter briefly links AFL foreign policy under Samuel Gompers to a broad commitment to anti-communism, business-unionism, and U.S. geostrategic aims in Mexico in the early $20^{\text {th }}$ century. Later, this cooperation expanded when labor elites partnered with the U.S. state and corporate interests during World War II under a tripartite agreement to maintain wartime production. At the end of World War II and the outset of the Cold War the relationship between the U.S. state and labor deepened, largely due to the consolidation of power by vehement anti-left labor leaders such as George Meany, Jay Lovestone, and Serafino Romualdi in regard to foreign policy. Eventually, AFL-CIO foreign policy shifted along with the U.S. state from a commitment to anti-communism to more nuanced "democracy promotion" activities abroad. In this section, the mechanisms of "democracy promotion" are analyzed and tied into the activities of the Federation from the early 80 s to 1997 . Finally, the common thread that dominates this narrative during the Cold War is explored: the support by the AFL-CIO for the geostrategic goals of the U.S. state in the developing world. For example, the AFL-CIO followed the objectives of the US state in supporting apolitical unions in countries that were friendly to US foreign policy goals. In countries considered to be enemies of the US state, the AFL-CIO linked with oppositional unions that took explicit political positions against their governments. 


\section{Gompers and the Early Roots of AFL Foreign Policy}

The foreign policy of the federation has a long history, dating back to the late 19th century, well before the AFL and CIO merged to form one labor organization in 1955. Prior to the Cold War and the intimate ties between the U.S. state and the AFL-CIO, the AFL's first head, Samuel Gompers, brought the Canadian Trades and Labor Congress into the fold in 1902 as a state delegation (Babcock 1974). However, Gompers first real attempt at international organizing came with the creation of the Pan-American Federation of Labor (PAFL). The PAFL was created with the direct help of the U.S. state via $\$ 50,000$ in 1918 “...from the President's special fund...” (Berger 1969, 47). The PAFL was ostensibly created to develop Latin American trade unions, however in actuality it functioned more as a political organization concerned with constraining the perceived threat Germany posed to American interests in the region. In fact, Gompers described the PAFL as "based upon the spirit of the Monroe Doctrine," in reference to the American policy that claimed the Western Hemisphere to be the "backyard" of the United States (Sims 1992, 37). Gompers' preoccupation with Germany shortly transformed into fear of an even larger threat by 1919, with the Bolshevik Revolution in Russia. As a former socialist himself, Gompers' spent a good part of the rest of his life fighting against alleged communist encroachment, often using organizations such as the PAFL as the vehicle (Toth 1967).

Thus, Samuel Gompers personality and predilections greatly influenced AFL policies both within the United States and abroad. As Scipes writes, citing Louis Reed's work on Gompers, “....any interest within the AFL about foreign affairs was almost always initiated by Gompers or at his behalf” (Reed 1930; Scipes 2010). Therefore, 
under Gompers, the AFL's foreign policy was inextricably linked to his business unionism worldview. The Federation with Gompers at the helm supported American interventions abroad and economic expansionism, stopping just short of colonialism (Andrews 1991; Scipes 2010). It is crucial to note that this did not mean Gompers and the AFL were mere agents of the U.S. state. Rather, as Gregg Andrews (1991, 197) points out in his comprehensive study of the AFL and the Mexican Revolution, Gompers and the AFL sought out U.S. state legitimization and assistance, but did not always act in congruence with the American government: "[a]lthough Gompers in general favored a less confrontational approach to successive revolutionary governments in Mexico and often defended those governments against U.S. attempts to dictate Mexico's internal policies, he quietly endorsed the military interventions undertaken by President Wilson.” However, Andrews $(1991,199-200)$ also makes clear that AFL activity in Mexico during this time period laid the ground work for increasing synergy between the U.S. state and organized labor in the years to come:

The AFL's response to the Mexican Revolution later made possible the growth of tripartite structures designed to maintain U.S. hegemony in Latin America. Gompers had consistently sought a consensus of big business, labor and government... Nevertheless, American officials and capitalists who sought to preserve the long-range strategic and economic relationship with Mexico through financial diplomacy and less confrontational means had a favorable view of the AFL's policies in Mexico. This would have greater significance after World War II, when international bankers, multinational corporations, and U.S. officials conceded a more aggressive role for organized labor in foreign policy.

Therefore, in these early days of AFL foreign policy it is clear that the Federation did not act as an agent of the U.S. state in all its endeavors. Rather, there was considerable debate and disconnect between the American government and the AFL in regard to 
tactics and methods. As discussed in the introduction, this has led some to argue (Andrews 1991; Scipes 2010) that the policies of the AFL and later AFL-CIO were in fact born internally in the labor movement. However, just because there was some tension in the early years of AFL foreign policy does not change the fact that the Federation's goals were largely in-line with the American state. Though the collaboration between the Federation and the U.S. state were just in their infancy at the end of World War I, during World War II and the Cold War this partnership would develop into a more symbiotic relationship, involving a web of funding flows and linkages. It is to the evolution of this relationship we now turn.

\section{The Institutional Evolution of the Labor-State Relationship}

In broad strokes, there has been an evolution over time in the levels of connectivity between the Federation and the U.S. state. Beginning with the founding of the ill-fated PAFL in 1918 and Gompers' push to have the AFL considered a serious partner in American foreign policy in the early $20^{\text {th }}$ century; organized labor's foreign policy became more and more entrenched with the U.S. state in regard to funding and direction. As mentioned above, although there was some synergy between the U.S. government and the AFL early in the $20^{\text {th }}$ century, it is during the interwar period that the Federation and the American state increased their ties significantly. By the beginning of World War II, the AFL was uniquely positioned to be an active participant in U.S. foreign policy. As Beth Sims $(1992,38)$ notes, although the CIO and AFL both maintained offices in Europe and conceivably had the ability to work with the U.S. state “...it was the more conservative AFL that was closely tied to Washington both politically 
and financially." Therefore, it was the AFL and not the more (at the time) radical CIO that moved into the breach of war-torn Europe during the Second World War. As is discussed below, this made a lot of sense given the prevailing political climate in the U.S. in the post-war period. By 1947 the CIO would have its leadership positions hamstrung by the Taft-Hartley Act's "loyalty oath" provision.

During the first decade of the Cold War, (roughly until the merger of the AFL and CIO in 1955), labor operations overseas formed an intricate web of interlinking connections between the U.S. state, its intelligence agencies, and a variety of AFL supported organizations. Until the formation of the American Institute for Free Labor Development (AIFLD) in 1962, the Federation used a variety of funding flows, including direct injections of cash from the CIA, to fund operations in Europe, Asia, and Africa. However, beginning in 1962, these relationships became more solidified with the addition of AIFLD which was followed shortly by the creation of the African American Labor Center (1964), the Asian American Free Labor Institute (1968), and the Free Trade Union Institute (1977). These four regional institutes gave structure to AFL-CIO foreign policy and were deeply embedded with the U.S. state, receiving the vast majority of their funding from USAID and later the National Endowment for Democracy.

The foundation of these relationships involved numerous overlapping factors: the business-unionism tendencies of the federation and the symbiotic relationship whereby labor "followed the flag" abroad in exchange for material benefits to American workers at home, as well as a zealous cadre of anti-communist labor lieutenants who formed much of the leadership of the Federation, especially so in foreign policy quarters. Added to this is the absolute secrecy of the Federation's activities abroad during the early part of 
the Cold War. In fact, it is not until the early 1960s that journalists and labor activists begin to uncover the tangled web of activity that the AFL was engaged in overseas. Thus, taken as a whole, the rising tide of prosperity mixed in with a vehemently anticommunist labor leadership operating without rank-and-file accountability meant that throughout the Cold War the U.S. state and American labor became increasingly intertwined.

A critical look at the policies of the AFL-CIO both at home and abroad indicates that the strategies pursued during the Cold War were in many ways linked to a historical era of rising wages, benefits, and overall economic growth. In other words, the business unionism model was "working" for several decades following World War II in bringing organized workers the spoils that they desired. Of course, this argument ignores much of American society that was either in an unorganized industry or lived in a region hostile to unions in general, such as the South, or suffered from racist policies of exclusion. Regardless, it is critical to note that there was a material explanation for the foreign policy of organized labor in the United States in the post-war era, especially up until the early 1970’s.

The end of World War II saw a confluence of factors encourage business union federations like the AFL-CIO to believe they were in the ascendance. First, much of Europe and Asia lay tattered in ruins with its industrial output either seriously diminished or totally destroyed. At the end of the war, the United States was producing some $60 \%$ of the goods put out by industrialized countries and $40 \%$ of all goods and services consumed worldwide (Ferguson and Rogers 1986, 49). The post-war boom in the United States led to an era of economic growth and opportunity for workers made possible by the passage 
of the National Labor Relations Act (NLRA) in 1935, which formalized the process by which workers could organize and assert their power. In fact, immediately after the war organized labor flexed those new-found muscles when some seven and a half million workers went on strike between 1945 and 1946 alone (Moody 2007, 64). Membership in U.S. unions was rising, from 6.5 million in 1939 to over 12 million by 1945 . Alongside these trends of higher wages and guaranteed benefits and pensions, millions of bluecollar Americans bought their first homes and sent their children to universities. Typified by what was deemed "The Treaty of Detroit", where the United Auto Workers and General Motors agreed to a five-year contract in 1950, organized labor was able to secure long-term contracts with capital in many industries (Goldfield 1987, 46). Thus, for many organized workers, this sort of contractual agreement seemed to be the model upon which workers and owners could build a mutually beneficial future.

While this strengthened business unionism at home, it also allowed the AFL-CIO to collaborate with the U.S. state in the post-war environment. The relationship between the Federation and the U.S. state was constructed largely through the efforts of Nelson Rockefeller, who headed the State Department's Office of Inter-American Affairs during World War II (Sims 1992, 10). As Beth Sims (10) notes in Workers of the World Undermined, Rockefeller encouraged the creation of a labor-business-state coalition that initially sought to coordinate wartime production and aims. However, in the post-war context this relationship became more and more intertwined as organized labor's activities abroad complemented business interests and state goals in dealing with the developing world. 
As American workers reaped the economic benefits of the post-war world, the beginning of the Cold War divided that same world into two opposing camps as the competition between East and West took on an all-encompassing importance. In 1947 the Truman Doctrine proclaimed that the U.S. would use both military force and economic assistance to prevent Greece and Turkey from entering the communist sphere of influence. In 1950, the strategy of communist "containment" became the watchwords of U.S. foreign policy, as Paul Nitze's (National Security Council [NSC] 1950) influential NSC 68 argued that "[t]he issues that face us are momentous, involving the fulfillment or destruction not only of this republic but of civilization itself" (NSC 1950). NSC 68 went further, explaining that the Soviet Union intended to use every means available to subvert democracy and that "[t]he Kremlin design seeks to impose order among nations by means which would destroy our free and democratic system" (Ibid.). As NSC 68 makes clear, this was often presented as a fundamental ideological battle with no middle ground. Moreover, as Guilhot $(2003,33)$ argues, “...the United States framed its opposition to Soviet policies not in terms of divergent interests (for different interests are equally legitimate from a moral point of view) but in terms of a radical opposition between two models of civilization and value systems, between democracy and totalitarianism." Framing American-Soviet tensions in these terms would have consequences for the American public, policymakers, and partners in U.S. foreign policy; like the AFL and later AFL-CIO during the Cold War.

Thus, nationalism became part and parcel of the U.S. labor movement at the highest level, and worked its way down to rank-and-file workers. The USSR was not just the enemy; it was an insidious and opaque force, aiming for nothing short of the 
destruction of democracy and freedom. Therefore, it is no surprise that the political backlash against communist-led or even moderately leftist unions was swift and severe. American unions, especially those affiliated with the CIO, saw massive purges of leftists, both alleged and actual, not only on the command of conservative trade union leadership, but also through legislation. The Taft-Hartley Act of 1947 demanded that all union leaders submit an affidavit that they were neither communist nor sympathetic to communism (Rayback 1959, 399). Failure to do so would mean the loss of all the legal protections enshrined in the NLRA for labor unions. Thus, as anti-communism as an ideology ramped up, labor unions were often a prime target as their membership was likely to include some radicalized elements. As Kim Scipes $(2010,28)$ notes, communist infiltration did not have to be specific or detailed, as “...[i]t has not mattered if that person was a member of a communist party or just a militant trade unionist: a broader vision, militancy, and especially willingness to engage in more than negotiations for collective bargaining agreements, have long been seen as signs of communists."

With the removal of many of those who would oppose the business-unionism policies of the Federation, the stage was set for labor to follow the flag. In most cases, labor elites were only too happy to oblige. AFL-CIO President George Meany (and later Lane Kirkland), wrapped up their business unionism ideology in Cold War rhetoric and ensconced it in patriotism. Thus, the beginning of the Cold War and the rise of anti-left sentiments in the United States reinforced the strength of business unionism as a modus operandi for American labor domestically, while at the same time the AFL-CIO became a partner in U.S. foreign policy implementation abroad. Labor elites saw the developing 
world through the lens of both Cold War politics and domestic economic interests: good to beat the Soviets, better still if it meant that workers at home reaped the benefits.

Finally and possibly most critically, added into this mixture was a layer of labor bureaucrats, removed from the rank-and-file Federation members who were more than willing to act under the world-view posited by the theories laid out in NSC 68. Although AFL leaders George Meany and later Lane Kirkland were both die-hard Cold Warriors with intimate ties to Washington, the men they chose to head up and operate the Federations foreign affairs during the Cold War were a particular breed of anticommunist. As Nicolas Guilhot (2005) lays out in his excellent work The Democracy Makers, the most vehement critics of the USSR during the Cold War were often culled from a most interesting source: former communists. It was the anti-Stalinist, often Trotskyist, Marxists who were often ahead of the curve in their denouncements of the Soviet Union, and who would later form an integral part of the democracy promotion program that re-shaped American foreign policy in the 1980s. Thus, "[p]aradoxically, while the non-Communist left represented a marginal political force that still considered itself part of the revolutionary tradition, it became the very social foundation of the main anticommunist strategies articulated by the State Department and the CIA in the late 1940s" (Guilhot 2005, 37-8).

One of the most prominent examples is that of Jay Lovestone. A former member of the Communist Party, Lovestone was expelled in 1930 and spent the rest of his life attacking perceived communist infiltration in all quarters with an almost religious zeal. Lovestone would play a major role in the Free Trade Union Committee operations in 
Europe, and hold prominent positions in the Federation foreign policy apparatus. As Guilhot (2005, 38-9; Muravchik 2002, 252-3) notes:

George Meany, the violently anticommunist boss of the AFL, and Lovestone seemingly managed to convince State Department officials of the crucial importance of labor in the confrontation with international Communism, and to have numerous 'Lovestoneites' appointed as labor attaches in U.S. embassies, while the FTUC benefited from CIA funds for its operations.

Lovestone may have been the most prominent former leftist to join forces in the fight against communism; however he was by no means the only one. Other extreme anticommunist figures in Federation foreign policy during this time period included Matthew Woll, Irving Brown, and David Dubinsky (Sims 1992, 38). These names surface time and again when researching the activities of the Federation abroad, and formed the backbone (along with George Meany and Lane Kirkland) of the AFL and AFL-CIO foreign policy apparatus. These men also argued for the inclusion of labor in the struggle against totalitarianism in labor publications, in essence pulling and pushing labor in a direction that fell in line with American foreign policy. Guilhot $(2005,41)$ emphasizes this, writing that " $[p]$ reviously implicit in the denunciation of totalitarianism, anticommunist motives became more explicit and more pressing, and they were used as a powerful rationale for the involvement of labor in international politics."

Thus, the previously mentioned combination of factors placed the Federation in a unique position to align with the U.S. state in foreign policy matters. First, the material benefits brought home to organized labor in the wake of World War II meant that business unionism as an ideology seemed to be working for the rank-and-file, and intimated that a true tripartite relationship was desirable. Second, the domestic pressure 
placed upon society in general, and labor in particular, to expel perceived or real leftist influences decimated the ranks of the $\mathrm{CIO}$ and thus doubly strengthened the position of the more conservative AFL. Primarily, the AFL benefitted from the disorder caused by CIO expulsions. However, an added bonus for the AFL was that by the time of the merger, the AFL dominated the newly combined labor body, including in foreign policy matters. Third, the shift of U.S. foreign policy from a strategy of coexistence to one of "containment", replete with the need to battle the USSR on all fronts, including labor, meant that the AFL was in prime position to ally with U.S. foreign policy. Finally, this partnership was ushered along with the help of a cadre of vehemently anti-communist labor elites, from Meany on down.

\section{The Federation Foreign Institutes: A Primer}

Before delving into the case studies, it is important to briefly describe the foreign policy institutes of the Federation, as the vast majority of stabilization and destabilization campaigns described in the following section occurred under the auspices of one of these four foreign policy arms. As briefly mentioned before, during the Cold War the AFLCIO conducted its foreign operations through these regional institutes which were set up over a period of 15 years. These institutes were charged with coordinating activities, finding and funding projects, and maintaining the presence of the AFL-CIO abroad. The Federation operated through ad-hoc organizations and the Free Trade Union Committee (FTUC) at the tail end of World War II, while at other times utilizing larger global and regional labor federations such as the Inter-American Regional Organization of Workers (ORIT). For example, the AFL-CIO worked through ORIT (the regional organization of 
the staunchly anti-communist and AFL-CIO-backed International Confederation of Free Trade Unions (ICFTU) founded in 1949) in Latin America in the early 1950s. Eventually, the Federation would move towards creating foreign policy structures organized by region that were only loosely, if at all, tied into international labor federations like the ICFTU, the World Federation of Trade Unions (WFTU), and the World Confederation of Labor. Even the largest global labor association, the International Labor Association (ILO), which was founded in part by Samuel Gompers and based on the tripartite theory that underlies business unionism, had little sway with the AFL-CIO. During the Cold War the Federation used these organizations as a platform, but was not above creating and using their own institutes to further policy. The Cuban Revolution's triumph in 1959 was a watershed moment, not only for American foreign policy, but for the Federation's contacts and organization in the region. For the AFL-CIO and the U.S. state, the rise of the Castro regime indicated a new need for a stronger response to communist encroachment in the United States" "backyard." It did not help that members of ORIT might have been sympathetic to the Cuban Revolution. One part of this response was the creation of the American Institute for Free Labor Development (AIFLD), which in 1961 became the first "labor institute." In a report to the Senate Committee on Foreign Relations, the creation of AIFLD was deemed "primarily a response to the threat of Castroite infiltration and eventual control of major labor movements within Latin America" (Herod 2001, 143). Andrew Herod further cites the report, writing AIFLD's stated goals were two-fold. Specifically, AIFLD (Herod 2001, 143) was to: 
...provide necessary training to members of democratic trade unions in order to develop their organizations as responsible, free, and democratic unions and to install in the leaders the qualifications required to develop and maintain organizations dedicated to social and economic development; and to administer and conduct a program of labor leadership training and/or labor leadership seminars.

More to the point, AIFLD was initially conceived of as a partnership between labor, business, and the U.S. state. The AFL-CIO joined with Rockefeller and the Grace Corporation in founding AIFLD as a "non-profit institute administered by the AFL-CIO, but backed as well by 60 US business firms, and the U.S. government, which finances or guarantees about 80 percent of its program" (Scipes 2010, 32). Further, AIFLD became the labor arm of President John F. Kennedy's Alliance for Progress, a program aimed at fostering development and support for the West in Latin America.

While the broad mandate of AIFLD was to assist democratic unions and help educate unionists in the region, in actuality the organization acted much more as a subtle wing of U.S. foreign policy during the 60's, 70's, and 80's. Thus, AIFLD's main focus was to "supplant left-led unions with better funded pro-American and pro-business unions" (Buhle 1999, 151). As the evidence demonstrates, more often than not AIFLD was involved in maintaining and creating union apparatuses in Latin America that were friendly to U.S. capital, dominant political and economic elites, and subservient to U.S. policy goals in the region. To be sure, AIFLD was undoubtedly involved in campaigns that did not involve details such as those discussed below, however the historical research indicates that these activities alone seriously undermine the idea that the institute was acting as an independent agent promoting "democratic" trade unions. In Brazil, Chile, British Guiana, the Dominican Republic, El Salvador, Guatemala, Haiti and Nicaragua, 
AIFLD was actively involved in either destabilizing regimes that were considered hostile to U.S. interests or in helping to stabilize authoritarian regimes that were considered allies by the U.S. state.

Though scholars and researchers have not given as much attention to the other AFL-CIO foreign institutes, what has been uncovered indicates similar patterns of subservience to U.S. foreign policy goals and geostrategic interests during the Cold War. Founded in 1964, the African American Labor Center (AALC) worked to tirelessly undermine left unions in Africa during the Cold War, especially in South Africa, Kenya, Nigeria, and Angola. Led by labor attaché and CIA operative Irving Brown, the AALC was tasked with “...funneling U.S. aid to procapitalist, economistic African trade unions" (AALC 1974; Meisler 1969; Sims 1992, 57). The AALC built labor colleges, funded and created parallel unions, published four separate newspapers, as well as other activities in over 33 countries between 1965 and 1974 alone (Godfried 1987, 55). As was the case in Latin American and the Caribbean, the primary goal (besides anti-communism) of the AALC was to direct African labor organizations to focus on economism, collective bargaining, and labor-management relations. In Africa, however, this dependence on collective bargaining took on a new "cultural" focus:

Collective bargaining according to the AALC, grew out of traditional African practices. 'African Traditions and Trade Unions,' a 1971 film written by Nate Gould, principal of the Ghana Labour College (and later the AALC's representative in Nigeria), and produced by the AALC, linked together 'the ancient African art of negotiation and compromise to the modern trade union techniques of collective bargaining and arbitration... Regional Director John Gould correlated African labour's lack of workers' rights to the weak state of collective bargaining on the continent. 'It is through collective bargaining,' explained Gould, 'that rights are established' (Godfried 1987, 56). 
Possibly because of this paternalistic approach, the AALC often had trouble creating authentic linkages with African labor organizations and leaders. In response, in 1967 the AALC created the African-American Consultative Committee, which remained a largely perfunctory body as the programs were still "...formulated and implemented by the AALC's executive staff in New York and its approximate fourteen technical advisors in Africa" (Godfried 1987, 54). However, the AALC often termed its approach to African trade unions in this demeaning manner, for example, Irving Brown, in meeting with South African unionists in 1973 expressed his opposition to a "violent change to apartheid" and that assistance would be available only to "responsible black leadership," which needs no explanation (56). Therefore, the AALC operated much in the same manner in Africa as did AIFLD in Latin America, focusing workers on economism and attempting as much as possible to divert resources and energies away from politics, especially politics of the left.

In 1968, the AFL-CIO created the Asian American Free Labor Institute (AAFLI) with the specific direction of working in Vietnam, after the AFL-CIO became dissatisfied with opposition to the war by many members of the International Confederation of Free Trade Unions (ICFTU) as well as the growing influence of social democrats within the organization. Activity like this followed a pattern, as the other institutes, in some way grew out of dissatisfaction with international or regional labor organizations and their membership or policies. There were other similarities too, including links with the CIA, as former CIA agent Phillip Agee declared the AAFLI to be filled with "principal CIA agents" (Agee 1975, 616; Sims 1992, 60). During its existence, the AAFLI operated in over 30 countries in Asia, the Pacific, and Middle East and often collaborated with 
government approved workers organizations at the exclusion of all others. In countries like the Philippines and South Korea, this often meant supporting both unions and regimes that were notoriously corrupt and repressive of labor (See Scipes 2010; Shorrock and Selvaggio 1986; Sims 1992).

The AFL-CIO's last regional institute, the Free Trade Union Institute (FTUI), was created officially in 1977, but in was basically a resuscitation of the FTUC which had fallen dormant following the end of World War II. Regionally oriented toward Europe, the FTUI achieved its greatest success with its significant funding of Poland's Solidarity movement, however it was also noticeable for becoming the vehicle for which all USAID and NED funding was passed on to the other three regional institutes (Sims 1992, 54). However, the FTUI became especially relevant in the former Soviet bloc at the end of the Cold War as privatizations and "shock therapy" became the dominant themes of U.S. foreign policy.

Thus, these four foreign institutes evolved to become integral parts of Federation foreign policy between 1961 and 1977. In the following sections I move from the broad contours to the specific examples that illustrate that during the Cold War, Federation foreign policy is best explained by the exigencies of the U.S. state. Though these activities took place via different bodies (for example the FTUC which received direct CIA funding as contrasted with AIFLD that received a majority of its funding from USAID), over time a pattern emerges that establishes a direct relationship between the foreign policies of the AFL-CIO and the geostrategic policies of the U.S. state. In cases where the AFL-CIO dealt with a "friend' of the U.S. state, the federation operated under principles of business unionism, encouraging apolitical activity by foreign labor 
organizations and focusing on legal mechanisms such as collective bargaining to stabilize client regimes. However, when confronted with an "enemy" of the U.S. state, the Federation did exactly the opposite, encouraging unions to mount political campaigns to destabilize unfriendly governments.

\section{The AFL and AFL-CIO \& the Cold War: Stabilization}

The first labor-state foreign policy collaboration during the Cold War period was a by-product of the Allied response to Nazi Germany and the Axis powers. Much like Gompers' PAFL, the Free Trade Union Committee (FTUC) was created by the AFL to shore up labor organizations in Europe combating fascism. However, the FTUC mission quickly evolved into that of an anti-communist umbrella organization. As Kim Scipes (2010,31) notes, “[t]his 'retargeting' took place before the war's end, while the U.S. was still allied with the Soviet Union against Hitler's Germany." At its earliest stages, the FTUC “...had a loose and conveniently ambiguous relationship with the AFL. At one level it was an informal clearinghouse for AFL business which might later be formally approved by the Federation's International Affairs Committee. Yet more often than not it was where key decisions were actually taken" (Carew 1998, 25). By 1948, the FTUC received its funding for these operations, meant to stabilize European regimes against communist influence, directly from the Office of Policy Coordination, which would be absorbed directly into the CIA in 1950 (Ibid.). Importantly, the International Affairs Department and the FTUC was staffed by militant anti-communists such as Matthew Woll, David Dubinsky, and Jay Lovestone, and “...financed organizing and propaganda activities, selected candidates to lead foreign unions, financed their campaigns, paid off 
supporters, and helped build pro-western union infrastructures" (Sims 1992, 38-9). In short, the FTUC provided the framework for the raison d'être of the Federation's foreign policy during the Cold War. Critically, the Federation began a long affair with the use of "parallel" unions; that is creating unions that could vie for support, as well as poach members from larger, more powerful labor organizations that harbored leftist sentiments, whether real or imaginary.

Thus, the FTUC funded and organized the "Workers Force" (Force Ouvriere) in France with disaffected members of the General Confederation of Labor (CGT) because of communist influence within the CGT. In Germany, the Federation based its connections upon anti-Soviet stances rather than on whether or not labor organizations had stood against Hitler. Similar patterns repeated themselves in both Italy and Greece, where the litmus test for FTUC funding and approval became not workers' rights or interests, but militant anti-communism (Cantor and Schor 1998, 35; Sims 1992, 39). The range of the FTUC's activities was not confined to Europe. An office was maintained in India, Tokyo, Indonesia, and by 1950 “...substantial sums began to be channeled to China where FTUC representative Willard Etter, based in Formosa, financed the Free China Labor League with its training program in espionage and sabotage for agents infiltrating the Chinese mainland" (Carew 1998, 26).

As Anthony Carew $(1998,25)$ makes clear in his work on the FTUC, from approximately 1949 to around 1958 “...this semi-independent AFL body became highly dependent on CIA finance while providing the agency valuable cover and additional sources of intelligence on communism abroad." However, the coordination between the FTUC and the CIA was not exact. Although the CIA funded the FTUC and used it for a 
variety of intelligence gathering operations, there were organizational and personal rivalries that developed in the course of the relationship that ultimately led to a diminishment of CIA funding for the institute. Carew identifies at least three issues that began to cause fissures in the FTUC-CIA marriage. First, issues began to arise with the accounting of funds, especially in regard to the Italian labor organizations, which the FTUC believed was given too much money by the CIA directly and thus undermined FTUC influence. Second, the CIO began operating in Europe, and therefore challenged the hegemony of the AFL (and thus the FTUC) on the continent. And finally, some of the CIA brass had reservations about the true allegiance of the former communists, like Lovestone, who made up much of the FTUC ranks (Carew 1998). The relationship continued south from 1950-52, and the funding the CIA allotted to the FTUC was indicative of such, as it dropped significantly each year, from a high of $\$ 172,882$ in 1950 to $\$ 96,060$ in 1952 , and finally bottoming out at just $\$ 10,109$ in 1958 (Carew 1998, 33). Unfortunately, a broad-based accounting of funding is not available and therefore it is unclear exactly what the CIA funding patterns looked like. However it is assumed that these "donations" formed a sizeable percentage of the FTUC budget. The lack of transparency within Federation foreign policy is discussed throughout this work, especially in the latter portions of the present chapter and chapter three.

Regardless, the linkages that directly tied the CIA and FTUC had their origins in the historical context of the Cold War. The Office of Policy Coordination, which was merged with the CIA in 1950, initially used the FTUC as go-between in dealing with labor organizations that could help combat Soviet and communist influence in Europe (Carew 1998). However, this was not a neat synergy between organizations. The CIA 
controlled much of the bankroll of the FTUC, especially during the early years, but did not enjoy total control over the organization as disputes over personnel, spending, and personalities lead to a sometimes frosty arms-length relationship. For our purposes we are interested in the broad contours of state-labor collaboration and how this initial coordination led to more fundamental collaboration as the Cold War progressed (for good overviews of this quasi-partnership see Carew 1998 and Waters and Daniels 2005).

Paul Buhle $(1999,140)$ describes these early exploits of the Federation in Europe in even more color:

In some places, Communist-led strikes would be broken by criminal elements directly in AFL employ or allowed to practice their trades unhindered as quid pro quo; alternatively, where Communist or nonCommunist radicals perceived as anti-American had been elected to labor officialdom or public office, strikes would be "arranged" for maximum chaos. Pushing their own candidates for union elections and general elections, the conspirators quickly filled a vacuum of resources in hungry Europe. Most often choosing reliable Catholic conservatives, Lovestone's partners in a pinch were best remembered as erstwhile supporters of fascist regimes whose officials were now being quietly protected as CIA assets, including some well-known heroin traffickers.

Critically, not everyone believed that the CIA-FTUC partnership, with its cloak and dagger exploits and secretive nature was a bad thing. On May $20^{\text {th }}, 1967$, The Saturday Evening Post ran an op-ed by Thomas W. Braden entitled "I'm Glad the CIA is 'Immoral'." Braden (1967), a former CIA operative had recognized his own code name in a NY Times piece criticizing CIA and FTUC actions in 1950 and argued that "... surely it cannot be 'immoral' to make certain that your country's supplies intended for delivery to a friend are not burned, stolen, or dumped into the sea." Braden was referencing the 
payments made by the CIA via the FTUC to French dockworkers to unload American supplies.

Most importantly, Braden's patriotic appeal to his role as a CIA agent working with the Federation's overseas operatives goes on to highlight some intriguing aspects of American labor's activities abroad throughout the Cold War (and possibly today even after the creation of the Solidarity Center). As Braden (1967) writes:

The money we spent was very little by Soviet standards. But that was reflected in the first rule of our operational plan: "Limit the money to amounts private organizations can credibly spend." The other rules were equally obvious: "Use legitimate, existing organizations; disguise the extent of American interest: protect the integrity of the organization by not requiring it to support every aspect of official American policy."

Braden (1967) also unintentionally foreshadowed the patterns of U.S. funding for overseas labor activities under the NED and USAID (discussed later and in chapter 3): "[a]s for the theory advanced by editorial writers that there ought to have been a Government foundation devoted to helping good causes agreed upon by Congress-this may seem sound, but it wouldn't work for a minute."

The FTUC was unofficially disbanded in December 1957, after the merger with the CIO created an internal struggle between Reuther and Meany, a battle which the Meany-wing would eventually win, yet the Federation's role in foreign policy was far from finished and the strategy for the AFL-CIO in terms of its relations with the U.S. states were already firmly in place. With the merger of the AFL and CIO into one body in 1955, organized labor's anti-communist agenda was solidified as the AFL-CIO's first president, George Meany made clear in his first address on foreign policy issues. Stating that there were no neutrals in the struggle between the communist bloc and democratic 
nations, Meany would continue the Gompersian support for undermining communists around the world (Windmuller 1956). As Windmuller $(1956,420)$ points out, even before the merger both federations incorporated more than just words into their foreign policy positions, spending approximately 10 percent of their respective budgets on the matter. However, after the two federations joined forces their foreign policies would become more intertwined with the Cold War and U.S. state interests than ever before. This dedication to foreign affairs and cultivating and encouraging "free" trade unions even found voice in the Federation's Constitution, which states in Article II, Section 7 that part of its duties are to "...give constructive aid in promoting the cause of peace and freedom in the world and to aid, assist and cooperate with free and democratic labor movements throughout the world" Within Article II, Section 10, which has been since removed and/or amended, the constitution initially mentioned an obligation "to protect the labor movement...from the undermining efforts of Communist agencies" (U.S. Const, 422).

After the FTUC was left to atrophy in 1957, the Federation engaged in a significant number of foreign activities designed to stabilize client regimes of the United States. In Brazil, following the 1964 coup, the Federation worked with the military dictatorship even as the new regime worked to repress the power of labor. The largest Brazilian union during President Goulart's short-lived term, the General Workers Command (CGT), was “....abolished after the coup and some 409 unions, 43 federations, and 4 confederations were taken over by government interventors" (Black 1977, 118). The military regime revised the Labor Code to exclude members of the CGT from “...holding office in economic or professional organizations" and sought to reorient 
union activity towards “...moral and civic education” (Ibid.). Over the following five years, the coup leaders cut wages, and by 1970 had limited strike activity to basically zero (Spalding Jr. 1988, 20). Although the AFL-CIO would admit in 1965 that the Brazilian regime was an authoritarian one, that did not stop AIFLD Board Chairman and shipping magnate J. Peter Grace Jr. from commenting on the exemplary work the organization had done to rid Brazilian unions of communist infiltration or stop William Doherty from appearing onstage with coup leader Castello Branco and praising Brazil's “democratic revolution” (Black 1977, 119). As Jan Knippers Black (119) noted at the time, “...this 'democratic revolution' has meant frozen wages and a precipitous decline in real income, and to their leaders it has meant, among other things, that under provisions of 'Law 40' they are required to obtain certification of their 'good conduct,' of 'ideology,' and of 'democratic faith' from the police and from the Division of Political and Social Order (DOPS).”

Moreover, other AIFLD affiliated unions used the institute to further its own goals in line with the U.S. state in Brazil after the coup. Specifically, the International Federation of Petroleum and Chemical Workers (IFPCW) continually attempted to unify the Brazilian petrochemical workers after the coup without success. A Brazilian labor leader, Lourival Coutinho, believed this was part of a maneuver by AIFLD and the IFPCW in collusion with U.S. capital to gain access to Brazilian oil reserves and undermine the state-owned PETROBRAS. Moreover, another Brazilian union chief discovered a specific list of payoffs from IFPCW which included, among other things, a “special payment” for a Labor Ministry official, a trip for an "informer", funds to be used to defeat a specific labor candidate, and a bonus for a labor reporter "...for giving us 
favorable coverage" (Black 1977, 120-1). Even after the release of the information, AIFLD continued to operate in Brazil, opening labor centers and running training courses throughout the 1970s. Thus, in Brazil both the containment strategy and U.S. business interests played dominant roles in AIFLD activity rather than support for "democratic" trade unionism.

In South Africa, the AALC walked a fine line, often voicing displeasure at the apartheid system while at the same time undermining the African National Congress (ANC) and labor organizations that challenged the status quo. While the AALC's Irving Brown warned Congress that apartheid must be stopped in order to prevent a slide into totalitarianism (Communism), the AALC “...generally opposed South Africa's expulsion from the United Nations as well as international boycotts and campaigns for the withdrawal of foreign investment" (Agee 1979, 77). Thus, the AALC focused on developing labor organizations solely concerned with collective bargaining and excluded unions which linked themselves with broader societal change, including the Federation of South African Trade Unions (FOSATU) which had emerged as “...the only trade union organization which stressed the importance of marrying political and economic issues" (76).

The division between what the AFL-CIO and South African labor organizations wanted in regard to sanctions on businesses operating in South Africa remained a point of friction up until 1986. As In These Times reported in 1985 concerning a group of South African labor leaders visit to the U.S.: "[t]heir complaints underscored the AFL-CIO's internal divisions on South Africa, which parallel labor's better-known left-right split on Central America. Some American unionists want to end all U.S. economic links to South 
Africa. Others, including the AFL-CIO leadership, favor selective economic pressure but don't rule out "responsible" investing by some American firms" (Askin and Yuill 1985, 2). Although the AALC would change its tact in 1986, this came after the AFL-CIO awarded “...[i]ts George Meany Human Rights Award to apartheid collaborator Gatsha Buthelezi, who had created a labor center - United Workers of South Africa specifically to undercut the Federation of South African Trade Unions and the rest of the liberation movement” (Buhle 1999, 228; Scipes 2010, 36). AALC chief Irving Brown would be granted this same award after his death (Buhle 1999, 228). Brown himself directed his energies, among other things, to rehabilitating the image of "Chief" Buthelezi, appointed by the apartheid government to rule the Zulu "homeland" Kwazulu. Buthelezi notoriously opposed sanctions against the apartheid South African regime and the AALC spent significant time and energy supporting his union, the Council of Unions of South Africa which in turn directed its efforts at undermining Mandela's African National Congress, which the Federation (like the U.S. state) found too radical (227). Thus, the AALC's activities in South Africa closely mirrored the official U.S. state policy toward the apartheid regime for most of the Cold War. Specifically, AALC strategy began to shift alongside the official U.S. policy of "constructive engagement" initiated in the 1980s under President Reagan. Constructive engagement was based upon the ideas of Assistant Secretary of State for African Affairs Chester Crocker, who in a policy paper argued that under President Carter the U.S. had been too harsh in its rhetoric towards South Africa and that positive reinforcement would lead to the end of apartheid (Thomson 1995, 83-4). Under this strategy, labor was identified as a prime target for education and training, however only certain unions would qualify, and most certainly 
not the more radical FOSATU. As Thomson (97) writes: "[a]lthough the US Administration correctly identified the labour movement in South Africa as the black opposition's most progressive and effective lever of change, more aid was allocated to tertiary education projects, mainly because it was felt that the unions were not 'neutral' enough." In this regard, the Federation's foreign policy was linked into the wider U.S. policy of incremental change to prevent a radical opposition (who might not turn a blind eye to previous U.S. support of the apartheid system) from seizing power.

Similar stabilization campaigns were waged in Nicaragua, where AIFLD operated with the blessing of the Somoza regime from 1968 until shortly after his overthrow by the Sandinista's in 1979. In Nicaragua, AIFLD was closely allied with the Confederation of Trade Union Unity (CUS), which boasted a small membership of conservative unions that were "...formed in 1964 out of the merger of the pro-Somoza confederations, and had a total membership of 4,000 workers" (Rivera 1991, 245). Moreover, the “...CUS strongholds were U.S. multinationals and Somoza's businesses, which included ports, airlines, services and hotels" (Ibid.). In other words, AIFLD supported Somoza's pet unions and the organizations he allowed to function within Nicaragua.

However, after the Nicaraguan revolution, rather than join forces with the labor coordinating council which sought to align all trade unions under the Sandinista government, the CUS and AIFLD suddenly began advocating for a more robust "political" unionism, and united with the right-wing and business opposition to the FMLN until finally AIFLD was forced to leave Nicaragua altogether in 1982 after being accused of being a CIA front (Spalding 1988, 24). As Rivera (1991, 246) notes: "[t]he revolutionary government's suspicion of CUS' involvement in counter-revolutionary 
activities seems well-founded in light of the pattern of AIFLD assistance in Nicaragua. In 1965 and 1966, the CUS received $\$ 50,000$ and $\$ 60,000$ respectively. In spite of its reduced membership and small constituency it received some $\$ 148,626$ during $1977-78$, and a year later, its budget was increased to some $\$ 869,452 . "$ These funding patterns are of particular importance, as they mirror similar increases in areas of U.S. geostrategic importance throughout the Cold War. Nicaragua is also an intriguing case as the rhetoric coming from the AFL-CIO and AIFLD began to demand "democracy" for trade unions, even though they had supported the CUS under Somoza, hardly a beacon of democracy and human rights.

The Federation also worked to stabilize countries during the Cold War in places like Nigeria, where in the 1970s, the AALC's funding of its favored union, the United Labour Congress of Nigeria (ULCN), reached the point whereby “affiliates didn't bother to pay due to it" according to a Nigerian government investigation (Godfried 1987, 56). The AALC funded the ULCN as a non-communist alternative to the Nigerian Trade Union Congress (NTUC), but by 1976 the leader of the ULCN was pushed out of power after expressing reservations about the AALC and its ties to the CIA (Cohen 1979, 74). The Federation's drive to contain communism by allying with anti-left labor unions at all costs also extended to Kenya, where the AALC and Irving Brown worked through the Kenya Federation of Labor to support its leader, Tom Mboya, "with his signature Mercedes, designer clothes, and unshakeable pro-capitalist leanings" as he maneuvered for the presidency up until his assassination (Buhle 1999, 227).

Perhaps no regional activities by AIFLD drew as much attention from scholars and activists as its work in El Salvador (and Central America generally) during the 1980s. 
So much so that it created a broad debate within the AFL-CIO in regard to foreign policy and led to a coalition of labor leaders (including John Sweeney) who formed a group opposing AFL-CIO actions in El Salvador (and coincidentally gave many within the AFL-CIO hope that the Solidarity Center would take a new line on foreign policy under his presidency). In comparison with Nicaragua, where AIFLD worked with Somozalinked unions until forced to leave the country after the Sandinistas took power, in neighboring El Salvador the Institute had an uneven relationship with the various Salvadoran regimes during the $60 \mathrm{~s}$ and 70 s. Interestingly, during the early years of operation in El Salvador, AIFLD pushed a somewhat moderate position, which encouraged reform of the oligarchic Salvadoran economy through limited land reforms. The purpose of this moderate position was tied into U.S. policymakers' belief that limited land reform would lessen the threat of radicalization of Salvadoran workers. In fact, AIFLD in its earliest days in El Salvador supported popular causes: “...in the late sixties, it helped peasants buy land and organized community development projects. Thus, as early as 1968, AIFLD helped create the Salvadoran Communal Union (UCS) “... as a response to the growing progressive peasant movements in the countryside" (Deere 1982, 5). In fact, "it did this so well that in 1973 the military junta kicked it [AIFLD] out of the country" (Smyth 1987b, 2).

In 1979, a new military junta seized power and invited AIFLD back into the country, where it formed the Popular Democratic Unity (UPD) in 1980. During this time, AIFLD also used USAID funds to help implement modest land reforms that were widely considered a disaster. However, as Sims $(1992,76)$ notes: 
To carry out the program, AIFLD hired Roy Prosterman... Although unfamiliar with Latin America, Prosterman had other credentials which apparently appealed to AIFLD. He had worked in U.S.-sponsored agrarian counterinsurgency projects in Vietnam....and was familiar with using agrarian reform as part of a package of political instruments designed to win support for U.S. backed governments.

Further, the newly created and AIFLD backed UPD grew quickly “...in large part because it was one of the only labor coalitions allowed" (Smyth 1987b, 2). As security forces and repression destroyed rival unions and their leaders, the UPD became one of the largest union federations in El Salvador. During this period, AIFLD provided the majority of the funding for most of the organizations that comprised the UPD and worked to construct the "social pact" that allowed Jose Napoleon Duarte to win the presidency in 1984. The "social pact" brought moderate elements together under a series of pledges, and had the support of the UPD. When Duarte failed to deliver on campaign promises to prosecute human rights abuses and engage the FMLN in peace talks, and then instituted a series of IMF-led austerity measures in 1986, the UPD began joining with more radical labor organizations and formed the National Union of Salvadoran Workers (UNTS) (Smyth 1987, 316; Spalding 1992, 428). Faced with the Sandinista victory in neighboring Nicaragua and an escalating communist threat inside El Salvador, AIFLD again resorted to creating parallel unions to undermine the UPD.

The pushback by AIFLD and the U.S. state was extensive. Funding for projects and leaders were cut if UPD members did not pull out of UNTS (Sims 1992, 89). More disturbingly, as Frank Smyth (1987b) reported for Washington Monthly:

U.S. embassy and AIFLD officials were determined to prevent the opposition labor coalition from capitalizing on the unpopularity of the austerity measures. So they set up a pro-Duarte labor coalition--the 
National Union of Workers and Campesinos (UNOC) and parallel government-backed unions in the public and private sector. "Much of the credit for UNOC's creation goes to AIFLD," a March 1986 U.S. embassy memorandum states... Finally, it has been helpful to UNOC that the body that certifies new unions is the Salvadoran government. In some cases it has authorized pro-government unions, or eliminated anti-Duarte ones, without holding real elections. For example, management set up a union at the 1,000-employee Industrias Unidas, one of the largest textile plants in El Salvador. To influence the outcome of a union election to be held in March 1986, AIFLD's deputy director Donald Kessler promised the union an $\$ 8,000$ "loan." According to The Wall Street Journal, Kessler told the union point-blank: "If we're elected, you'll get the loan.' On March 16, though, union officials backed by AIFLD walked out of the election. The Ministry of Labor ordered a second election in May, at which point the AIFLD-backed leaders left the general meeting and held a separate vote among their own supporters. Four days later, without explanation, the Ministry of Labor recognized that union.

Disturbingly, in a 1993 "Final Report" on AIFLD and USAID collaboration in El Salvador, the conclusion was that "[o]n balance, AIFLD has achieved its objectives, and its strategies have been sound..." and that "AIFLD's strategy is to work through existing labor, cooperative, and informal sector organizations" (Stewart and Jimenez 1993, 6). The same report goes on to explain the creation of the UPD and UNOC as reactions to the formation and tactics of the FMLN while at the same time complaining that all involved pay "...considerable attention to political concerns at the expense of unionism" (18). El Salvador thus comprised a murky situation, but one where AIFLD worked together with the U.S. state in order to achieve a dual pronged strategy of economic austerity measures and containment of the FMLN.

In other Central American and Caribbean nations the efforts AIFLD engaged in similar stabilization campaigns under the banner of business unionism. For example, in Grenada AIFLD was called upon to “....restructure the Grenadian labor movement after 
the October 1983 invasion" (Spalding 1992, 425). One of their first acts of business was to gather sympathetic unions and to replace graffiti in support of the New Jewel movement with slogans welcoming the invading U.S. forces (Ibid.). Further, AIFLD stepped into post-invasion Grenada with a specific mission in-line with U.S. policy goals. As Boodhoo (1986,21-2) makes clear, AIFLD involvement in Grenada was aimed at “...reshaping the labor force thereby making it more amenable to the interests of the foreign investor especially with regard to conditions of employment and labor cost," and also "...directed toward preventing the re-appearance of a radicalized labor force." AIFLD involvement in stabilizing the post-invasion Grenada regime is especially troubling, as like the case of Haiti discussed below the AFL-CIO appears to be acting upon direction from the U.S. state to intervene.

In the 1980's AIFLD diverted its energies to Haiti in an effort to set up the Federation of Trade Union Workers (FOS). The FOS was specifically structured and designed to meet the criteria required by the Caribbean Basin Initiative (CBI), which stipulated that member states could export certain goods to the United States with lower tariffs as long as specific criteria (such as the right to organize) were in place. Moreover, the CBI was being pushed by business interests that wanted the creation of "free zones" where U.S. corporations could set up assembly plants and benefit from much cheaper labor just off the U.S. coast. Critically, like in Grenada, AIFLD involvement came at the behest of the U.S. government "because of the presence of radical labor unions and the high risk that other unions may become radicalized" (Spalding Jr. 1988, 14). The CBI conundrum in Haiti was underlined by the fact that Jean-Claude Duvalier refused to recognize, and indeed cracked-down upon, the larger anti-Duvalier unions such as the 
Autonomous Central of Haitian Workers (CATH) and the CATH-CLAT (an offshoot of the CATH which aligned with the Confederation of Latin American Workers) (Sims 1992, 26-7). To further complicate matters, the CATH and CATH-CLAT were unaligned with either the U.S. or U.S.S.R. in the Cold War and thus, to the U.S., were unacceptable labor partners in Haiti. Therefore, AIFLD was tasked with finding or creating a labor movement that would be amenable to both Duvalier and the U.S. state. The solution was the creation of the FOS as the sole recognized representative of Haitian labor under the Duvalier regime and therefore part of the foundation of the CBI (Sims 1992). There was initial optimism that the labor component of the CBI addressed "...a concern that the labor laws and conditions in some countries would prevent the benefits of the Caribbean Basin Initiative from reaching the workers" (Charnovitz 1984, 54). However, in the end it is less than clear that the creation and maintenance of a parallel union structure in Haiti did anything more than disable the political voice of previously organized workers. Rather, the creation of the FOS merely gave legal backing to the implementation of the CBI, and undermined unions opposed to the Duvalier regime like the CATH and other popular organizations. Therefore, again we see AIFLD, under the guise of promoting democratic unionism, merely bolstering authoritarian regimes aligned with the United States based on economic interests and the containment strategy.

In Asia, more stabilization strategies were pursued by the AAFLI, most troubling in Korea and the Philippines. In the Philippines, Ferdinand Marcos created the Trade Union Congress of the Philippines (TUCP) as the official labor organization of the government. The TUCP fit into the "bread and butter" style unionism that the AFL-CIO supported both at home and abroad, as it "...called for the deregulation of business and 
denounced demands for the repatriation of corporate profits to Filipinos" (Buhle 1999, 228). Therefore, following the by now somewhat repetitive pattern, the AAFLI supported the TUCP to the hilt as it battled the Kilusang Mayo Uno (KMU) for the hearts and minds of Filipino workers. According to an International Labor Reports study, from 1983-1989 this battle was not cheap, as “ “...the AFL-CIO provided more money to the Marcos-created Trade Union Congress of the Philippines (TUCP) to use against the progressive Kilusang Mayo Uno (KMU) Labor Center than it gave to any other labor movement in the world, including Poland's Solidarnose" (Scipes 2010, 36). The TUCP adhered to the tripartite cooperation model, in essence becoming a partner with business and the state, however its independence was a paper tiger, as "[c]ritics charge that labor is an unequal partner in the arrangement and that the T.U.C.P. has been co-opted by the government. The federation rarely challenges antilabor laws and has even defended mass arrests of workers" (Shorrock and Selvaggio 1986, 170).

Defending their actions, AAFLI officials adamantly described the KMU as "communists" and insisted that funding for the TUCP through the AAFLI were of high strategic value, arguing “[i]magine if you have $\$ 100,000$ to give out to families in $\$ 500$ chunks. Your stock goes way up, faster than the stock of any of the militant labor groups" (171). Though block allocations information was released, the exact details of the way funds are allocated in country are often kept secret. The reasoning for such secrecy was revealed in a 1985 internal memorandum from the AFL-CIO to the National Endowment for Democracy (NED), which listed “...the Philippines among the countries that might be 'endangered or embarrassed' if specific budgets were announced" (Ibid.). The AAFLI alignment and support with the TUCP remains one of the most controversial activities of 
the AFL-CIO abroad. Of particular concern was the battle over Atlas Mines where the TUCP attempted to undermine the KMU and “...with no exaggeration this included active collaboration with a death squad" (Scipes 2010, 36).

The AAFLI also supported the military government of South Korea and the government-sanctioned Federation of Korean Trade Unions (FKTU) during the 1970s and $80 \mathrm{~s}$. The FKTU was thoroughly incorporated into the state apparatus, and therefore at least on its face value should have been another example of non-independent trade unionism of which the AAFLI was allegedly opposed (Ibid.). However, this was not the case as during the crackdown on labor in the early 1980s the AAFLI doubled down on its alleged apoliticism: "I think the movement here should just stick to the straight and narrow economic issues... as we've seen in El Salvador, it's possible for independent unions to develop in an authoritarian setting" claimed one AAFLI official (Shorrock and Selvaggio 1986, 172). Moreover, what ends were actually being served in both the Philippines and South Korea remains the key question. As Shorrock and Selvaggio argue:

The overriding issue is whether AAFLI serves the interests of workers and trade unionists. In both the Philippines and South Korea there is strong evidence that under the cover, of building free trade unions, the institute supports only those unions and labor organizations that do not challenge the status quo. In this way it serves the interests of U.S. foreign policy-and its guiding lights, the multinational corporations. Since 1980, U.S. corporations have directly invested more than \$200 million in the Korean automobile, electronics and computer industries. With billions of dollars in loans from U.S. banks, these ventures are rapidly expanding their exports to the United States. In the Philippines, labor movement that AAFLI is fighting opposes not only the presence of U.S. military bases but also the dominance of U.S.-based multinationals, which have long exploited the country's cheap labor and rich natural resources. The number of U.S. jobs that have been lost as a result of labor repression in these countries is impossible to quantify, but it is surely substantial. By 
limiting its aid to unions friendly to American interests and maintaining a silence about the serious deterioration of labor rights in these countries, AAFLI is contributing to the repression and helping to speed the process of capital flight from the United States to the Third World (1986, 172-3).

In addition to undermining labor movements in Asia, the AAFLI also supported very specific U.S. geostrategic goals in the South Pacific, fighting the anti-nuclear movement in Fiji with a million dollars' worth of support to the Fiji Trade Unions Congress (FTUC) (Buhle 1999, 228). As Sims $(1992,86)$ notes, the AAFLI's support of the FTUC included various aid, but most critically: "[i]ts major efforts occurred in 1984, however, when the U.S. institute opened an office in Fiji as part of a campaign to defeat the nuclear-free Pacific resolution advanced by the Pacific Trade Union Forum.” Even more to the point, Sims cites a funding request by the AAFLI to the National Endowment for Democracy in 1986, where the Institute argued that:

The trade unions of the island nations of the South Pacific are fragile institutions...their ability to see distinctions between the Soviet bloc and the democratic nations of the world is sometimes clouded, especially when emotional issues such as colonialism, nuclear testing, and economic protection zones are introduced into the discussion... With the exception of political parties, these trade union organizations are the largest mass organs in their countries (86).

Finally, in the former Soviet Union the AFL-CIO worked to stabilize post-Soviet Russia by outmaneuvering labor organizations that fought against privatizations and "shock therapy" and funding campaigns for politicians that supported these policies. In 1990, members of the former Soviet labor organizations met and dissolved the old Soviet controlled union and replaced it with the General Confederation of Trade Unions (FNFR), which would represent an astounding 50 to 60 million workers. The FNFR was 
extremely active, not only publishing a paper and creating a labor college, but most importantly trying to preserve much of the benefits and protections afforded to laborers under the Soviet system (Buhle 1999, 242).

However, as the Russian economy was pried open by foreign investors, the AFLCIO showed no interest in working with the FNFR and immediately moved to undermine the organization through its now familiar tactics of establishing parallel unions and granting material benefits for defectors. As Paul Buhle notes: "Funded heavily by the NED and other U.S. agencies and paying salaries huge by Russian standards, the socalled Free Trade Union Institute's client organizations set out to 'organize' unionists who already belonged to other labor organizations" (242). The FNFR continued to be one of the only barriers to rapidly diminishing wages, life expectancies, and standard of living as Russia was sold off piecemeal to private investors who would later form the backbone of Russia's post-Soviet oligarchy. Moreover, the FNFR enraged the Federation by supporting socialist politicians and fighting against Yeltsin's auto-coup in 1993, all of which served to further distance the organization from the FTUI and Russian elites. By 1996 the FTUI was “...pouring money into Yeltsin’s 1996 re-election campaign, financed by assorted U.S. sources with tens of millions of dollars, against election rules" and also working with the American Federation of Teachers (AFT) to replace“...old Russian curricula with a 'democracy curriculum' idealizing U.S. global leadership and the American way of life" (243).

Thus, as the above-mentioned cases make clear, when dealing with client regimes of the U.S. state, or in regions where the U.S. state believed communists were lurking, the foreign policy of the AFL-CIO involved supporting dictatorial and authoritarian 
regimes through outmaneuvering popular movements as well as progressive and leftist organizations. For a forty year span, in places such as the Philippines, South Korea, El Salvador, Brazil (after the 1964 coup), and a host of other locations, the Federation clearly worked with labor organizations controlled by authoritarian regimes, rather than pursuing their stated goals of developing "free" trade unions. In some cases AFL-CIO foreign policy dovetailed with U.S. state goals, while in others (Haiti, Grenada, and Europe under the FTUC) the Federation operated at the behest of U.S. policymakers. The track record is fairly clear: the Federation's foreign policy in all of the cases described above had little to do with "free" trade unionism and everything to do with containing Soviet influence and expanding the power of U.S. capital.

To meet these ends, the Federation used a variety of tactics to achieve stabilization of client regimes, including: creating parallel unions to counter labor organizations opposed to the role of the United States, channeling funds to favored candidates, and even strong-arming unions into supporting U.S. geostrategic goals with a carrot or stick strategy. As will be discussed later, the vast majority of the funding for these operations came directly from the U.S. state via intelligence organizations (the CIA) or through government-funded "quasi" governmental groups like USAID and the NED. However, before turning to the question of funding, we first turn to the foreign policy of the AFL-CIO for regimes that were deemed "enemies" of the U.S. state. A set of policies that looked much different from the apoliticism preached inside client regimes of American policymakers. 


\section{The AFL and AFL-CIO \& the Cold War: Destabilization}

The foreign policy of the Federation during the Cold War is partially illuminated by the stabilization strategies employed in places like South Korea, the Philippines, El Salvador, and Haiti. Yet, this is only part of the story. Though less numerous, the AFL$\mathrm{CIO}$ has been linked to several de-stabilization campaigns in areas of geo-strategic importance to the United States. In the cases discussed below, the foreign policy arms of the Federation actively engaged in activities designed to overthrow (or contribute to the removal of) regimes that were enemies of the U.S. state. Under the containment policy articulated in NSC 68 that formed the backbone of American foreign policy during the Cold War, this meant regimes aligned with Moscow as well as regimes that refused to align with American business interests.

In 1954, shortly before the merger of the AFL and CIO, the Federation and ORIT was accused of helping overthrow the democratically elected government of Jacobo Arbenz in Guatemala, whom George Meany and the American state considered a communist. Arbenz's opponents in the previous election consisted of candidates supported by a small coterie of agricultural elites and importantly, the United Fruit Company (for an excellent overview see Bitter Fruit). Although Arbenz was not a communist, his refusal to ostracize and alienate supporters who were affiliated with the left quickly drew the ire of U.S. policymakers. After a series of land reforms that infuriated the United Fruit Company and the United States, Meany sent Arbenz a letter that, among other things demanded he purge his staff as well as Guatemalan unions of communists and warned that his actions were tantamount to entering the Soviet sphere. At the same time, the CIA and the Federation's point man in Guatemala, Serafino 
Romualdi (who incidentally had been kicked out of the Guatemala by Arbenz for agitation) were plotting a coup to bring Colonel Castillo Armas to power. Shortly thereafter, the military coup went off without a hitch and Arbenz was sent into exile while Armas turned Guatemala into a right-wing dictatorship and created what is widely considered Latin America's first death squad (Buhle 1999, 143-4; Morris 1967, 80-1). Thus, the activities of the Federation in collusion with the U.S. state indicate that when faced with a regime deemed hostile to U.S. interests, economic, political, or both, the Federation was willing to use its power to destabilize and remove democratically elected governments in the developing world.

However, Guatemala was but one example of the de-stabilization campaigns of the Federation in collusion with American foreign policy. In 1963, AIFLD spent "well over a million dollars to provide strikers better than normal daily pay" to drive democratically elected President Cheddi Jagan out of power in British Guiana (Buhle 1999, 152). Jagan was actually driven from power first in 1953 by the British, who also believed him to be under Soviet influence. The United States was pleased with this action by the British, and went as far as to fund an interim government afterwards. However, in 1961 Jagan was re-elected and the CIA and AIFLD began a series of maneuvers designed to cripple the government, by funding strikers and organizing and supporting non-left unions within the country (Waters Jr. and Daniels 2006). Thus, AIFLD proposed to reward unions that were opposed to Jagan by building over 2,000 low-cost housing units for their members and also “...brought six Guyanese unionists to Washington for the AIFLD's first class on leadership training" (Rabe 2005, 101). These graduates of AIFLD's training program returned to British Guiana in 1963 and helped 
lead the violent strike against the Jagan government while still on the AIFLD payroll (101).

To be fair, the politics involved in the British Guiana case are far less simple than presented here. As Waters Jr. and Daniels (2006) point out in their work on AIFLD, the CIA, and British Guiana, there were significant racial and sectoral policies at play. However, even with their nuanced account of the realities of the situation the authors admit that "[o]n the charge that the AFL-CIO was closely tied to the CIA in its Guianese work, the verdict is, guilty, just as US trade unions were guilty of having worked with US intelligence to stop communists from taking over the Italian and French trade union movements at the onset of the Cold War..." (1096). Analyzing the larger context it is clear that AIFLD was being funded by the CIA and acting as an arms-length agent of the U.S. state in British Guiana. To be clear, one thing that is conspicuously absent from the episode is an accounting from either the Federation or AIFLD that would explain why British Guiana was an important strategic location for labor operations in the first place. The then-British colony arguably preoccupied U.S. policy-makers through Cold War lenses, but its tactical value in terms of the foreign policy of U.S. labor was minimal. This fact was bolstered with an awkward incident in 1994, when President Clinton nominated Bill Doherty Jr. as an ambassador to the now independent Guyana. Awkwardly, Doherty Jr. was formerly a high ranking official for AIFLD when Jagan was removed from power, but by '94 Jagan had been returned to power through the ballot box again. President Jagan refused Doherty’s ambassadorship stating that “[m]aybe President Clinton doesn't know our history, but the people who advise him should at least know 
their own history" in reference to Doherty Jr. not mentioning his role in Guyana some 30 years earlier (Waters Jr. and Daniels 2006, 1078).

At the same time that AIFLD was helping overthrow the government of British Guiana the institute also played a major role the Brazilian coup that toppled the government of President Joao Goulart in 1964. Goulart enjoyed support from the largest Brazilian union organization, the General Workers Command (CGT), a left-dominated, progressive labor movement which AFL-CIO and U.S. state elites decried as communist. Besides refusing to take sides in the Cold War, Goulart also came into office facing economic troubles. Brazil faced an acute balance of payments crisis in the late 1950s and early 1960s and President Goulart was faced with both the IMF and foreign investors pushing for increased austerity measures. Goulart's refusal to accede to these demands, and his implementation of a Profit Remittance Law, as well as land expropriations and nationalization of oil refineries finally culminated in a military coup in 1964 (Gribbin 1979).

As Gribbin notes, AFL-CIO leaders were critical of the CGT even before the Goulart presidency. As early as 1956 “AIFLD's goal was the development of a core of labor leaders who, by commanding the enthusiastic support of the rank and file could turn back Communist attempts to capture the Brazilian labor movement" (Romauldi 1967) (as cited in Gribbin 1979, 16). Initially, the crux of support went to undermining the power of the CGT to unify the Brazilian labor movement under one banner (Gribbin 1979, 17). However, AIFLD also engaged in training programs whereby union members would be "educated" either by AILFD in their home countries or in the United States. In fact, immediately before the overthrow of regimes in Brazil and Chile "AIFLD training 
programs rose by $400 \%$ and $600 \%$ respectively" (Spalding Jr. 1988, 20). Specifically, in 1963, AIFLD invited 33 Brazilian unionists for special training in Washington including courses on “...U.S. labor history, economics, structures, and techniques for identifying and defending themselves and their unions against communists and fascists" (Welch 1995, 77). Upon completion of their training, these union members returned to Brazil and helped overthrow the Goulart regime (Black 1977, 117; Welch 1995, 77). Although scholars disagree on the exact role trainees played, AIFLD's Executive Director, William C. Doherty Jr., was explicit in a 1964 radio interview that the trainees had played a role in the military coup:

...when they returned to their respective countries, they were very active in organizing workers, and helping unions introduce systems of collective bargaining, and modern concepts of labor-management relations. As a matter of fact, some of them were so active that they became intimately involved in some of the clandestine operations of the revolution before it took place on April 1. What happened in Brazil...did not just happen--it was planned--and planned months in advance. Many of the trade union leaders - some of whom were actually trained in our institute - were involved in the revolution, and in the overthrow of the Goulart regime (Black 1977, 117).

A Brazilian communications unionist was more specific, claiming that upon return the trainees held seminars on how to stop communist infiltration of unions and what steps needed to be taken to stop it. More directly, this trainee “... warned key workers of coming trouble and urged them to keep communications going no matter what happened. When the call went out for a general strike to frustrate the coup attempt, the communications workers failed to respond" and thus made sure military units were able to communicate during the coup (Ibid.). 
As a final note, much like the case of British Guiana, even scholars who are less critical of the role AIFLD played in the destabilization and overthrow of these regimes (or at least point out the gray areas of AIFLD policy) admit that the organization was little more than a willing accomplice of U.S. state goals. "The idea of overthrowing President Goulart did not originate with U.S. labor policymakers, but their impatience with the training program and their frustration with his administration led them to spend little time pondering the ethics and morality of participating in the overthrow of a legitimate government" (Welch 1995, 77).

In addition to destabilization programs in British Guiana, Brazil, and Guatemala, AIFLD was also involved in the successful series of strikes coordinated and financed by the U.S. state in Chile which resulted in the removal of Salvador Allende in 1973. After Richard Nixon asked the CIA to "make the (Chilean) economy scream" in response to the election of the socialist Allende in 1970, the United States funneled millions of dollars into funds to support striking truckers and businesses in order to shut down the Chilean economy and create economic chaos (see Hirsch and Muir 1987; Scipes 2010). Probably as a consequence of the exposure of its earlier activities in Guatemala and Brazil, AIFLD denied all involvement after the coup. However, the record indicates that AIFLD was involved in organizing rival unions to the General Confederation of Workers (CUT), which with over two million members in 1973 was easily the largest union federation in Chile (Hirsch and Muir 1987, 752). Specifically, the policies of the Allende government targeted wage increases for "lower paid workers" and thus alienated middle class and professionals who were ripe for the type of parallel unions that AIFLD created and supported (Ibid.). 
Moreover, as mentioned above, AIFLD also greatly increased the amount of "training" programs in Chile immediately following the election of Allende. Although it is unclear exactly where these workers came from or went, it is clear that the CUT was hostile to AIFLD and adamantly behind Allende and therefore, as Scipes points out, it would be very unlikely that these trainees would have been drawn from the ranks of the CUT. A much more likely scenario, and one that has significant weight from the details and documents that have emerged, is that the truck drivers unions (which were controlled by owners of the trucking industry), maritime unions (made up of mostly officers), and white-collar unions such as the Confederation of Chilean Professionals (CUPROCH) were courted and supported by AIFLD (Scipes 2010, 45). These sorts of professional and middle class union organizations were much more acceptable and amenable to the type of business unionism and anti-communism espoused by AIFLD. Furthermore, Allende fingered CUPROCH in his final address as being behind the destabilization of his regime, and this link was later bolstered by William Doherty Jr., who claimed the same in a 1974 speech (Hirsch and Muir 1987, 745; Scipes 2010, 46). As with the British Guiana, Guatemala, and Brazil, AIFLD was a willing and active partner in the process of destabilization in Chile in 1973, a goal shared by American policymakers and business elites.

Finally, although more research is needed, AALC operatives including Irving Brown have been accused of organizing the National Front for the Liberation of Angola (FNLA) by supplying its leadership with cash through a labor organization front (Sims 1992, 58). Moreover, this linkage with the FNLA led to a close relationship between Brown and Jonas Savimbi, who Brown would describe “... as a great fighter for freedom 
whose concept of democracy comes as close as anyone in Africa to our image of what is a free and democratic society" (Buhle 1999, 226).

In summation, during the Cold War, the four regional institutes were intimately involved in several high-profile de-stabilization campaigns that led to the overthrow of democratically elected governments in the developing world. Along the way, the Federation often created, funded, and maintained parallel union structures where significant labor organizations already existed. While labor organizations of client regimes of the U.S. state received business unionism and "free" trade union funding, unions in other regimes, which failed to fall in line with U.S. geostrategic goals, were targeted for regime change.

These two categories of case studies are critical, as in the following chapters the work of the AFL-CIO's Solidarity Center will be examined using similar criteria. The main proposition remains: is AFL-CIO foreign policy still best explained by the exigencies of the U.S state? Before moving into an examination of the Solidarity Center, however, it is critical to examine a strategic shift in U.S. foreign policy that occurred in the early 1980s. Specifically, beginning with the election of Ronald Reagan to the presidency in 1980, the Cold War emphasis on "anti-communism" and containment gave way to that of "democracy promotion." Moreover, this shift was related to an evolution of funding patterns over time: while labor worked with direct CIA and U.S. state funds in its earliest years, USAID would become its principal benefactor for much of the Cold War before eventually giving way to the modern constellation of funding flows that find the NED at the forefront of Solidarity Center resources. In order to understand this evolution and to properly analyze the Solidarity Center's relationship with the U.S. state 
today, we now turn to the theoretical importance of democracy promotion, polyarchy, and its roots.

\section{Shifting Funding Flows: Labor, the NED, and "Democracy Promotion"}

As developed in the preceding sections, the foreign policy of the AFL-CIO

showed a strong correlation with U.S. foreign policy goals during the Cold War. The emphasis on anti-communism and support for American business interests as well as the linkages between the CIA, State Department, and AIFLD, AALC, FTUI, and the AAFLI has been well documented by a variety of scholars and labor activists. However, placing these case studies into stabilizing and destabilizing categories as done above, helps illuminate the fact that the Federation's foreign policy from World War II until the end of the Cold War was based more on the predilections of the U.S. state than on any firm commitment to labor internationalism or "free" trade unions. During this period, the AFL-CIO occasionally worked to destabilize democratically elected governments in the name of containment and anti-communism, while at other times stabilizing authoritarian regimes at the behest of the U.S. state in the name of "pure and simple" trade unionism.

Scholars have attributed a variety of reasons for the policies of the AFL-CIO abroad, including the predilections of its leadership and the impetus of the struggle with the Soviet Union for the hearts and minds of the working class overseas. Both explanations are at least partially convincing at different times and in various locales. At times the AFL-CIO acted as a mere conduit for CIA funds and aims, while at others it appears that the federation leadership played a more integral role in determining policy. The present work argues that the most relevant point for understanding the role of 
American labors' foreign policy begins with analyzing the connections between U.S. state policy and the Federation. The most direct way to analyze this connection is thus to examine the funding flows that enabled the institutes to bolster U.S. foreign policy during the Cold War. Again, while some scholars make the case that labor's foreign policy is internally constructed, an examination of the cash flows between the American government and its agencies and the AFL-CIO indicates that is likely not the case. In its simplest terms, up until the formation of the Solidarity Center there have been two eras of AFL-CIO funding and related strategy. Prior to 1984, the regional institutes received the bulk of their funding from the U.S. state via the United States Agency for International Development (USAID), however as will be evidenced in Chapter 3, the specifics of funding for the institutes is less than crystal clear. Some figures are available, for example a GAO report from 1996 broke down funding to AIFLD from 1980-1994 and indicated quite clearly that at least for Latin America and the Caribbean, nearly $99 \%$ of funding came from USAID (see figure 2.1 ). Especially prior to the creation of the National Endowment for Democracy (NED) in 1984, USAID contributed nearly all the funding for the institute while the AFL-CIO used only a very small percentage of its own funds for AIFLD operations. The column marked "private funds" includes both AFL-CIO and private (unidentified) assistance, while the "other" column refers to sources of U.S. government funds not from USAID, the NED, or the United States Information Agency. According to the GAO: "[f]or fiscal years 1980 through 1994, AIFLD received about $\$ 215$ million, of which USAID provided about 87 percent, the National Endowment for Democracy (NED) provided about 10 percent, the private sector provided about 2 percent and the U.S. Information Agency provided the 
Table 2.1 American Institute of Free Labor Development Funding 19801994, in millions of dollars

\begin{tabular}{ccccccc} 
Year & USAID & USIA/NED & Other & $\begin{array}{c}\text { U.S. } \\
\text { Funds }\end{array}$ & $\begin{array}{c}\text { Private } \\
\text { Funds }\end{array}$ & Total \\
\hline 1980 & 9.44 & 0 & 0 & 9.44 & 0.41 & 9.85 \\
1981 & 10.65 & 0 & 0 & 10.65 & 0.43 & 11.08 \\
1982 & 9.84 & 0 & 0 & 9.84 & 0.36 & 10.2 \\
1983 & 11.01 & 0 & 0.11 & 11.12 & 0.27 & 11.39 \\
1984 & 12.9 & 0.81 & 0.26 & 13.97 & 0.3 & 14.27 \\
1985 & 12.34 & 4.37 & 0.12 & 16.83 & 0.21 & 17.04 \\
1986 & 12.44 & 0.13 & 0.13 & 16.65 & 0.34 & 16.99 \\
1987 & 13.15 & 0.13 & 0.13 & 15.36 & 0.38 & 15.74 \\
1988 & 13.66 & 0.1 & 0.1 & 15.15 & 0.44 & 15.59 \\
1989 & 14.41 & 1.89 & 0.15 & 16.45 & 0.33 & 16.78 \\
1990 & 14.35 & 1.68 & 0.18 & 16.21 & 0.29 & 16.5 \\
1991 & 14.94 & 1.39 & 0.15 & 16.48 & 0.31 & 16.79 \\
1992 & 14.25 & 1 & 0.03 & 15.28 & 0.26 & 15.54 \\
1993 & 13.78 & 1.12 & 0 & 14.9 & 0.26 & 15.16 \\
1994 & 10.58 & 1.24 & 0.03 & 11.85 & 0.29 & 12.14 \\
\hline Total & 187.74 & 21.05 & 1.39 & 210.18 & 4.88 & 215.06 \\
\hline
\end{tabular}

Source: GAO Report 1996

remainder" (U.S. General Accounting Office [GAO] 1996, 1). In other words, some 98\% of AIFLD funds were directly from government sources during this period. According to the same report:

During the 1980s, AIFLD operated throughout Latin America, primarily with USAID funds. In fiscal years 1993 and 1994, AIFLD operated in 20 countries using USAID and NED funds. In 19 of these countries, AIFLD projects were funded by USAID's centrally administered regional grant and/or through grants that were managed in-country by USAID missions. AIFLD used NED funds for a project directed toward Cuba. AIFLD also 
used NED funds in 10 other countries where it was spending USAID funds (GAO 1996, 6).

The listing of countries is exhaustive and includes Argentina, Bolivia, Brazil, Chile, Colombia, Costa Rica, Cuba, the Dominican Republic, Ecuador, El Salvador, Guatemala, Haiti, Honduras, Mexico, Nicaragua, Panama, Paraguay, Peru, Uruguay, Venezuela, and regional grants (GAO 1996, 7).

Although the activities of the four regional institutes have been well documented in the previous sections, this work is concerned with identifying patterns of behavior by the Solidarity Center post-1997. As will be explored more fully in the following chapter, there has been a dramatic shift away from direct CIA and (more recently) USAID funding in favor of NED grants. Beginning slowly in 1984, after the creation of the NED, this source of grants has evolved to the point whereby in 2009, NED grants accounted for approximately half of all Solidarity Center funding.

Most importantly, the key point to consider here is that the NED is not just a new source of funding, but involves a new type of foreign policy apparatus that has shaped to a significant degree the way the AFL-CIO envisions its mission abroad. The NED's goal of "democracy promotion" actually entails a very specific understanding of democracy that has altered not just U.S. foreign policy, but AFL-CIO foreign policy as well.

\section{The Creation of the National Endowment for Democracy}

The National Endowment for Democracy was created in 1983 and began operations in 1984, and like many of the USAID projects, was conceived of as a tripartite organization, with business, labor, and both U.S. political parties at the center of its 
operations. The AFL-CIO has held a special position in the organization as the founding members included AFL-CIO President Lane Kirkland, as well as Congressman Dante Fascell (D), U.S. Trade Representative William Brock, and George Agree (Carothers 1994, 125). The basic idea behind the creation of the NED was simple: to provide a conduit for government funds that would be privately managed. Thus, the NED operates as “.... p privately incorporated nonprofit organization with a Board of Directors comprised of leading citizens from the mainstream of American political and civic life..." which targets the promotion of "democracy" as its primary function (NED 1998). Interestingly, the NED (1998) was defined by the principle that "politics" should not stand in the way of promoting democracy abroad:

The expansion of private, voluntary initiatives to promote democracy internationally cannot be accomplished through governmental action alone. Indeed, the creation and structure of the Endowment reflect the view that the U.S. private sector is both a more appropriate and a more effective vehicle than government for working with private groups abroad to advance the democratic cause. The flexibility afforded by the Endowment's nongovernmental character gives it a crucial advantage in developing relationships of partnership and cooperation with foreign organizations... By its very nature such support cannot be governed by the short-term policy preferences of a particular U.S. administration or by the partisan political interests of any party or group.

The "arms-length" relationship with the U.S. state was the crucial link for the founders of the NED, however it was especially important for the AFL-CIO, as Thomas Carothers (1994, 125) makes clear:

They believed that democracy promotion was a necessary means of fighting communism and that, given sensitivities about U.S. government intervention abroad, such work could best be done by an organization that was not part of the government. The AFL-CIO had a particular interest in such an organization as a potential source of funding for its international union-building activities to replace the covert funding that the AFL-CIO 
had received in the 1950s and 1960s but had largely stopped receiving in the 1970s.

Then AFL-CIO President Lane Kirkland claimed that the federation had the most experience of international activity for promoting democracy through its labor institutes while founding member William Brock, a Republican Senator who would later be named Secretary of Labor by Reagan, said that the AFL-CIO's track record mean the federation “...has been one of the most effective tools the U.S. has possessed in the postwar period to halt the spread of communism through subversion of workers' movements in the developing world" (Sims 1992, 42).

The NED is comprised of four "core" grantees and numerous other smaller organizations who apply for grants using U.S. state funds to carry out a wide range of activities abroad. These four core grantees form the tripartite nature of the NED. Represented are domestic political interests through the National Democratic Institute for International Affairs (NDI) and International Republican Institute (IRI), as well as business interests through the Center for International Private Enterprise (CIPE). The Solidarity Center is now the "representative" of labor, although prior to 1997 this function was fulfilled by the FTUI. In practice the NED performs a simple function: it distributes federal funds through "private" organizations and "...allows the NED to present itself as stemming from American civil society rather than an organization situated in the field of state power" (Guilhot 2005, 85). Thus, the NED is almost always referred to as a "quasi-governmental" or a "non-governmental" entity which is somewhat absurd, as it seems "...to be based on the premise that government money, if filtered through enough layers of bureaucracy, becomes 'private' funding" (Ibid.). 
Thus, the NED was the culmination of an evolutionary arc in U.S. foreign policy. As early as 1967, Congressman Fascell attempted to create an "Institute for International Affairs" that would perform much the same function as the NED today. With the election of Ronald Reagan in 1980, a similar organization was proposed, however with a focus on "human rights" (Guilhot 2005, 84-5). However, the neo-conservative vision promoted by Reagan and his allies was not a vision of international human rights in the manner promoted by organizations like the U.N., but rather derived from national structures of power. Under this conception "...human rights were primarily based upon a set of values embedded in existing national political institutions and legal structures, of which the United States were at once the best historical example and model" (75). In theory, this definition of human rights can be conceived of as negative government power exemplified by free markets, free labor, and American style democracy as opposed to a more holistic vision which places specific duties on the state to provide social safety nets and the like. Therefore, “...the neoconservatives produced a theory of human rights that excluded social and economic entitlements and ensured the continued political and economic dominance of the center over the periphery, against any challenge to the capitalist world-system" (77). This was the evolution of the type of "assistance" the U.S. state gave to the developing world in the " 50 s and " 60 s via organized labor through the CIA and USAID which transformed and intertwined U.S. state interests and anticommunism with democracy promotion and development. As "covert" operations of the U.S. state came under increasing scrutiny from Congress and the media, this form of “overt" influence had significant appeal to policymakers (Robinson 1996, 92). 
Therefore, the NED can be seen as a "policy legitimizer". That is, the NED became a vehicle to legitimize relationships that were already established through a network of NGO's (like the four foreign labor institutes or the Solidarity Center today). Operating as a "private" organization the NED can fund partners in other countries without congressional oversight and with a veneer of legitimacy as "private" actors. Whereas funding might be previously funneled discreetly to political actors that were sympathetic to U.S. goals, they could now be channeled through the NED to those same actors via democracy promoting activities.

\section{The NED and Democracy Promotion as "Limited Democracy" or Polyarchy}

If the creation of the NED led to a new form of intervention abroad, apart from the CIA orchestrated overthrow of democratic governments and the support for authoritarian regimes during the Cold War, then what type of outcome is associated with this new era of democracy promotion? Perhaps the best theoretical explanation for this policy lies within the sphere of what scholar term "limited democracy" or William I. Robinson, borrowing from Robert Dahl, terms "polyarchy." As William Aviles contends, the shift to democracy promotion was the outcome of several phenomena. First, U.S. support for authoritarian regimes was coming under increasing fire domestically. As the Cold War was winding down it was less politically prudent to support dictators under the mantra of anticommunism, especially if those authoritarians were engaged in widespread and documented human rights abuses. Second, this process was evolutionary, in that policy elites debated and constructed several different models of U.S. foreign policy that attempted to weigh the pros and cons of authoritarian support. 
Finally, and perhaps most critically, global capitalism had spread to a point whereby a significant majority of what William Robinson terms the "transnational capitalist class" were amenable to U.S. strategic goals and shared a common vision with U.S. policymakers. In short, there was little need to coerce and more of a need to bolster and encourage foreign elites to buy into the current global configuration of power (Aviles 2012; Robinson 1996, 622). A further point is made by Avri Beard, who argues that the transition from authoritarian rule was not only pushed by the U.S. state and policymakers, but accepted by foreign elites who ran a personal calculus to determine that democracy, especially the type being promoted, was more cost-effective than authoritarianism (Beard 2004, 2). Moreover, the fact that foreign elites were willing to engage in elections was premised around the idea that "[e]lite commitment to democracy, however, is restricted to controlled or limited elections and to governments that do not threaten their fundamental economic interests...the results of these new processes discourage meaningful mass participation" (Ibid.). Beard's analysis is a valuable addition to the literature which shows how elites viewed their interests in the transition to democracy, but it also is an extension of the most powerful scholarship on the subject: William I. Robinson's Promoting Polyarchy. Robinson (2004, 81-2) argues that the democracy promotion program of the NED and the foreign institutes of the AFL-CIO involves a specific type of democracy that is intimately tied into U.S. geostrategic aims:

Polyarchy refers to a system in which a small group actually rules, and participation in decision making by the majority is confined to choosing among competing elites in tightly controlled electoral processes. This "low-intensity" democracy does not involve power (cratos) of the people (demos), much less an end to class domination or to substantive inequality, which is growing exponentially under globalization. 
Under conditions of polyarchy, the economic rules of the game are guaranteed, while the democratic aspect is configured for a very narrow political competition for leadership positions between parties. In short, as scholar and activist Kim Scipes argues “...do they get to vote for Pepsi or do they get to vote for Coke" (Scipes and Hirsch 2005).

Crucially for this study, efforts at democracy promotion and polyarchy cultivation tend to be focused on areas of strategic importance. As Robinson $(1996,92)$ notes, "[t]he countries in which the NED became most involved in the 1980s and early 1990s were those set as priorities for US foreign policy." It is particularly important to note that:

In their trade union operations, US officials employ a double standard. In those countries where "democracy promotion" programs are designed to stabilize pro-United States regimes, the United States encourages allied unions to practice an apolitical "business" unionism focusing on breadand-butter issues at the level of individual employers, and to recognize the overall legitimacy of the social order. But in countries targeted for destabilization, such as Nicaragua, Poland, and Panama in the 1980s, allied unions were encouraged to mount explicitly political actions, and to mount them against governments, not business management (103).

In other words, the character of the activities undertaken by labor (and broadly speaking most NED-allied organizations) is dependent upon the nature of the relationship the foreign state has with the United States.

Polyarchy, also termed "limited" democracy by some has four main indicators.

First, the existence of security forces, whether military or internal security, that are unaccountable to the general electorate. Second, the promotion of the neoliberal program of privatization and foreign direct investment. Third, the presence of elite coalitions linking domestic and transnational capital. Finally, under conditions of polyarchy the state is restructured under the neoliberal model. Moreover, the state becomes the neoliberal model, as linkages with international organizations such as the World Bank 
and IMF are seen as preconditions to democracy (Aviles 2012). Perhaps most interesting, is the circuitous problem facing the democracy promotion program, in that “...the deleterious economic and social consequences associated with neoliberal economic policies (such as privatizations or steep reductions in public welfare programs) creates the conditions for continuing attempts by sectors in civil society to challenge the established order" (Aviles 2012, 230). In other words, even as polyarchy is promoted, the outcome in a limited democracy also creates future fires to extinguish in a selfperpetuating cycle.

\section{Chapter Summary}

At least prior to the creation of the Solidarity Center, throughout the history of the AFL and later the AFL-CIO, there has existed a symbiotic relationship between the U.S. state and the Federation's mission abroad. In the early $20^{\text {th }}$ century, the AFL under Samuel Gompers exported "plain and simple" business unionism through the PAFL, but was generally more concerned with combating German or communist influence than creating labor internationalism. By the end of World War II, the federation was fully engaged with using labor as a tool of U.S. policymakers in order to undermine communist influence in Europe, Africa, Asia, and the Americas. The Federation either fell in line (or determined internally that it was in their best interest to do so) behind the U.S. strategy of containment during the Cold War. As the cases above indicate, when operating inside a country that was a client regime of the United States, the AFL-CIO generally tolerated authoritarian governments and sought merely to minimize leftist influence. The Federation carried out these policies using a variety of means, including 
creating parallel unions to disrupt powerful progressive labor organizations and instructing client unions in the finer points of business unionism. However, when faced with a regime that was deemed unfriendly to U.S. geostrategic or business goals, the Federation was happy to instruct their client unions to engage in overtly political action.

During this time span the AFL-CIO used its four regional labor institutes to back the overthrow of democratically elected regimes and to bolster authoritarian regimes based upon U.S. geostrategic interests. As the Cold War wound to a close and the containment strategy laid out in NSC 68 became less relevant, the NED stepped in as the primary support mechanism for a vision of U.S. foreign policy that viewed "democracy promotion" as a tidier and more palatable version of U.S hegemony. It is only with time and significant efforts by labor activists and scholars that much of the history of the AFLCIO abroad has been unearthed. However, in this dissertation I am concerned with determining how much has changed with the abolition of the regional institutes and the creation of the Solidarity Center in 1997. Has the Solidarity Center opened a new era of AFL-CIO foreign policy? Or has the post-1997 era merely been marked by a strong continuance of the alignment of U.S. state and Federation foreign policy goals? Thus, in the following chapter the Solidarity Center is examined in depth. First, by looking at the conversation amongst labor elites and the debate over the creation of the ACILS, and then later by tracking the specific funding flows from the NED and comparing them with U.S. geostrategic interests. 


\section{CHAPTER III.}

\section{INTRODUCTION}

As the previous chapters have demonstrated, during the Cold War the foreign policy of the AFL-CIO can best be explained by the exigencies of the U.S. state. During the Cold War, American foreign policy was shaped by the strategy of containment as elaborated in NSC 68, and the Federation was more often than not a willing partner in securing client states under American hegemony, and in destabilizing regimes that opposed U.S. dominance. However, this relationship was complex, and not easily explained by a single factor. The labor-state nexus involved multiple linkages, including the history of business-unionist tendencies in the Federation, the symbiotic relationship that encouraged labor to support U.S. foreign policy in exchange for material benefits at home during an era of rising prosperity, and the placement of vehement anti-communists in key labor lieutenant positions.

More importantly for this research, the net result of these interrelated factors was that from the end of World War II until (at least) the early 1990s, the Federation often worked to stabilize friendly regimes, and to destabilize regimes which were not clients of the United States. As was discussed in chapter two this meant working to bolster repressive or dictatorial regimes in El Salvador, Nicaragua, the Philippines, South Korea, Grenada, Haiti, South Africa, Russia under Yeltsin, and Brazil after the military coup of 1964. In each of these cases the foreign policy arms of the Federation encouraged apolitical labor organizations focused solely on collective bargaining and wage and benefit issues. AFL-CIO strategies mirrored U.S. foreign policy in these regions, which 
supported non-democratic regimes in favor of stability and anti-communism.

Conversely, faced with regimes opposed to (or noncommittal towards) U.S. geostrategic interests in places like Guatemala, Brazil, British Guiana, and Chile, the Federation did exactly the opposite; encouraging explicitly political labor organizations and, in many cases, working to undermine and destabilize the regimes in question. In short, when labor organizations acceptable to U.S. foreign policy existed, they received the full support of the Federation's efforts, no matter how marginal the domestic support for these organizations. In cases where existing labor organizations were unsympathetic to these aims, the Federation created parallel unions to back their goals, often with the tacit support of non-democratic regimes.

In this chapter I examine the politics of the formation of the American Center for International Labor Solidarity (ACILS or "Solidarity Center"). Here I inspect the extent to which the post-Cold War period of US foreign policy contributed to a shift in the relationship between the AFL-CIO and the foreign policy bureaucracy of the US state. It was during this period, in 1997, when the AFL-CIO disbanded the four regional institutes described in chapter two, and replaced them with the ACILS. As such, this chapter is the "first cut" in determining whether the AFL-CIO has gone in a more independent direction after the collapse of the Soviet Union? Or whether the current patterns of funding and activities of the ACILS suggest a mirror image of the same pattern of foreign policy behavior?

Therefore, the ensuing chapter is laid out in the following manner. First, I discuss the politics behind the formation of the Solidarity Center by looking at the dynamics of the consolidation and replacement of the regional institutes. In this section, I give a brief 
overview of the debate being waged within labor itself via numerous "clear the air" resolutions regarding the Cold War history of Federation foreign policy, and contrast that with the stated goals of the Solidarity Center. Second, I clearly illuminate the funding linkages between the U.S. state and the Solidarity Center by examining the ACILS budgets from 2002-2010, indicating that just like during the Cold War, the Federation is receiving the overwhelming majority of its funding for its overseas work via the American government and its agencies (such as the National Endowment for Democracy). Examining the funding linkages is a key component in understanding an area of continuity, as the Solidarity Center continues to operate under a budget funded almost entirely by the U.S. state. Finally, I track these funding flows by region, analyzing areas where significant spikes occur and then cross-referencing the operations of the Solidarity Center with these funding patterns and geostrategic events of particular importance to U.S. foreign policy. By using this approach, a more nuanced picture of the relationship between the ACILS and the U.S. state emerges. In short, this chapter highlights the instances where the ACILS has seen significant increases in funding and then links them to areas of particular interest in regard to American foreign policy.

\section{THE SOLIDARITY CENTER CREATION AND EFFORTS TO OPEN THE BOOKS}

As discussed in the previous chapter, the precursors to the ACILS had a historical track record that indicated subservience to U.S. foreign policy goals in regard to much of their overseas activity. Beginning in the 1960s, investigative scholars and journalists began to shed light on the policies of the American Institute for Free Labor Development, the African American Labor Center, the Asian American Free Labor Institute, and the 
Free Trade Union Institute. Though scholars and activists were uncovering evidence critical of the operations of the Federation abroad, the regional institutes continued their work largely unabated through the 1990s. The dominant leadership of George Meany and later, Lane Kirkland, routinely refused to answer any questions about the institutes' activities. In fact, one of the most interesting aspects of studying the foreign policy of the AFL-CIO during the Cold War is the lack of information given by the Federation itself. This led to several movements to "open the books" on the activities of the AFL-CIO abroad, all of which were ignored or squelched by the AFL-CIO leadership.

Critically, neither the activities of the Solidarity Center nor the four regional institutes has ever been opened up to a full review by AFL-CIO members, even though numerous attempts have been made to publicize and shed light on the overseas operations of both the institutes and the ACILS. As early as 1974, labor activist Fred Hirsch publicized information on the AIFLD's role in the CIA-orchestrated coup that overthrew President Salvador Allende in Chile. Ever since, a variety of resolutions have been made to demand a full accounting of Federation foreign policy, including a resolution “condemning AIFLD's involvement” by the South Bay Labor Council (Scipes 2004). The initial resolution was buried for reasons that are unclear (Scipes comments that "other events intervened") (ibid.).

A similar resolution was offered at the California Federation Convention in 2002, in an effort to open the books on not only the Chilean coup, but on all activity undertaken by the foreign policy arms of the AFL-CIO (ibid.). However, this resolution was bypassed when a special delegation of the national AFL-CIO worked out a “compromise". As Scipes notes: 
AFL-CIO representatives were aghast at the "Clear the Air" resolution. The author's sources weren't in the room at the time, but it appears likely that a deal was made whereby the AFL-CIO representative asked the California Federation's Executive Committee to accept a "watered down" resolution (\#20) in exchange for a meeting between the Federation and California activists and leaders from the International Affairs Committee and Department to discuss these issues in a less confrontational manner. Resolution \#20 called upon the AFL-CIO "to convene a meeting with the State Federation and interested affiliates in California to discuss their present foreign affairs activities involving government funds" (ibid.).

The closed door discussion, which took place a year after resolution \#20 was passed, involved members of the AFL-CIO's International Affairs Department (IAD) and International Affairs Committee (IAC) meeting with state-level leaders of the California federation. Barbara Shailor, then head of the IAD, did not attend, but sent a representative in her place. According to interviews with participants (the national AFLCIO leadership allegedly asked for the session to be closed to the public), the representatives of the IAD and IAC argued that "...the past was past, and that efforts to... come clean on these past events would only give AFL-CIO opponents more ammunition to fight unions" (2004). In other words, nothing from the past was discussed and only general outlines of the current operations of the ACILS were broached.

The Federation has been just as guarded since the 2002 meeting in California, refusing to address a similar resolution in 2004. In 2005, Shailor allegedly refused to be interviewed by Amy Goodman on the program "Democracy Now" when she learned labor scholar Kim Scipes and union activist Fred Hirsch (both of whom have been critical of AFL-CIO foreign policy) were going to be present (Scipes 2005). Thus, although the creation of the ACILS has led to optimism amongst various scholars and activists, it 
remains to be seen if this is a new beginning for the foreign policy of the Federation or just more of the same in a different guise.

The creation of the ACILS itself was a by-product of the election of John Sweeney to the Presidency of the AFL-CIO in 1995, and seemed to provide the possible impetus to a shift in the foreign policy of the Federation. Sweeney's "New Voices" slate signaled a new commitment to organizing and an attempt to reverse the troubling trend in de-unionization that had been taking place in the United States since the late 1970's. Labor activists and scholars also read into this occurrence (the first democratic transition in AFL-CIO history) something else: that the New Voices leadership would be willing to confront the foreign policy failures of the past and to turn to a new model of international labor solidarity that would be less tied to U.S. foreign policy goals. Much of this was based upon Sweeney's work with National Labor Committee in Support of Democracy and Human Rights in El Salvador, which involved a group of labor leaders who adamantly opposed AIFLD policies in the Central American nation.

The response to the creation of the ACILS has been largely favorable by many of those who previously were critical of Federation foreign policy. Labor activist and scholar Kim Moody wrote that "[o]ne change that seemed fairly dramatic was the creation of the Center for International Labor Solidarity (CILS) and the simultaneous abolition of the notorious regional Institutes" (Moody 2007, 137). Although Moody also notes the troubling sign that the AFL-CIO may have been involved in the Venezuelan coup that sought to topple President Chavez from power in 2002, he concludes on an optimistic note that "...it seems clear there has been a change" (ibid.). Other scholars also noted hesitant optimism, arguing that Sweeney's election was the product of "a 
broad coalition of union leaders who broke with the former president, Lane Kirkland, over foreign policy. In particular, they disagreed with the AIFLD's support for U.S. policy in Central America and hoped to get rid of what they believed was a cold war relic, "a pro-corporate anti-communist extension of the McCarthyism still dominating U.S. foreign policy" (Shorrock 2003).

In Why Unions Matter Michael D. Yates wrote: "[i]t is to the credit of AFL-CIO president John Sweeney and the New Voice team that the AIFLD and other similar international affairs departments have been abolished. However...the U.S. labor movement may not have completely abandoned AIFLD-like interventions abroad" (Yates 2009). Simon Rodberg, in the most positive piece to be found, notes that the Solidarity Center was largely a byproduct of Sweeney's work with the National Labor Committee in Support of Democracy and Human Rights in El Salvador during the Cold War. Rodberg's piece is partially constructed from interviews with international labor lawyers, who note that Barbara Shailor, the woman picked to head the AFL-CIO's International Affairs Department after the election of the New Voice slate “...gradually weeded out those people who were associated with the old crowd and their Cold War line. They have changed the face of the AFL-CIO" (Rodberg 2001).

In short, labor scholars and activists have been reservedly optimistic that the creation of the Solidarity Center was a step forward in distancing the AFL-CIO from its past record of interventions, support for autocrats, and the corporate-state led agenda. Shailor, wrote that:

The AFL-CIO's new Solidarity Center is designed to assist unions in the developing world in building their capacity to become strong partners. Through cooperative design and implementation of concrete projects, 
unions will better represent their workers in international institutions and with their own governments, at the bargaining table and in organizing. The Solidarity Center was established July 1, 1997 when in consultation with AFL-CIO affiliates, a new Board of Directors, and the International Department were consolidated with the four regional institutes (Mort 1999, 151).

However, Shailor mentions nothing of the controversial work previously undertaken around the world by the AFL-CIO or the underlying logic of the consolidation. Thus, like the Meany and Kirkland regimes before them, the "New Voices" continued the pattern of refusing to account for the past policies of the foreign institutes and the ACILS, one that still continues today under the leadership of Richard Trumka.

\section{The ACILS AND FUNDING}

From the outset of the formation of the Solidarity Center, the main issue has remained the sources of funding chosen and the lack of transparency involved in the funding process. The four foreign institutes (prior to 1997) received the vast majority of their financial patronage during the Cold War through a variety of grant-making institutions and government funded agencies. As described in chapter two, this meant that the AFL-CIO was sometimes involved with the CIA, while at other times receiving funding from USAID (and later the NED). Thus, even the most optimistic pieces regarding the formation of the Solidarity Center allude to the lack of transparency in funding as being a major stumbling block to a radical reorganization of priorities and strategy. The issue of material support is a double-edged sword. Not only does accepting large percentages of funding through various governmental and quasigovernmental agencies possibly compromise the Solidarity Center's independence; it also leads to a situation where the ACILS is dependent on the whims of Washington for its 
existence. In fact, this tension led the AFL-CIO's International Affairs Committee to recommend that the Solidarity Center be "weaned off government funding" altogether (Rodberg 2001). Even the AFL-CIO News wrote that "[t]he committee recommended that ACILS be funded without government supervision, foreign or domestic" (Parks 1996) (as cited by Scipes 2010, 38). Therefore, it is clear that even within the Federation the independence of AFL-CIO foreign policy would always be in question when the institutes or the ACILS were reliant on outside resources.

Nonetheless, these recommendations have largely been marginalized as the Solidarity Center continues to receive the overwhelming majority of its funding from governmental organizations just as it did before the merger and creation of the ACILS. Today, the ACILS receives around $95 \%$ of all of its funding directly from the U.S. state via governmental and quasi-governmental organizations. However, the true nature of the funding patterns for the Solidarity Center is obscured by its rhetoric, which merely claims that the ACILS is "[j]ointly funded by the AFL-CIO, the U.S. Agency for International Development, and the National Endowment for Democracy" (Mort 1999, 151). Further, the mission statement of the ACILS explains:

The Solidarity Center receives funding from both public and private nonprofit sources. Funding sources include the U.S. Agency for International Development, the National Endowment for Democracy, the U.S. Department of State, the U.S. Department of Labor, the AFL-CIO, private foundations, and national and international labor organizations. The American labor movement has supported workers abroad since its founding more than a century ago. Along with other civil society organizations, it has received U.S. government funding to promote the cause of workers and the development of democratic trade unions in countries all over the world. The programs implemented and the partners chosen are determined solely by the Solidarity Center and the AFL-CIO (Solidarity Center Website). 
The final caveat implies that the ACILS operates as an independent agent picking the sources of funding which meet its strategic goals and exercising ultimate discretionary power over projects. But the Solidarity Center's actual overseas involvement is much more complex than the official mission statement claims. As recounted above, the initial recommendation by the International Affairs Committee was that government funding should be phased out completely. This follows logically from the assumption that only without funding from U.S. state-related organizations like the NED, and state bureaucracies like USAID, could the AFL-CIO's foreign policy arm be truly independent.

The assumption about the negative effects of state funding for the ACILS is derived from two separate yet equally important concerns. First, that funding directly through the U.S. state would be tied to direct U.S. foreign policy goals in what could be considered a reversion to the Cold War era practices. Concretely, this could mean a repeat of the period when the four foreign institutes acted in concert with the CIA and U.S. state in order to undermine and destabilize regimes hostile to U.S. interests while supporting authoritarian or non-democratic regimes that were within the U.S. sphere of influence. Second, with the end of the Cold War and a new movement towards "democracy promotion" by quasi-governmental agencies such as the National Endowment for Democracy (NED), the foreign policies of the AFL-CIO would gravitate towards indirect promotion of policies that supported U.S. state goals in a more nuanced manner. For the purposes of this work, the second type of activity, what scholars have termed "democracy promotion" is the dominant, though not exclusive concern, especially considering it seems to be the preponderant strand of interests intertwined with current 
funding patterns. However, both of these typologies of activities have, as a baseline assumption, that what is good for organized labor may not be good for the U.S. state and vice-versa. In other words, scholars and unionists looked to the creation of the Solidarity Center as a breakpoint with past policies and recognized the lack of independent funding as a major concern for policy unilateralism.

Therefore, while many celebrated the (at least cosmetic) alteration of AFL-CIO policy via the Solidarity Center, very few scholars thus far have considered a factual reason behind the elimination of the four regional institutes. As mentioned in the introduction to this chapter, what little is written on the ACILS seems to take at face value the claim that the ACILS was to be an example of the shift away from Cold War era strategies backing the U.S. state towards a more robust form of labor internationalism that could stand up to powerful agents of globalization such as multinational and transnational corporations.

The assumption that the New Voice leadership had a different outlook on labor internationalism and the role the AFL-CIO was to play in the post-Cold War era was largely based upon the rhetoric of the Solidarity Center and its founders. However, even 5 years into its existence, at the 2002 closed-door meeting described by Kim Scipes, the top leadership of the IAD and IAC were still reluctant to discuss alternate funding for the

\section{ACILS:}

In response to the demand that they quit taking US government money-either from US Agency for International Development (USAID) or the quasi-governmental (and Reagan-created) National Endowment for Democracy (NED)--they argued that union members are taxpayers, and that they have just as much right to take government money as any corporation. And in response to the demand that an international work be 
funded only out of AFL-CIO member support, they claimed the affiliates would never support it (Scipes 2004).

All considerations of the legitimacy of questioning whether members would support the use of member funds for overseas operations aside, it is clear that top leadership within the AFL-CIO foreign policy apparatus remains committed to obtaining grant money and funding through the same channels as it used prior to the creation of the ACILS. In itself this commitment raises questions about the direction of the Solidarity Center. As Scipes' report documents, "[t]he AFL-CIO is still taking U.S. Government money from USAID and NED, but provided no amounts from either or on what basis it was provided. Interestingly, they stated that countries where USAID or the State Department had no interests are off limits" (Ibid.). In other words, at least unofficially the ACILS recognizes that their patrons have specific areas of interest in which they are given latitude to operate.

Furthermore, this raises a larger question, of which an answer can only be partially confirmed. That is, was the creation of the ACILS nothing more than a cosmetic change? In other words, did the four regional institutes undergo a "branding" change in order to create a new image? Again, the data on this front is scarce. Previous scholars have repeatedly referred to initiatives within the labor movement, most notably from the New Voice administration that sought to re-focus the energies and efforts of the AFLCIO away from U.S. state goals towards an undefined yet broader set of objectives for labor. Under this common conception, the New Voices slate were given the "benefit of the doubt" without accounting for past practices. 
However, crucially for this research is a document I found that has been previously unnoticed by scholars. The report, dated April 30, 1996, from the United States General Accounting Office (GAO) to Senator David Pryor reveals an intriguing bit of information regarding the creation of the Solidarity Center. The GAO document, from the National Security and International Affairs Division of the GAO describes the funding allocations for AIFLD from "fiscal years 1980 through 1994" where "AIFLD received about $\$ 215$ million, of which USAID provided about 87 percent, the National Endowment for Democracy (NED) provided about 10 percent, the private sector provided about 2 percent and the U.S. Information Agency provided the remainder", therefore reinforcing the notion that the institute was receiving virtually all its assistance from governmental agencies and tax-payer dollars (U.S. General Accounting Office [GAO] 1996, 1). The report points out that over this time period USAID engaged in "at least four external evaluations from 1991 through 1995" and that "AIFLD provided important support to democracy movements in the 1980s but that AIFLD needed to change the programs to reflect post-Cold War political conditions" (GAO 1996, 2). Besides providing crucial information on changes in funding flows prior to the creation of the Solidarity Center, this report makes it clear that the as USAID funding decreased the four foreign institutes (or at least AIFLD) were being pushed towards a restructuring. In other words, while the AFL-CIO presented (or at least implied that) the consolidation and creation of the Solidarity Center was a new beginning for the federation's foreign policy, it appears quite possible that this impetus came not from within the labor movement or the New Voice administration, but from the agencies and 
organizations that controlled the purse strings. Further down in the report this becomes

quite specific:

In response to decreasing funds, USAID is encouraging the AFL-CIO to consolidate its regional institutes into a new single global institute and to set strategic objectives globally and within specific regions. According to an AIFLD official, the AFL-CIO has set in motion plans to consolidate its regional institutes. According to a USAID official, this consolidation is scheduled to take effect around January 1, 1997, and will conform to USAID's own efforts to improve oversight of labor programs as well as to manage and allocate resources in line with agency priorities (GAO 1996, 8).

Therefore, there is some reason to question the actual storyline behind the creation of the Solidarity Center. That is, if in fact the ACILS was created not through a cathartic vindication of past policies but rather through the urging of benefactors we should not be surprised to see the repetition of past policies via the Solidarity Center. Given that the preceding sections indicated that the Federation would still rather not discuss the particulars of foreign policy, past or present, or open the books, we should be wary of doubting that AFL-CIO foreign policy is not best explained by this relationship with the U.S. state.

\section{THE SOLIDARITY CENTER AND THE NED}

As should be clear by now, the relationship of the Solidarity Center (as with the previous institutes) with its benefactors is very difficult to decipher. Even after multiple resolutions demanding a full accounting of Solidarity Center activity and funding, the AFL-CIO has refused to open the books. The Center does publish its annual reports online. However these only date back to 2003, leaving six years of ACILS history blank. Moreover, the reports are vague as to the exact grants which have been funded and which 
agencies or organizations granted the monies. The exact reason for this secrecy is unclear. But very few rank-and-file members of the AFL-CIO have any idea that the Solidarity Center exists, much less what types of activity it engages in.

Table 3.1 2010 Solidarity Center Funding Report

\begin{tabular}{|c|c|c|}
\hline Support and Revenue & 2009 & 2008 \\
\hline Federal awards & $\$ 28,875,063$ & $\$ 28,475,408$ \\
\hline $\begin{array}{l}\text { In-kind contributions for } \\
\text { federal awards }\end{array}$ & 611,595 & $1,080,361$ \\
\hline $\begin{array}{l}\text { Contribution from the } \\
\text { American Federation of } \\
\text { Labor and Congress of } \\
\text { Industrial Organizations } \\
\text { (AFL-CIO) }\end{array}$ & 600,000 & 600,000 \\
\hline Other contributions & 62,522 & 106,208 \\
\hline Interest income & 145,372 & 130,279 \\
\hline $\begin{array}{l}\text { Net appreciation } \\
\text { (depreciation) in fair } \\
\text { value of investments }\end{array}$ & 5,714 & $(17,299)$ \\
\hline Other revenue & 82,818 & 189,058 \\
\hline $\begin{array}{l}\text { Total support and } \\
\text { revenue }\end{array}$ & $30,383,084$ & $30,564,015$ \\
\hline
\end{tabular}

\section{Expenses}

Program expenses

$24,545,582$

$24,953,220$

Indirect expenses

$5,919,606$

$5,764,953$

Total expenses

$30,465,188$

$30,718,173$

\section{Change in Net Assets}

$(82,104)$

$(154,158)$

\section{Source: Solidarity Center 2010 Annual Report}


In order to flesh out the details, sources and sums of funding have to be extrapolated from a variety of sources. Figure 3.1 is an exact replica of the funding breakdown found in the most recent (2010) Solidarity Center Annual Report. Covering fiscal years 2008 and 2009, it gives only the briefest summary of aggregate totals for Federal and union funds used during the fiscal year, without breaking them down by grantor, region, country, or mission. One piece of information is overwhelmingly clear however, and that is Federal funds account for the overwhelming majority of ACILS resources. For example, in 2009 this data indicates that $95 \%$ of all the "support and revenue" the ACILS received was from "Federal awards." To be clear, all available data indicate that 95 cents out of every dollar is coming directly from the U.S. state via quasigovernmental bodies like the NED or US agencies such as the Agency for International Development.

The rest of each Annual Report from 2003-2010 is basically a glossy magazinestyle overview of selected projects in various countries. Clearly, the ACILS is engaged in some meaningful activities related to labor internationalism and is working to combat some of the worst excesses of the neoliberal program. For example, the ACILS has worked to combat sweatshops by organizing boycotts of corporations that use sweated labor utilizing a variety of groups, including student movements and human rights organizations (Quan 2008). However, there is a disconnect between many of the stories covered in the ACILS Annual Report and the amount of funding that is received each fiscal year. While the annual reports extol things like campaigns to work on AIDS awareness, it neglects to mention that in 2004 the ACILS received a million dollars via the NED to work in Iraq. Again and again, an examination of the ACILS reports indicate 
little relation to the patterns of funding, nor to the amount of funding being doled out by specific government agencies.

Therefore, although the Solidarity Center is non-committal about publishing an accounting for its activities, the Annual Reports do give some useful information about aggregate funding and a broad breakdown of where the funding flows may have originated. Specifically, in order to piece together a more detailed picture of the Solidarity Center undertakings, this data can be cross-referenced with data from the National Endowment for Democracy, which publishes annual reports also, but with specific breakdowns for the country and/or region of each grant it funds. Because the Solidarity Center is one of the "core" grantees, this information is available and more detailed than the reports published by the ACILS itself. By comparing NED and ACILS reports it is possible to put together a more sophisticated picture of what types of grants the NED is funding through the Solidarity Center and to determine what percentage of ACILS finances are related to the National Endowment for Democracy.

The relationship between the ACILS and the NED is significant and growing in importance. As indicated in figure 3.2, which looks at aggregate funding for the ACILS via Federal and NED funding, the relationship has become more critical during the time period for which data is available. Federal funding increases slightly from approximately $90 \%$ to about $95 \%$ of ACILS revenues throughout the period. However, NED funding as a percentage increases nearly every year, beginning at $17-18 \%$ of all ACILS finances in 2002-2003, then increasing between 6 and 10\% each year until 2006, where it somewhat plateaus at around 45\%. By 2009, the NED accounts for nearly 1 out of every 2 dollars spent by the Solidarity Center. Although not shown in figure 3.2, during this same period 
of time, AFL-CIO donations to the ACILS remains fairly constant at around 4\% (or $\$ 600,000)$ a year; a paltry sum considering the significant amounts of grants awarded each year for the work of the Solidarity Center. Therefore, it is increasingly clear that the NED is one of, if not the, significant source of Solidarity Center funding. At nearly $50 \%$, it is likely the dominant guarantor of ACILS income.

Table 3.2 Solidarity Center-NED Funding 2002-2009

\begin{tabular}{cccccc}
\hline Year & $\begin{array}{c}\text { "Federal } \\
\text { Funds" }\end{array}$ & Total & $\begin{array}{c}\text { Federal } \\
\text { Funds as a } \\
\text { \% }\end{array}$ & NED Funds & $\begin{array}{c}\text { NED } \\
\text { Funds } \\
\text { as a \% }\end{array}$ \\
\hline $\mathbf{2 0 0 2}$ & $\$ 27,003,253$ & $29,742,621$ & $\mathbf{9 0 . 7}$ & $5,169,002$ & $\mathbf{1 7}$ \\
$\mathbf{2 0 0 3}$ & $29,471,075$ & $32,832,890$ & $\mathbf{8 9 . 7}$ & $6,168,353$ & $\mathbf{1 8}$ \\
$\mathbf{2 0 0 4}$ & $29,351,436$ & $31,707,115$ & $\mathbf{9 2 . 5}$ & $7,803,506$ & $\mathbf{2 4}$ \\
$\mathbf{2 0 0 5}$ & $29,116,549$ & $31,707,115$ & $\mathbf{9 1 . 8}$ & $10,510,022$ & $\mathbf{3 3 . 1}$ \\
$\mathbf{2 0 0 6}$ & $29,584,532$ & $32,058,763$ & $\mathbf{9 2 . 2}$ & $13,729,011$ & $\mathbf{4 2 . 8}$ \\
$\mathbf{2 0 0 7}$ & $27,373,150$ & $28,723,827$ & $\mathbf{9 5 . 2}$ & $12,291,044$ & $\mathbf{4 2 . 7}$ \\
$\mathbf{2 0 0 8}$ & $28,475,408$ & $30,564,015$ & $\mathbf{9 3 . 1}$ & $14,177,341$ & $\mathbf{4 6 . 3}$ \\
$\mathbf{2 0 0 9}$ & $28,875,063$ & $30,383,084$ & $\mathbf{9 5}$ & $13,710,272$ & $\mathbf{4 5}$ \\
\hline
\end{tabular}

\section{Source: ACILS Annual Reports and NED Annual Reports 2002-2009}

The information above alone provides little context for the broader relationship between the Solidarity Center, the NED, and the "democracy promotion" agenda described in the previous chapter. But the NED reports offer much more detail than the ACILS reports. Specifically, these reports list the amount, region or country, and at least a brief description of the work to be performed, for each grant awarded by the NED. By 
tracking the flow of funding along with the specific purpose of each grant, some interesting conclusions can be gleaned. As will be detailed below, for several major regions and/or countries there are significant spikes in NED funding allocation for the ACILS in areas of specific geostrategic concern for the United States.

By examining these patterns, it becomes clearer that the creation of the Solidarity Center did not necessarily mean a shift away from "following the flag" towards a more internationalist conception of the AFL-CIO's international role. Rather than moving to confront the harsh effects of globalization and the increasing power of MNC's, a significant portion of Solidarity Center grants from the NED seem to follow (or at times precede) major U.S. foreign policy actions. The following section will detail some of the specific grants, broken down by region; with an emphasis on those that show substantial shifts in concert with action by the U.S. state. In chapter four, a more rigorous case-study analysis will be conducted to examine the dynamics of these shifts. However in order to deduce exactly how the funding mechanisms work and to make linkages between U.S. foreign policy and the activities of the Solidarity Center, we must first focus on broad patterns. The earliest records coincide with the first year the Solidarity Center published an accounting of its finances (2001), since no records can be found prior to that fiscal year.

\section{ACILS-NED EUROPEAN GRANTS 2001-2009}

The NED funding for Solidarity Center work in Europe is of particular interest at the beginning of the $21^{\text {st }}$ century. Beginning with the earliest available accounting, in 2001 the ACILS received \$507,134 for work in Central and Eastern Europe, including 
Bosnia-Herzegovina, Macedonia, Kosovo (Yugoslavia), and Serbia (Yugoslavia). The largest of these grants $(\$ 163,630)$ was earmarked for Serbia, where it was used in conjunction with the independent union UGS Nezavisnost, to provide offices and training for its members with a focus on "...basic education on the role of democratic trade unions... and to promote local participation in pro-democracy campaigns" (NED 2001). In addition, another $\$ 93,957$ grant was given to develop "policy consensus on education reform, including education on democracy and minority rights" in Albania, Macedonia, Bosnia, Croatia, Montenegro, and Serbia (Ibid.).

In 2002 , this funding fell to $\$ 255,033$, with roughly half of the funds going to Bosnia-Herzegovina, and the other half to Serbia to again be used in the ACILS' work with UGS Nezavisnost, in this case for helping the union "achieve full financial stability" among other things (NED 2002). In 2003, the NED authorized a combined $\$ 156,790$ for grants in Albania and Bosnia-Herzegovina, along with three separate regional grants (totaling \$294,840) for Central and Eastern Europe. By far the largest of these $(\$ 171,920)$, was specifically for increasing the "economic literacy" of workers in Serbia, Montenegro, and Macedonia, so they could "participate" in the reform process (NED 2003). In 2004, NED funded grants for ACILS work in Central and Eastern Europe begins to dry up. In 2004 a single grant $(\$ 111,748)$, was earmarked for Serbia, Montenegro, and Macedonia, to “...improve the economic literacy of trade union leaders and activists..." in the region (NED 2004). In 2005 Kosovo received the only grant $(\$ 60,000)$, and in 2006 a final grant for the region was funded by the NED, for $\$ 71,098$ to “...support the development of the new Confederation of Free Trade Unions (KSS) in 
Macedonia" (NED 2005; 2006). To date, the NED has not funded any more Solidarity Center projects in the region.

Therefore, what the NED refers to as "Central and Eastern Europe" for purposes of its grants from 2001-2006, were in fact applied almost exclusively to the states that make up the former Yugoslavia. At least on its face value, this relationship between funding and U.S. geostrategic aims seems to mirror to patterns observed during the Cold War. There is little evidence to indicate that the role of the ACILS in this era had much to do with organizing workers. Rather, the financing of the ACILS by the NED in the Balkans seems to mirror the U.S. and NATO involvement in the region: seeking to bolster anti-Milosevic sentiments and preparing the region for the economic changes that accompanied the breakup of Yugoslavia.

Though NED and ACILS data is only available from 2001 on, scholars and activists have described the activities of the Solidarity Center in the Balkans as early as 1999. As Judy Ancel made clear in 2000, the "NED has been pouring money into Yugoslavia to strengthen opposition political parties for years. Part of its funding goes to ACILS which assists UGS Nezavisnost, a trade union confederation which opposes Milosevic" (Talbot 1999) (as cited by Ancel 2000). Further:

Whether any of these programs advance international worker solidarity is irrelevant. By accepting U.S. government money and oversight, ACILS cannot possibly have and will not be perceived to have an independent labor perspective. It is compromised, and complicit with U.S. foreign policy goals that by no means can be seen as worker-friendly. Even when they oppose a racist dictator like Milosevic, they are implicitly tied to the U.S. and NATO agenda in the former Yugoslavia, an agenda which by destroying the Serbian economy, will open it to neoliberalism and largescale privatization (Ancel 2000, 32). 
The significant amount of funding targeted specifically for the UGS Nezavisnost (one of only a handful of unions mentioned specifically in the NED reports, and by far the largest recipient of resources) is particularly interesting. Nezavisnost (meaning "independence") was formed in 1991, during the first of several conflicts that eventually shattered Yugoslavia, and "... adopted a deliberate strategy of autonomy from the state and independence from political parties" (Upchurch 2006, 51). Importantly, as Upchurch notes:

In effect, despite remaining independent of political parties, the union has developed a sophisticated political programme following internal debate. Political debate within the union had been spurred by the publication of various documents discussed at a series of education schools for union activists. Assistance in financing the schools was provided by the European Trade Union Confederation (ETUC) and the International Confederation of Free Trade Unions (ICFTU), to which the union is affiliated, as well as the American AFL-CIO (Ibid. 52).

The "programme" is best described in Nezavisnost's own words, and indicates agreement on a wide range of issues that would be of particular importance to the U.S. state. Among these, the labor organization maintained that “...we must do our best to bring Yugoslavia back into the UN, IMF, get closer to the EU, World Bank and other international institutions" (Peace and Crises Management Foundation 2012). Further, the union proposed a government of "experts" (technocrats) that fall squarely in line with the type of democracy promotion activities the NED and its affiliates have championed since inception. Specifically, the groups statement of principles argues that "[i]t is highly important for the government of experts, as the government in the transitional period, to have people who have confirmed their abilities in the economy, particularly in the international competition where the strict laws of market economy set the rules of the 
game" (Ibid.). In other words, at first glance the linkages between Nezavisnost and the Solidarity Center met two critical criteria: antagonistic towards Milosevic and supportive of foreign investment and market reforms. These stances placed Nezavisnost perfectly in line with U.S. foreign policy towards Yugoslavia during this period.

Finally, the fact that NED funding of ACILS programs in this region went from over $\$ 500,000$ in 2001 to $\$ 0$ in 2006 indicates that the organizing the ACILS was engaged in was either a smashing success, or, more likely, a response to the shifting focus of the U.S. state from the Balkans to other regions as the "war on terror" and oil securitization took priority. With Milosevic removed and the states of the former Yugoslavia ensconced in the neoliberal orbit, the NED saw little reason to fund (and perhaps the ACILS saw little reason to ask for funding for), projects in the region.

Other areas of Europe also saw a significant amount of NED-ACILS activity during the period under review. In particular, the Ukraine, Russia, and the "Eurasian" region (including Kazakhstan, Kyrgyzstan, Uzbekistan, Tajikistan, and Georgia) all saw spikes in Solidarity Center activity that correlate with significant shifts in U.S. foreign policy. With the lone exception of 2007, Ukraine in every year under review received funding for ACILS activities. In 2001, this only amounted to $\$ 180,739$, however in 2002 the NED grant for the Solidarity Center in Ukraine jumped to $\$ 4399,967$ and (with the exception of 2007) would increase or hold steady every year through 2009, when it received the largest grant to date ( $\$ 540,000)$ (NED 2001-2009). The Ukrainian case is particularly interesting, although there is very little scholarship on the subject pertaining to the Solidarity Center; this time-period coincides with the "Orange Revolution" of 
2004-2005, which saw a massive round of protests and accusations that Western powers (particularly the United States) were behind the demonstrations and unrest.

Perhaps similar patterns were emerging in Russia. As discussed in the previous chapter, the AFL-CIO was involved in a stabilization campaign immediately following the end of the Cold War, when privatizations and "shock therapy" led to a dramatic decrease in the standard of living for Russian workers. However, in the period under review here, the Solidarity Center wasn't awarded any NED grants for work in Russia until 2006 and 2007, when it received a $\$ 100,000$ grant each year (NED 2006; 2007). However, that number jumped drastically in 2008 and 2009, when the ACILS received grants of $\$ 455,000$ and $\$ 300,00$ respectively (NED 2008; 2009). Although speculative, this does coincide with the Russian election of 2008.

Finally, the "Eurasian" region has seen a significant surge in NED-funded Solidarity Center grants that appear to be closely tied in to U.S. geostrategic moves for oil securitization. Beginning in 2003, grants were given for "regional" work in Kyrgyzstan, Kazakhstan, and Uzbekistan to the tune of $\$ 94,407$. Also included in 2003, was a country-specific grant for Kazakhstan for $\$ 136,447$ to “...implement an introductory union-education program for national and local union leaders" that was targeted for seminars on "...the ways in which unions engage in effective advocacy in a democratic environment" (NED 2003). In 2004, Kyrgyzstan was targeted with a large grant $(\$ 369,744)$ to “...introduce concepts of trade unionism to leaders from the Kyrgyzstan Trade Union Federation at the national, branch, regional and local levels" (NED 2004). 
By 2005, the Eurasian region was flush with cash from NED funded Solidarity Center grants for work in the region. That year, the NED gave two "regional" Eurasian grants. Both were for Kyrgyzstan and Kazakhstan and together accounted for a total of $\$ 717,938$, although one consisted of "reprogrammed funds from 2004" (NED 2005). The fiscal year of 2006 allotted only a single grant for these two nations, for $\$ 350,000$, however it also included for the first time funding for Georgia, which received Solidarity Center funding to the tune of $\$ 151,000$ for, among other things, to expand the Georgia Trade Union Confederation and to provide seminars on “....trade unions in a market economy” (NED 2006). In 2007, NED grants for ACILS work in Georgia totaled $\$ 200,000$ with the goal of training recruiters who could increase union membership (NED 2007). While that same year, funding for Kyrgyzstan and Kazakhstan received funding for $\$ 350,036$ (Ibid.). By 2008, Tajikistan had been included in the regional grant for Kyrgyzstan and Kazakhstan (NED 2008). In 2009, Georgia and Kyrgyzstan both received specific grants for $\$ 249,999$ and $\$ 214,999$ respectively (NED 2009).

Thus, these NED-funded Solidarity Center grants again places the ACILS at the forefront of U.S. foreign policy strategy. As Stokes and Rafael note, this region saw significant activity by U.S. military and intelligence due to its vast oil and natural gas reserves during this period, as China, Russia, and the U.S. sought to securitize their energy supplies (Stokes and Rafael 2010). Moreover, as Dr. Ronald Cox and I noted in 2012, citing Stokes and Rafael:

In fact, the US was working closely to implement neoliberal foreign policies in Kazakhstan in an effort to improve the climate for foreign corporations to gain access to oil and natural gas reserves in the country. These policies contributed to a growing gap between rich and poor, and the Solidarity Center's presence was considered part of US efforts to gain 
ideological legitimacy in the region. The case of Georgia is very telling of the overall approach, as NED/Solidarity Center activities were part of a US foreign policy effort to strengthen the anti-Russian regime through a network of civil society organizations receiving State Department funds (Cox 2012, 70).

Thus, again we see more evidence that the ACILS in conjunction with the NED at least appears to be following the lead of the U.S. state in structuring its activities abroad.

\section{ACILS-NED MIDDLE EAST \& NORTH AFRICA (MENA) GRANTS 2001-2009}

Running concurrent with diminishing funding for their operations in Central and Eastern Europe and increasing resource flows in the Eurasian region, there is a significant spike in the level of funding for the Middle East \& North African (MENA) for the Solidarity Center. At the same time as the Second Gulf War begins in earnest in 2003, ACILS funding via the NED explodes. For example, in 2001, the region was awarded a single grant of $\$ 144,412$ meant to encompass work in Jordan, Lebanon, and Morocco (NED 2001). In 2002, \$291,930 was "reprogrammed" for "workers to participate in the building of democracy in Middle East Unions, workplaces, and society" (Cox 2012; NED 2002). By 2003, Jordan was identified as a desired regional center of ACILS activity and awarded $\$ 560,000$ for work in surrounding MENA countries, and $\$ 300,000$ to work with the ICFTU office in Amman (NED 2003). Thus, overnight some $\$ 860,000$ was granted for Solidarity Center activities in 2003 for working “...bilaterally and multilaterally with labor organizations and likely allies in Jordan, Lebanon, Yemen, Bahrain, Kuwait, and potentially Iraq to address democracy building, transparent unions, and building advocacy skills among workers to represent their interests" (Cox 2012; NED 2003). 
The significant jump in MENA region funding in 2003 was just the tip of the iceberg in regard to NED funding of Solidarity Center programs. With the U.S. military action against the Hussein regime in Iraq in 2003, the following fiscal year showed an exponential increase in funding allocations for the MENA region. In total, the NED allocated nearly $\$ 2.7$ million for operations in the Middle East following the overthrow of the Iraqi regime. Thus, in 2004 the NED "reprogrammed" funding of $\$ 199,933$ from 2003 to "establish an Egyptian Trade Union Technical Organization (ETUTO)..." that would "work with the Egyptian Trade Union Federation in creating the ETUTO" (Cox 2012; NED 2004). Most critically, the Solidarity Center received $\$ 1,498,014$ for use in Iraq to help build labor organizations following the invasion (NED 2004). On top of this, another $\$ 597,045$ "regional” grant was funded "to strengthen democratic trade unionism in the Middle East" in Jordan, Egypt, Yemen, Lebanon, the West Bank and Gaza, along with $\$ 364,755$ for working with the ICFTU in developing labor officers in Jordan, Palestine, Lebanon, and Yemen (Ibid.).

In 2005 funding for the MENA region continued to rise, as the ACILS received $\$ 3,386,501$ in grants from the NED, an amount that made up 32\% of all NED-ACILS funds in that fiscal year (Cox 2012; NED 2005). Among these was an odd grant for Iran (the only Iranian grant funded by the NED in this period), to the tune of $\$ 185,000$ "to support the emergence of a sustainable labor movement" (Ibid.). In addition to several large regional grants, Iraq was again singled out for another \$1 million to develop “democratic" trade unions (NED 2005).

In 2006 MENA total funding for the region was $\$ 3,481,610$, and included the first grant during this period for Afghanistan: $\$ 164,885$ for workers education; as well as two 
other grants specifically for Iraq totaling $\$ 933,481$ (NED 2006). Other countries targeted in 2006 included Jordan, Libya, Tunisia, Gaza and the West Bank. Finally, 2007 was the apex of NED funding of the Solidarity Center in the MENA region. In 2007, a total of $\$ 3,408,092$ was doled out for work in Afghanistan, Bahrain, Jordan, Gaza and the West bank, as well as the "Maghreb Region" (NED 2007). Also in 2007, the ACILS received its last grant for work in Iraq, for $\$ 1,500,001$ (Ibid.).

The pattern that emerges from the data mirror in many was what was observed with NED-ACILS activities in the Balkans, that is funding for the Solidarity Center closely tracks with U.S. foreign policy leading up to the invasion and occupation of Iraq as part and parcel of the wider "war on terror". As Ronald Cox and I argued previously, although the official position of the AFL-CIO was to oppose the invasion, the Solidarity Center worked with the occupying forces, directly contradicting their public statements

as:

...the rules of US military engagement in Iraq required all US organizations to be given authorization for all political activities inside the country. As with other US organizations active in Iraq, including the media, the US Solidarity Center would be embedded with US military troops as a precondition for its activities. These ground rules, by definition, would limit the ability of a group receiving US State Department funding from taking an anti-occupation stance. In fact, the position of the Labor Solidarity Center in Iraq, faced with conditionalities that required them to be an adjunct of the US occupying authorities, clashed rather jarringly with the position of large numbers of activists and unions inside the US that formed organizations opposed to the war (Cox 2012, 71).

Further, as organizations like the Worker to Worker Solidarity Committee reported at the time:

...the Solidarity Center plays an active role backing a US occupation despised by Iraqi workers. It recognizes only one of several union centers. 
That federation is the only center participating in the government empowered by the Bush Administration, and the only one to state support for the occupation. Choosing to support one union over others violates the AFL-CIO's own primary principle recognizing the rights of workers to choose who will represent them. That principle is called "Freedom of Association" (Worker to Worker Solidarity Committee 2006).

In other words, the activities of the ACILS in Iraq was reminiscent of past federation foreign policy; privileging labor organizations that supported U.S. geostrategic goals over others and working with groups aligned with the NED to restructure the Iraqi economy post invasion.

In addition to the focus on Iraq, there are also similar patterns in Solidarity Center activities in Egypt, where NED-ACILS funding begins to appear in 2004. By 2009, the ACILS was the recipient of $\$ 318,757$ in grants to support "freedom of association" in Egypt (NED 2009). As Cox and I pointed out (citing Bolton 2011 and Barker 2011):

The NED funds that supported Solidarity Center union-organizing in Egypt were simultaneously being used to privatize state-owned industry, build support for neoliberal reforms and fund the Center for International Private Enterprise, a group representing foreign transnational firms who wanted to expand their operations in the Egyptian economy. Here Solidarity Center activities, while laudably supporting the right of Egyptian workers to strike for better pay and working conditions, were closely tied to a range of political activities intended to support a corporate globalization agenda (Bolton 2011; Barker 2011) (as cited by Cox 2012, 72).

Again, this is just a brief examination of funding patterns, which will be further elaborated upon in the following chapter. However it does continue to reinforce the notion that the foreign policy of the AFL-CIO is squarely in line with the agenda of the U.S. state. 


\section{ACILS-NED LATIN AMERICAN AND CARIBBEAN GRANTS 2001-2009}

The previous chapter indicated that the majority of the research and investigation into the foreign policy of the AFL-CIO has centered on Latin America and the Caribbean. Scholars and activists uncovered a wide-range of activities in the region during the Cold War that indicate, in line with U.S. geostrategic aims, the Federation often supported non-democratic client regimes of the U.S., while at other times working to overthrow regimes that refused to align with American foreign policy. As discussed earlier in this chapter, many argued that it was the pushback of Federation's members regarding AFLCIO policy in Latin America specifically that led to the creation of the ACILS to replace the four foreign institutes. Unfortunately, the linkages between the ACILS and the NED in their "democracy promotion" activities from 2001-2009 raise many more questions regarding whether or not there has in fact been a change in Federation foreign policy.

Of particular concern is Solidarity Center activities in Venezuela, where in 2001, two grants were funded by the NED for ACILS use. The first was for $\$ 154,377$ to "protect labor rights" (NED 2001). The second was a larger regional grant, which included Peru, Colombia, Ecuador, Bolivia, and crucially Venezuela, to the tune of $\$ 622,800$ (Ibid.). Similar grants were funded in 2002, with Venezuela specifically receiving $\$ 116,001$ to support the Confederation of Venezuelan workers by “...developing a program to extend organization, training, and representation to the informal sector. ACILS will also aid the Confederation in developing and publicizing its positions and strategies on economic and social issues as part of the development of an antipoverty program" (NED 2002). Another larger regional grant (for the "Andean" region) for $\$ 775,001$ was aimed at promoting democracy on "economic and political" 
fronts (Ibid.). As Ronald Cox and I noted previously: "[i]nterestingly, both the 2001 and 2002 grants for Venezuela were marked with an asterisk, which is identified in other NED Annual Reports as indicating that the funding for these grants was allocated by the by the U.S. Department of State beyond the annual NED appropriation" (Cox 2012, 72).

These earmarked funds are of particular interest as the activities of the NED and ACILS leading up to and during the attempted 2002 coup in Venezuela have been well documented. As Scipes (2006, 2010), Gollinger (2006), and others have noted, the Solidarity Center was linked to a variety of groups that participated and played integral roles in the brief coup. The Venezuela case will be discussed in greater detail in the subsequent chapter, however this episode most closely resembles the type of destabilization activities that AIFLD became notorious for during the Cold War in places like Chile and Brazil.

Following the exposure of NED-ACILS involvement in the 2002 coup, the Solidarity Center has not received any Venezuela-specific grants. Yet, Venezuela is implicitly included in the increasingly large grants for the "Andean" region thereafter. In 2003 for example, the NED funded two Solidarity Center grants for Latin America: a small grant of $\$ 40,000$ to "promote labor rights in the Inter-American human rights system", and a large grant of $\$ 774,893$ for the Andean region (NED 2003). In 2004, there was only one grant authorized by the NED for Solidarity Center use, again focusing on the Andean region, for $\$ 736,800$ to promote “democratic" trade unions (NED 2004). However, starting in 2005 Latin America as a region begins to see much larger "regional" grants (a total of $\$ 1,499,967)$, in addition to country-specific grants in Mexico $(\$ 183,315$ ) and, crucially Haiti, where $\$ 99,965$ was given by the NED to the ACILs to work with the 
Batay Ouvriye (NED 2005). The relationship between the ACILS and Batay Ouvriye has been discussed by other scholars, including Jeb Sprague (2007), who argued that ACILS support of Batay Ouvriye was solely related to the militant anti-Aristide sentiments displayed by the organization (Ibid.).

In 2006, the Solidarity Center received $\$ 1,759,238$ for four regional Latin American grants as well as a country-specific grant for Mexican auto-workers (NED 2006). 2007 looked much the same, with the NED allotting $\$ 2,069,238$ for the ACILS in four regional grants as well as another grant for Mexican laborers employed in the auto industry (NED 2007). The 2008 NED report lists $\$ 2,724,001$ in Latin American grants for the Solidarity Center, including $\$ 250,000$ earmarked for Haiti "to build strong, representative trade union organizations guided by workers' interests both internally and as actors in Haitian democracy" (Cox 2012; NED 2008). Finally, in the last year data is available, we see again in 2009, ACILS grants for Haiti jumped to $\$ 300,000$ (NED 2009). The case of Haiti is especially intriguing, and will be discussed in the following chapter, as it indicates a continuity of AIFLD like behavior by the successor Solidarity Center. As noted in the preceding chapter, during the dictatorial Duvalier regime AIFLD worked to set up pro-regime labor organizations that would satisfy the requirements for the Caribbean Basin Initiative. Federation strategy later shifted in Haiti in line with U.S. foreign policy goals after the election of Jean-Bertrand Aristide in 1990, where AIFLD policy switched to one of de-stabilization (Cox 2012, 74). As Sprague notes, with the reelection of Aristide in 2000, the ACILS worked with the NED and USAID “...to support opposition groups in Haiti, including the Convergence Démocratique, an internationally financed and trained organization of opposition parties in Haiti which had strong 
connections to CIA-sponsored death squads, the International Republican Institute and pro-Duvalierist opponents of Aristide that were working to remove him from office (Sprague 2007) (as cited by Cox 2012, 74). Sprague also details the relationship between Batay Ouvriye, a radical syndicalist union, and the ACILS, which revolved not around the conditions of workers in Haiti, but on the militant anti-Aristide sentiments of Batay Ouvriye (Ibid.).

Thus, the rough contours of Solidarity Center funding via the NED in Latin America indicate continuity with past AIFLD practices. First, the ACILS has seen significant activity in Latin America, specifically in regions (the Andes) where antineoliberal movements and leaders have emerged. Thus, the area of primary concern for the NED-ACILS has been in an area where a crop of leaders, including Hugo Chavez, Rafael Correa, and Evo Morales, pushed back against the policies of the United States. Second, the ACILS has been implicated in at least one attempted coup (Venezuela 2002) that received prominent attention from scholars and activists. Finally, the relationship between the Solidarity Center and labor organizations in Haiti is also highly suspect, and likely included activities designed to destabilize the Aristide regime.

\section{ACILS-NED ASIA AND CHINA GRANTS 2001-2009}

Solidarity Center activity in Asia generally, and China in particular, makes for an interesting case study. In many ways, Asia stands as the symbol of the loss of manufacturing jobs in the United States as increasingly corporations are off-shoring their labor to places like China and Taiwan in an effort to push down production costs. Though these practices are becoming more sophisticated, involving global "value chains" 
where production is dispersed across several states, Asia stands out as one of the main locations where (formerly) high-paid U.S. manufacturing jobs have landed. Thus, as union density continues to decline in the private sector in the United States, Asia would seem to be a prime location for the Solidarity Center to focus its efforts of international solidarity. However, as will be discussed briefly below (and more at length in the following chapter), the countries targeted for ACILS activity in Asia demonstrate that the Solidarity Center operations are often still related to U.S. geostrategic aims.

In examining the data available via NED reports and ACILS summaries, it is clear that from 2001-2009 the Solidarity Center received significant funding for operations in Asia. As the NED has continued to account for more of the overall ACILS grants, Asia has received more and more funding, especially country-specific grants in China, Burma (Myanmar), and Pakistan. For example, in 2001, Solidarity Center funding for Asia amounted to $\$ 1,908,388$ (NED 2001). Those grants were dispersed primarily for work in Burma $(\$ 456,699)$, China $(\$ 430,911)$, and Pakistan $(\$ 207,767)$, along with regional grants including a large amount of funding $(\$ 523,047)$ for Malaysia and Thailand (Ibid.). Fiscal year 2002 looked very similar in terms of funding, while in 2003 funding directed solely at China jumped up to $\$ 790,201$ out of the NED-Solidarity Center Asia budget of $\$ 2,073,298$ (NED 2003). Also Sri Lanka, Pakistan, and Burma again received large country-specific grants in 2003, a pattern that continues throughout the period under review. During the five-year period from 2004-2009, ACILS grants via the NED continue to grow each year, however they remain fairly evenly focused on just a handful of nations: China, Pakistan, Sri Lanka, Malaysia, Thailand, and crucially Burma. 
Thus, the Solidarity Centers activities in Asia are a mixed bag. In China, as Quan (2008) argues, the ACILS has done some valuable work in linking various NGOs and student groups to help combat sweated labor. In Pakistan, the Solidarity Center works to eliminate human trafficking and further the rights of women workers. On the other hand, ACILS work in Burma is consistently among the largest grants given, yet is related more to democracy promotion than to labor issues. In both China and Burma there is some evidence that ACILS and NED policies have more to do with U.S. geostrategic goals than with organizing workers or supporting international labor solidarity. As the AFL-CIO consolidated its foreign institutes into the Solidarity Center in 1997, Ciment and Ness argued that:

With or without the AFL-CIO, the NED continues to serve American foreign policy, funding organizations that promote economic restructuring, undermine workers' rights, and increase layoffs, while paying lip service to labor rights. In China, it funds organizations that encourage privatization and train employers in anti-labor strategies. Moreover, in 1997, while the NED offered extensive funding for an American-inspired free labor development in Burma, it provided no support for a grassroots labor movement in American ally Indonesia under Suharto, the recently deposed dictator of 33 years, where workers have actively sought to organize independent trade unions and whose leader languished in jail (1999).

Moreover, NED-Solidarity Center grants for Nepal (following on the heels of the end of the Nepalese monarchy) are also suspect. In the Nepali case, there was widespread mobilization of labor unions in removing the king in 2006, however in 2007 the NED gave the ACILS $\$ 225,000$ for the Solidarity Center to “...support two of Nepal's largest democratic trade unions for voter education and get out the vote efforts..." (NED 2007). The larger (and so far unanswered) question is whether or not the ACILS was supporting 
and aligning with trade unions that supported American geostrategic aims at the exclusion of more popular labor organizations.

\section{IMPLICATIONS OF THE SOURCES OF SOLIDARITY CENTER FUNDING}

The preceding summary of the regional funding patterns of the American Center for International Labor Solidarity is instructive in highlighting the ongoing ties between the geostrategic objectives of the US state and the AFL-CIO's foreign policy activities after 1997. The relationship between the Solidarity Center and the NED is critical as an important indicator of continuities in the relationship of the Federation to U.S. foreign policy goals. The NED provides half of the operating budget for the ACILS, and the annual reports by the NED indicate significant patterns in the Solidarity Center-US state relationship. According to NED reports, ACILS often operates as a partner in regions of geostrategic importance for the U.S. state as it did during the Cold War.

In sum, two aspects of the relationship between the State-NED-ACILS stand out. First, there is a close correlation between areas of U.S. military activity and the operations of the Solidarity Center. For example, ACILS grants are funded in Iraq, Pakistan, and the states that make up the former Yugoslavia, at the same time that the U.S. engaged in military interventions and intelligence activity. Because of the paucity of data, it is unclear how far back in time the ACILS operations go in the Balkans. However there is a significant amount of spending in the region by the Solidarity Center that dries up shortly after the military campaign in the Balkans is wrapped up. The case of Iraq is most clear, as the Solidarity Center received massive grants from the NED immediately after the overthrow of the Hussein regime, which then petered out by 2008 . 
As Ronald Cox and I argued previously, "[i]t is hard to envision a scenario in which the Solidarity Center would prioritize these countries for labor organizing, if left to the opinions of the rank-and-file membership", which as indicated at the beginning of the chapter, indicates a pattern whereby the U.S. state is leading the ACILS (Cox 2012, 76).

Second, even in the absence of U.S. military intervention, the Solidarity Center still often acts in concert with dominant coalitions that are in-line with U.S. foreign policy goals. For example, the ACILS consistently receives large grants from the NED for regions where anti-neoliberal policies threaten the United States, such as Venezuela, Bolivia, and Haiti. The links between the Solidarity Center and the failed coup against Hugo Chavez illustrate that point in the extreme. However, the Solidarity Center has been actively involved in other countries of economic importance, for example the Eurasian region where significant amounts of oil and natural gas are located. In these examples, the ACILS is involved in "pipeline politics" that are tied into U.S. geostrategic goals of oil securitization.

\section{CHAPTER SUMMARY}

This chapter is an important "first cut" in examining whether or not the activities of the Solidarity Center can best be explained by the exigencies of the U.S. state, as was the case during the Cold War. Building on the background of Federation foreign policy during the Cold War, this chapter illuminates several key claims in understanding how the ACILS has operated since its inception. First, the politics behind the formation of the Solidarity Center were discussed. Second, the broad patterns of the relationship between the ACILS and the U.S. state via the National Endowment for Democracy were 
examined. And finally, I scrutinized the available records from the NED and the ACILS to illuminate the correlation between U.S. foreign policy shifts and Solidarity Center activity. In the course of doing so, several key points emerge.

First, beginning in the 1970s, numerous rank-and-file members began pushing for a full accounting of the past practices of the four foreign institutes. Over the following three decades, AFL-CIO officials routinely sidestepped these "clear the air" resolutions, and to date there has been no systematic evaluation of Federation foreign policy. This secretive policy, whereby foreign policy is insulated amongst a top-group of advisors including the IAD and IAC, continues until the present day and shows no signs of being opened for inspection or discussion. Therefore, investigating the linkages between U.S. foreign policy and the AFL-CIO involves significant deductive work, using the more rigorously accounted for NED annual reports and linking them to the vague and nonspecific Solidarity Center reports.

Second, the creation of the Solidarity Center was marked by optimism amongst scholars and labor activists who described the consolidation of the four regional institutes in hopeful terms. Moreover, this optimism based on several assumptions, including the fact that John Sweeney was an influential member of a group of labor leaders that opposed AIFLD policy in El Salvador and Central America during the 1980s, and that many of the "cold warriors" were removed from positions of power in the new ACILS. However, as discussed above, there are reasons to doubt that the creation of the ACILS was built upon a cathartic movement within labor, including the refusal of the AFL-CIO to "open the books", and the GAO memo sent to Senator David Pryor that indicate the "consolidation" was being urged by the Federation's benefactors. Taken together, the 
assumption that the Solidarity Center would represent a dramatic shift in foreign policy concerns is questionable.

Third, a broad examination of the funding relationships between the ACILS and the U.S. state indicate that nothing has changed in regard to the resource flows between the AFL-CIO foreign policy bodies and its patrons. In fact, it appears that if anything the Solidarity Center is slightly more dependent upon governmental and quasi-governmental organizations than ever before. During the period under review (2001-2009), the Solidarity Center received approximately $91-95 \%$ of all of its funding from government sources. The relationship between the Solidarity Center and government funding sources seriously calls into question the ACILS' own statements regarding its independence. Moreover, it makes clear that the recommendations by the AFL-CIO's own departments (including the International Affairs Committee) that the Solidarity Center be "weaned" off government funding has been completely ignored. Though the ACILS and AFL-CIO leadership may rightly claim that its members are taxpayers and thus have every right to these taxpayer dollars, this does not indicate that the Federation will be a meaningful counterweight to U.S. state policy. In fact, it indicates just the opposite: that the ACILS will continue to be, as the four foreign institutes were, a junior partner in implementing aspects of American foreign policy abroad.

Finally, and most critically, I detailed the patterns of funding from the NED to the ACILS from 2001-2009, indicating that Solidarity Center activity largely followed U.S. foreign policy, at least in broad terms, by receiving grants for areas of specific geostrategic concern. During this period, the ACILS saw spikes in funding for regions that saw military interventions by the United States, including the former Yugoslavia and 
Iraq, as well as countries that constituted part of the "war on terror" in the MENA region. In addition, the Solidarity Center received large grants for other regions of political concern for the United States, especially in areas where democratically elected officials pushed back against the neo-liberal program. Of particular concern, we saw significant activity in the Andean region, including Venezuela where the ACILS has been implicated in the temporary coup of Hugo Chavez in 2002. Finally, the Solidarity Center also received significant funding in the Eurasian region at the same time the U.S. state became more involved in a strategy of oil securitization.

Taken together, the data indicate that assertions that the ACILS has significantly shifted its policies in regard to where it operates, where it receives funding, and its independence from U.S. foreign policy are largely in question. From the broad strokes painted in the preceding pages, it is clear that the foreign policy of the AFL-CIO may still well be best explained by its relationship with the U.S. state. Therefore, the following chapter moves from the general to the particular by examining the details of AFL-CIO foreign policy via the Solidarity Center in specific countries of geopolitical interest. In short, chapter four looks to place ACILS activity into a similar typology to chapter two. That is, whether or not the on-the-ground activities of the ACILS fall into categories of stabilization and destabilization as they did during the Cold War. This in turn will answer the larger research question of whether AFL-CIO foreign policy in the Solidarity Center era is still best explained by its relationship with the U.S. state. It is to this question we now turn. 


\section{CHAPTER IV.}

\section{INTRODUCTION}

Some scholars and labor activists expressed optimism that the creation of the American Center for International Labor Solidarity would allow the AFL-CIO to chart a course that was more independent of the US state in foreign policymaking. However, as the record illustrates, the activities of the ACILS have demonstrated a strong continuity with past AFL-CIO foreign policy.

The reasons behind this continuity are multifaceted. First, the Federation itself refused to answer for past practices, routinely sabotaging motions to "clear the air" regarding foreign policy during the Cold War. Second, a previously unnoticed document from the General Accounting Office (GAO) to Senator David Pryor in 1996, indicates that the impetus for the creation of the Solidarity Center was not a desire to repudiate Cold War policies, but rather to "...change the programs to reflect post-Cold War political conditions" as demanded by USAID, a principal sponsor and benefactor of AFLCIO funding (GAO 1996, 2). Third, as my research indicates, the Solidarity Center ignored recommendations by the AFL-CIO's own International Affairs Department (now disbanded) that the ACILS be "weaned off" government funding in order to increase its independence from the U.S. state. Fourth, in fact, rather than decreasing its reliance on

funds from the U.S. government, the ACILS greatly increased its funding from the National Endowment for Democracy (NED), an important foreign policy arm of the U.S. state that uses less overt means to influence outcomes in foreign regimes. The NED has been the vehicle that transformed American Cold War interventionism into a more 
nuanced interventionism through "democracy promotion". As discussed in chapter two, "democracy promotion" involves a more subtle process of creating "limited democracies" whereby dominant elites contest for electoral success under a framework that institutionalizes neoliberal economic doctrine.

Finally, and most critically, by examining patterns of funding flows provided by the NED to the Solidarity Center from 2001-2009, a clear configuration emerges that demonstrate funding spikes in areas of U.S. geostrategic concern. The financial data indicates that the ACILS received concomitant jumps in funding allocations from the NED in areas of U.S. military interventions (the Balkans, Iraq, and Haiti), regions where anti-neoliberal regimes have taken power (Venezuela, Bolivia), or areas where politicoeconomic interests dominate (such as the oil and natural gas rich Eurasian region). This chapter complements the aggregate data explored thus far with an examination of three case studies where the ACILS activities tracked the priorities of the US state. The cases chosen reveal similar patterns of ACILS political activity, despite the varied histories and contexts of each of the countries and regions that will be examined.

First, I delve into the case of Venezuela, where scholars and activists have already uncovered significant ACILS linkages with labor organizations and anti-Chavez business elites that were involved in the brief coup in 2002. This section begins with a discussion of the role of the Venezuelan "pacted" democracy that gave the U.S. state a "stable" partner in the region from 1958-1998. This research indicates that the ACILS was an active recipient of a huge spike in "democracy promotion" funding from the NED, along with other core grantees, as part of a larger project by the U.S. state to reinvigorate the 
"limited democracy" of the Punto Fijo period in the face of an emerging popular democratic movement.

Next, I turn my attention to Haiti, and examine the relationship between the AFL$\mathrm{CIO}$ and democracy promotion activities in Haiti during the last 30 years. Whereas Venezuela demonstrates the response of the NED to a "limited democracy" under siege, the case of Haiti is much more complex and has involved a lengthy project by the U.S. state to create a stable set of polyarchic institutions over several decades. This section begins with an overview of the role of the precursor to the ACILS in Haiti, and then moves into a discussion of the 2004 coup that removed the popularly elected president from power again. In contrast to what occurred in Venezuela, the case of Haiti is largely defined by the absence of ACILS support for popular and established labor organizations, and instead by the controversial support for the radical labor organization Batay Ouvriye. This relationship raises interesting questions, as Batay Ouvriye seemingly shatters the idea that the ACILS only works with moderate and conservative "business union" oriented labor organizations. However, inferences can be gleaned that this was possibly a strategic move by the Solidarity Center and the NED to split leftist labor organizations that would have opposed the occupation and to bolster the credibility of right-wing organizations funded by other NED core-grantees.

In the final case study I move to a larger overview of ACILS activities in the MENA region following on the heels of the U.S. led "war on terror". Besides highlighting the tremendous shift in Solidarity Center priorities toward the Middle East and North Africa that correlate neatly with the Bush administration's plans to "democratize" the Middle East, this section examines some other particulars that 
exemplify the relationship between the ACILS and the U.S. state. Primarily this is investigated by examining the disconnect between the AFL-CIO domestically and the activities of the Solidarity Center in Iraq. While the Federation is demanding an end to the occupation at home, it is accepting increasingly large grants to work in occupied Iraq. This juxtaposition further supports the theory that far from being "independent" of the U.S. state and a "private" organization, the ACILS follows the lead of the U.S. state even when it is at direct odds with the Federation's rank and file. Finally, this case study briefly raises questions regarding the role of the Solidarity Center in the MENA states that compose the "Arab Spring” uprisings, particularly Egypt.

Each case will be examined in a systematic way. I begin by detailing the policies of the U.S. state in regard to each case study. That is, what the American government was trying to achieve in the state (or region) in question. Next, I highlight the funding patterns for the ACILS during this same time period, and then link them into the details of Solidarity Center activities where available to determine if the Federation was acting independently of the U.S. state, or as a supportive force in U.S. foreign policy as was the case during the Cold War. Critically, these case studies cover a dissimilar group of states and regions in order to examine to the fullest extent possible whether the Solidarity Center era is best marked by change or continuity in regard to following the lead of the U.S. state.

\section{VENEZUELA}

The case of Venezuela is of critical importance to this study, as it has been discussed quite a bit by labor scholars and activists. For some, the rough contours of 
what occurred in Venezuela in 2002 were similar to past AIFLD activity, especially in Chile in 1973 (see Golinger 2007, Scipes 2010, Moody 2007). In fact, numerous scholars have referred to the events in Venezuela as an important case study for helping to determine whether or not the activities of the Solidarity Center are indicative of a new direction for AFL-CIO foreign policy.

The brief April 2002 coup that temporarily removed the democratically elected President of Venezuela, Hugo Chavez and replaced him with the head of the Venezuela's largest business organization drew the condemnation of much of the globe, with the notable exception of the United States. Almost immediately after the short-lived coup, troubling reports indicated that the Solidarity Center had been involved with at least a segment of the coup leadership, including funding the Confederation of Venezuelan Workers (CTV), a labor organization that formed a vital part of the anti-Chavez demonstrations leading up to the coup (Marquis 2002). However, before delving into the details of what the ACILS was doing in Venezuela, it is first instructive to put the relationship between Venezuela and the United States into perspective.

Venezuela is an interesting case study for this work as it provides a prominent example of the theory of "democracy promotion", outlined in chapter two, as it pertains to U.S. foreign policy beginning in the early 1980s. Further, the Venezuelan case in many ways exemplifies William I. Robinson's theory of "polyarchy" discussed in the same chapter. While much of Latin America experienced a transition from authoritarian rule to polyarchic conditions beginning in the 1980s under the so-called "third wave" transitions, Venezuela proceeded in the opposite manner. Long considered one of the most "stable" democracies in Latin America, Venezuelan politics mirrored the "limited 
democracy" program for four decades before the election of Hugo Chavez in 1998, a fact

noted by many scholars including William Aviles and William I. Robinson (Cox 2012;

Robinson 2006).

Therefore, after a century of authoritarian and military regimes, Venezuelan politics entered into a period of electoral democracy in 1958, made possible by the combination of a political pact among elites and massive petroleum reserves (Norden 1998, 147; Aviles 2012, 150). This "pacted" democracy was formulated by dominant political players who reached a compromise (benefiting Venezuelan political and economic elites) that would lead to a stable democratic system for decades to come. As Aviles notes:

The Punto Fijo pact divided power between the major political parties, Democratic Action party (AD), the Christian Democratic Party (COPEI), and the Republican Democratic Union (URD). The pact was supported by military and business elites. The military was relatively unified behind leaving office after a decade in which the corruption scandals and brutality of the Perez-Jimenez regime had weakened the legitimacy and image of its institution. The three major parties agreed to coalition governments and a minimum program of economic policies which included support for import-substitution-industrialization and a large role for the state in the economy. The centrality of oil production to development accelerated urbanization and undermined the strength of a rural oligarchy that found its economic influence usurped by the state (Karl 1987) (as cited by Aviles $2012,150-1)$

Besides receiving support from both the business sector as well as the military, the pact also set the "rule of the game", defining the boundaries of the political sphere. In short, this meant that the Punto Fijo pact would operate under conditions which could be termed "polyarchic" according to William I. Robinson's definition; where elections 
would be tightly managed contests between the dominant political elites in the form of the three major parties. This arrangement, as Norden argues, meant that:

Competition and some uncertainty would be permitted, but not enough to threaten any major players. In the Pacta de Punto Fijo, party leaders agreed to curb mutual attacks, cooperate, and respect electoral outcomes, regardless of the winner. At the same time, the Programa Minimo de Gobierno committed the parties to a moderately progressive social agenda (Norden 1998, 147).

During the following two decades, Venezuela's democracy became more consolidated, leading to a situation where "... by the 1970 s, the political arena was dominated by two party organizations that were all but undistinguishable in their programmatic stances and relatively undifferentiated in their social make-up...” (Roberts 2008, 48). Critically, during the Punto Fijo period, Venezuela and the United States maintained close relations based on Venezuelan petroleum as well as significant military ties. During this time period, Venezuela generally supported the key pillar of U.S. foreign policy during the Cold War: anti-communism, especially as Venezuela combatted its own leftist guerrilla groups into the 1970s. (Aviles, 2012).

The Punto Fijo pact would dominate Venezuelan politics from 1958 until 1998, and at least for the first two decades, petro dollars were able to sustain modest development as well as fund security forces able to contain any popular uprising. However, in the 1980s a combination of a drop in oil prices, interest rate hikes, and increasing foreign debt led to an economic crisis. The response by political elites was to shift away from the import-substitution-industrialization strategy of the preceding years and to move in a neoliberal direction (Ibid.). Therefore, successive Venezuelan presidents moved to privatize key industries, including telecommunications, steel, and 
ports. Moreover, "[r]estrictions were also lifted on foreign investments and tariffs were dramatically lowered. The Caldera administration advanced the steady involvement of the private sector in exploring unexploited oil fields, limiting the state's involvement in these investments from 1 to 35 percent" (Ellner 2008, 90) (as cited by Aviles 2012, 152).

These policies were clearly in line with U.S. foreign policy objectives in advancing a neoliberal agenda in conjunction with IMF loan conditionality. However, as William Robinson makes clear in describing Latin America's experimentation with neoliberalism in the 1980s and 90s:

Neoliberalism, however, increasingly exhibits deep structural and social contradictions. In particular, the model is highly dependent on attracting mobile and often volatile transnational finance/investment capital, with a high component of financial speculation. Second, the new export boom, based on a set of non-traditional activities involved in regional participation in global production and distribution chains, is fragile as a consequence of global market competition, overproduction, and the impermanent nature of production sequences in the global economy while also accelerating ecological disaster. Third, the development model based on neoliberal integration into the global economy does not require (or is at least unable to couple the new accumulation potential with) domestic market expansion or an inclusionary social base. Fourth, as a result, the social contradictions generated by neoliberalism have led to heightened conflict, popular class mobilization, and political instability (Robinson 2007, 3)

In the case of Venezuela, this popular mobilization and increased conflict surfaced in the 1989 Caracazo, where rioting over the end of fuel subsidies and price controls for basic goods led to the deaths of hundreds of protestors (Aviles 2012, 152). However, it also set the stage for the entrance of Hugo Chavez and the Bolivarian Revolutionary Movement (MBR). Made up of army officers, and frustrated by what was seen as corrupt political parties and growing inequality in Venezuelan society, the Bolivarian movement had been formed in the early 1980s. Under the pretext of opposition to neoliberal restructuring and 
state repression during the Caracazo, the MBR attempted to overthrow the civilian government in 1992. The coup attempt failed and the leadership of the MBR was imprisoned, however it is important to note that the U.S. strongly condemned the coup attempt and in no uncertain terms urged all groups to limit their political aspirations to the ballot box (Ibid.). As will be demonstrated below, such a condemnation would not be repeated in 2002.

After being released from confinement, the MBR leadership regrouped as a political party, formed links with elements of civil society, and capitalized on growing discontent with the domination of what were increasingly seen as corrupt political parties. Six years after the MBR failed to overthrow the civilian order through extra-legal means, Hugo Chavez was elected president with an overwhelming majority by Venezuelan electoral standards. Upon taking office, Chavez and his supporters re-wrote the constitution to include greater public welfare protections and, most importantly, banned the privatization of the state-owned oil company PDSVA. In addition, the Chavez regime began implementing a series of anti-neoliberal reforms including raising royalties on foreign oil companies investing in Venezuela and significant land reform (Aviles 2012, 153).

Finally, Chavez began to use his position to become a vocal critic of American foreign policy; he challenged the U.S. over its "war on terror", refused to allow American anti-narcotic flights over Venezuelan territory, met with Iraqi dictator Saddam Hussein, and forged strong ties with Cuba (Clement 2005, 65). In short, while Venezuelan policies under the "pacted-democracy" era fit nicely with U.S. geostrategic aims, the political strategies pursued by the Chavez government after 1998 could not have been 
more at odds with Washington's priorities. First, the shifts in economic policy under Chavez were antithetical to the "Washington Consensus" economic formula that the U.S. state and the IMF have been championing in the developing world for the last 25 years. Second, Hugo Chavez became a vocal challenger of American foreign policy during the run-up to the "war on terror" and became a leader in challenging American political power in what had been a mostly quiet Latin America in the previous decade. The end result of this combination of policies and rhetoric put the Chavez regime in conflict with U.S. strategic goals in the region and the world.

Thus, as mentioned previously, in many ways Venezuela in the Chavez era has transitioned from a limited-democracy or polyarchy to a populist, left-led political system through democratic and open elections. Although questions regarding power centralization under the Chavez regime may be legitimate, there is scant evidence to suggest that Venezuela is less democratic now than during the "pacted democracy" era or that Hugo Chavez is an illegitimate president. In fact, as William I. Robinson pointed out, discussing several significant facts about the rise of Chavismo:

...the Venezuelan revolution had impeccable bourgeois democratic legitimacy. Chávez won the 1998 presidential elections by the largest majority in four decades (56.2 per cent) and then went on, between 1999 and 2006, to ratify his democratic legitimacy in another eight electoral contests, including three further presidential votes (in 2000, with 59 per cent of the vote, in 2004 with 59 per cent, and in 2006, with 63 per cent), a constitutional referendum, and several parliamentary, gubernatorial and local elections (Robinson 2007, 9).

In other words, for all of the complaints that the United States might have lodged against the rhetoric of Hugo Chavez, or the anti-neoliberal agenda Venezuela began to pursue, 
there was no doubt that Chavez electoral victories had expressed the will of the majority of the citizenry.

Critically, as numerous scholars have documented, it was at this precise juncture when the NED (through its core grantees including the ACILS) began a large scale funding increase for "democracy promotion" programs in Venezuela (Golinger 2007; Clement 2005). This was not the first time that NED funds were designated for Venezuela. As Tim Shorrock noted, the pre-cursor to the Solidarity Center (AIFLD) had a relationship with the CTV dating back to the 1970s “... when Venezuelan unions, through their alliances with the Democratic Action Party, were for many years part of the center-right government" (Shorrock 2003, 8). According to Shorrock "[t]he archives show that the AFL-CIO and the CTV worked closely in those years to isolate Cuba and counter the influence of left-wing unions in Latin America" as well as being a conduit for bilateral discussions regarding oil (Ibid.). As will be discussed in the final case study on Iraq, Egypt, and the MENA region, this fits into the pattern of democracy promotion strategies that take shape in the 1980s which often involves creating and using organizations ostensibly "based" in a neighboring state to implement policies dictated by the U.S. state. For example, in Venezuela, the CTV also worked with AIFLD during the 1980s in an effort to recruit workers in Nicaragua into the Contras (Golinger 2004, 9).

The alliance between the CTV and the AD party is another aspect of the narrative that is critical to place in context. Throughout the Punto Fijo era, the CTV was looselyaligned with the AD party, although they did allow for other (minor) political currents to be represented (Ellner 2009). Moreover, during this time period the CTV often partnered with the Venezuelan state in implementing policy. For example, during the financial 
crisis of the 1980s, the CTV routinely accepted privatization, wage and benefit cuts in line with neoliberal reforms, and even helped draft some of these measures $(2008,117)$. This is important as, during the 1998 campaign, Chavez "embraced a fervently antiparty discourse at the same time that he attacked the established labor leadership as a 'tradeunion mafia' that slavishly defended the positions of AD and COPEI" $(2005,54)$. As Ellner notes, this put the CTV leadership into a defensive position even before Chavez assumed the presidency. Upon taking office, the Chavista movement was divided by what course to chart in regard to organized labor, with some pushing for parallel unionism and others pushing for the destruction of the CTV (54-55). Without straying too far off course, this conflict would lead to several contested union elections and eventually push the leadership of the CTV into an unlikely alliance with FEDECAMARAS, the powerful Venezuelan business association that also placed itself in vehement opposition to the Chavez government. What is important for this work is that the anti-party and anti-neoliberal rhetoric of Chavez set off warning bells both in Washington and within powerful circles in Venezuela.

The tensions between Washington and Caracas would increase significantly between the election of Hugo Chavez to the presidency in 1998 and the brief coup in 2002. By that time, U.S. officials had begun to question Chavez's legitimacy and commitment to democracy (Clement 2005, 67-9). However, though the diplomatic relationship in the public eye degenerated over time, in actuality the "democracy promotion" program was clearly put into full effect immediately following the 1998 election. Although not discussed in detail in chapter three (since the Solidarity Center does not have published reports of spending prior to 2001) the NED funding data for the 
ACILS is available for the years prior to 2001. Looking at NED funding to the ACILS in these years gives us a baseline that indicates a startling trend. This pattern has been examined by several other authors, including Christopher Clement who notes "NED spending in Venezuela during the period illustrates that the organization responded to Chavismo almost from the start. In 1999, Venezuela ranked the highest of 11 countries in the region for NED-funded programs" (66).

This makes sense if one considers the NED's own 1999 annual report, which described the "situation" in Venezuela in alarmist terms:

In recent years, the optimism that accompanied the initial wave of elections in Latin America has faded to concern about the region's "imperiled democratic progress." While countries such as Argentina, Guatemala, and Panama celebrated watershed elections this year, events in Colombia, Peru, Ecuador and Venezuela have raised serious questions about the stability and quality of democracy in the region... In Venezuela the election of ex-Lt. Colonel Hugo Chavez demonstrated the depth of voters' anger against ineffective government and corruption and has sent shockwaves throughout the region. It is still uncertain what the long-term effects of President Hugo Chavez's election and the hastily drafted constitution will be on Venezuelan democracy, but political brinkmanship and the actions by the constituent assembly that sharply limited the powers of the congress and judiciary have raised serious concerns about political polarization and the intention of the regime... (NED 1999).

In other words, immediately following an election in which a candidate won with the largest margin in four decades of Venezuelan democracy, the NED began describing Venezuelan democracy as being imperiled and hinting at the uncertainty of President Chavez's intentions. The NED was not responding to a "democracy" deficit in Venezuela. Rather, the position of the NED was a response to the expression of popular democracy and the threat it posed to both Venezuelan elites and U.S. hegemony. 
More to the point, as the evidence below indicates, the specific funding for the ACILS itself via the NED increased significantly upon the election of Hugo Chavez. In 1997, the ACILS received $\$ 72,250$ for work in Venezuela " $[\mathrm{t}] \mathrm{o}$ help the Confederation of Venezuelan Workers modernize its structure and bolster its financial base. ACILS also assists in developing policy recommendations regarding privatization and economic restructuring through seminars, training, and technical assistance” (NED 1997). In 1998, prior to the election of Hugo Chavez, the Solidarity Center received a single grant through the NED for $\$ 54,289$ with the intentions of "strengthening" the CTV's ability to “...assume a greater role in political and economic debates in Venezuela" (NED 1998).

However, in 1999, the same year the NED annual report expressed its "concern" over the election results, the ACILS received a Venezuela specific grant for $\$ 242,926$ to assist the CTV "conduct internal elections" and to "...promote widespread support and participation in the election process through a public education radio and newspaper education campaign..." (NED 1999). Along with the quarter million dollar Venezuelaspecific grant, the ACILS also received a grant for the Andean "region" for $\$ 79,433$ “[ $[\mathrm{t}] \mathrm{o}$ promote the political participation of unions..." (Ibid.). In other words, the Solidarity Center funding from the NED for its activities in Venezuela quintupled in the year after Hugo Chavez's electoral victory. And it wasn't just the ACILS that received a funding boost. As a further point of reference, in 1998 total NED funding for Venezuela through its four core grantees and other organizations amounted to $\$ 656,334$ (NED 1998). In 1999, this number jumped to $\$ 1,047,370$ for Venezuelan specific grants, a significant increase from the previous budget (NED 1999). Another of the core-grantees, the International Republican Institute (IRI) was also extremely active in Venezuela, linking 
with opposition groups and actively working to advise oppositional figures (Clement $2005,70)$.

The larger question thus becomes, what was the Solidarity Center doing with the NED funds as part of the democracy promotion network? In particular, what relationship, if any, exists between the spikes in ACILS funding via the NED and the destabilization campaign that led to the brief coup in April of 2002? On April 25, 2002, Christopher Marquis of The New York Times detailed how NED funding had "quadrupled" its Venezuela budget in the run up to the 48-hour coup on April $11^{\text {th }}$ of the same year. Specifically, Marquis (2002) wrote that:

Of particular concern is $\$ 154,377$ given by the endowment to the American Center for International Labor Solidarity, the international arm of the A.F.L.-C.I.O., to assist the main Venezuelan labor union in advancing labor rights. The Venezuelan union, the Confederation of Venezuelan Workers, led the work stoppages that galvanized the opposition to Mr. Chávez. The union's leader, Carlos Ortega, worked closely with Pedro Carmona Estanga, the businessman who briefly took over from Mr. Chávez, in challenging the government.

Since then, numerous scholars and journalists have attempted to link the ACILS and other NED connected NGOs to the April 11, 2002 coup that removed Hugo Chavez from power and installed the head of FEDECAMARAS in the presidency. However, there is no "smoking gun" that indicates the ACILS was involved in the coup itself, and crucially, for purposes of this work, there is no need to prove that the ACILS was so involved. Rather, my concern is whether the activities of the Solidarity Center can best be explained by its relationship with the U.S. state. In this regard, the Venezuela case study is most instructive. The evidence that the Solidarity Center followed the lead of the U.S. state in the "democracy promotion" program in Venezuela is fairly straightforward. 
First, the ACILS was clearly part and parcel of the NED funding explosion for Venezuela immediately following the election of Hugo Chavez in 1998. Although the NED often touts its independent status, as does the ACILS, the fact remains that the largest source of funds for the NED and its grantees is the U.S. state. The election of Hugo Chavez represented a dual annoyance for American foreign policy goals. The antineoliberal program pursued by the Chavez regime represented the first significant democratic challenge to the neoliberal orthodoxy that the IMF and the United States had been pushing in the region for several decades. Further, the Chavez regime opposed American foreign policy designs in its broader sense, refusing to allow anti-narcotics flights over Venezuelan airspace and meeting with foreign leaders deemed undesirable by U.S. policymakers. Therefore, it is no surprise that the U.S. state repeatedly expressed its displeasure with the Chavez regime and turned its attention to the NED for a "solution" to the Venezuelan problem.

This solution did not have to involve the plotting of a coup; however, it is clear that at the very least the "democracy promotion" agenda of the NED and its grantees involved bolstering political elites that had dominated during the Punto Fijo era. More to the point, in its own State Department report, the Office of the Inspector General denied that U.S. policymakers had directly offered assistance in removing or undermining the Chavez regime "... at least not through other than democratic and constitutional means. Of course, the various assistance programs discussed in the answer to Question five [concerning the role of the NED and affiliated organizations] were strengthening organizations opposed to President Chavez" (U.S. Department of State 2002, 19). The entire State Department report is very instructive as to U.S. policy towards the Chavez. 
While it repeats again and again that the U.S. supported only democratic change, the State Department admits:

It is clear, though, that neither the Department nor the embassy sought out Chávez supporters in or out of government in any aggressive, organized fashion. The opposition's willingness to talk to Embassy Caracas in detail about their plans against President Chávez and the embassy's willingness to listen may have left doubts about the sincerity of our professed opposition to undemocratic and unconstitutional means of removing President Chávez. We do not mean to suggest that the embassy should have avoided meeting with the opposition; but the frequency of such contacts, and the relative lack of contact with pro-Chávez elements, may have led some Venezuelans to question whether the United States was really neutral as regards Venezuelan internal politics. As noted above, in retrospect, this imbalance in outreach was acknowledged by U.S. officials to be a shortcoming, and we understand that steps have been taken subsequently to increase contacts with the Chávez government and its supporters in Venezuelan society (18).

This conceptual tool, what is often referred to as "plausible deniability", runs throughout the State Department report and as will be discussed in the conclusion, often forms the backbone of Solidarity Center claims as to its neutrality and independence. In this case, plausible deniability posited that the U.S. state and the NED were not directly involved in the coup, but were definitely involved in strengthening the opposition movement and "lamentably" perhaps not forceful enough in denouncing coup preparations by these same organizations. The State Department also makes it clear that none of this was “...inconsistent with U.S. law and policy", indicating that there is really nothing to these allegations other than some accidental missteps (21).

Second, the CTV is repeatedly identified in NED reports as the labor organization that the ACILS partnered with in Venezuela, as in decades past under AIFLD. The CTV was previously intimately linked to the AD party generally, and in particular was seen as a partner in the pacted democracy in Venezuela during the Punto Fijo era (See Ellner 
2008, 2009). Though Stan Gacek, then AFL-CIO Assistant Director of International Affairs for Latin America, would argue that the Solidarity Center “... have included nonCTV and pro-Chávez labor organizations in our programs since 1999" in his response to criticism of ACILS projects in Venezuela, no other specific information (names of these organizations or projects undertaken) have ever been disclosed (Gacek 2005, 113). The State Department review of ACILS activity via NED funds exclusively mentions the $\mathrm{CTV}$ as the sole recipient of grant monies and, most importantly, the AFL-CIO's own statement regarding the April coup explicitly states that it had been supporting the CTV in a process of internal democratization and that "[a]11 of the AFL-CIO-Solidarity Center's funding for Venezuela went for this purpose" (Shorrock 2002). Based upon this information there appears to be no evidence to support any assertion that the ACILS was involved with other labor organizations in Venezuela, regardless of statements made after the failure of the 2002 coup.

There is also evidence that the ACILS-CTV connection ran deeper than the Solidarity Center was willing to admit after the coup had fallen apart and journalists began questioning the Solidarity Center (and other NED grantees) programs in Venezuela. Katherine Hoyt describes a closed forum held in February, 2002 involving representatives of the CTV and NED that followed on the heels of a December strike/lockout by business owners and the CTV to protest the Chavez government (Hoyt 2002). Most importantly, Hoyt writes that " $[t]$ he invitation to the forum sent out by the AFL-CIO and NED proudly stated that the CTV played 'a key role in the national strike on December 10' and joined with business and other groups in "a massive demonstration against the government on January 23" (Ibid.). It was well known that the CTV 
leadership, specifically CTV Secretary-General Carlos Ortega, had aligned with the powerful business group FEDECAMARAS and led “...three general strikes/lockouts of December 2001, March-April 2002, and December 2002-February 2003" (Collier 2004, 94) (see also Ellner 2008, 115). Obviously, none of this indicates that the ACILS was in any way directly involved in the coup, but the Solidarity Center's claims that they were unaware of any activities outside of their "labor democratization" program seem to ring hollow when compared to this evidence. As mentioned above, the CTV leadership traveled to Washington D.C. to meet with AFL-CIO leadership as well as with Otto Reich, then Assistant Secretary of State for Western Hemisphere Affairs, shortly before the April, 2002 coup (Scipes 2006; Hoyt 2002; Golinger 2005). Such activities are inconsistent with an organization that supposedly was only concerned with internal democratization of the CTV.

Furthermore, by 2005 the ACILS was adamant that there was no reason for concern regarding its Venezuelan activities and eager to present their work as involving numerous labor organizations. However, the AFL-CIO statement released in the immediate aftermath of the 2002 coup reads more like a laundry list of justifications for Chavez's overthrow. After three brief sentences acknowledging the relationship between the CTV and the ACILS, the statement turns to the ways in which the Chavez government was in essence responsible for the coup:

From the moment he took office in 1999, Hugo Chávez led an assault on freedom of association, attempting to weaken or eliminate the principal institutions of Venezuelan civil society, including the unions. His methods included public calls for the "destruction" of the CTV, suspension of collective bargaining in the public sector and the petroleum industry by decree, threats to freeze union bank accounts, and formation of a parallel "Bolivarian Workers' Front." Chávez's attack on the CTV culminated in a 
December 2000 referendum on internal union governance in which all citizens- including non-union members such as business people and the military, could vote... It was these very attacks on freedom of association that led to a number of the collective actions and demonstrations that occurred this month. It was such attacks, along with the country's miserable economic performance ( $16 \%$ unemployment), that caused the CTV to join with Venezuela's business sector to put forward a ten-point plan for dialogue, with elimination of poverty as the first objective (Shorrock 2002).

Finally, the brief 2002 coup was initially supported by the U.S. state, which released similar statements blaming President Chavez for the unrest. Most telling is the press statement released on April 12, 2002 by the U.S. State Department, which read:

Yesterday's events in Venezuela resulted in a transitional government until new elections can be held. Though details are still unclear, undemocratic actions committed or encouraged by the Chavez administration provoked yesterday's crisis in Venezuela. According to the best information available, at this time: Yesterday, hundreds of thousands of Venezuelans gathered peacefully to seek redress of their grievances. The Chavez Government attempted to suppress peaceful demonstrations. Chavez supporters, on orders, fired on unarmed, peaceful protestors, resulting in more than 100 wounded or killed. Venezuelan military and police refused orders to fire on peaceful demonstrators and refused to support the government's role in such human rights violations. The government prevented five independent television stations from reporting on events. The results of these provocations are: Chavez resigned the presidency. Before resigning, he dismissed the Vice President and the Cabinet. A transition civilian government has promised early elections (U.S. Department of State 2002, 76).

Later, U.S. officials argued that they had been misled, and were expressing support not for a coup, but were under the impression that Hugo Chavez had resigned, a dubious proposition given the amount of information the U.S. had concerning the coup plans. Moreover, the State Department did not urge the coup leaders to stand down or channel 
their frustrations through constitutional channels (as the U.S. did during the attempted coup in 1992), but instead places the blame on the Chavez government.

Critically, diplomatic cables obtained by Eva Golinger through Freedom of Information Act requests indicate that far from being misled, the U.S. state had advance notice of the coup, explaining that these cables make clear "[i]f it had any doubts before, as of March 5, 2002, the US embassy must have been absolutely clear that the opposition was planning to get rid of Chavez" (Golinger 2006, 62). Golinger and Jeremy Bigwood also published other cables obtained through FOIA requests that indicate the CIA was well aware of the coup planning. Though the website that hosted these cables has since been taken down, numerous journalists reported these facts, which included a cable sent just five days before the coup which read “... disgruntled senior officers and a group of radical junior officers are stepping up efforts to organize a coup against President Chávez, possibly as early as this month" and that the strategy for the coup leaders was to "exploit unrest stemming from opposition demonstrations slated for later this month" (Forero 2004) (citing Golinger and Bigwood n/a). Forero also quotes another declassified cable just days after which explicitly read: “[d]isgruntled officers are planning a coup" (Forero 2004). Given that "[t]hese intelligence briefs are typically read by as many as 200 officials in the Bush administration" it seems highly unlikely that the administration did not know of the coup (Ibid.). Therefore, the Bush administration knew a coup was being planned and that the plan was likely to involve an incident of civil unrest instigated by the coup leaders to justify their actions. The statement after the coup appears calculated to provide plausible deniability to the idea that the U.S. supported or 
had advance knowledge of the coup and sheds serious doubt on claims by the United States that it believed Hugo Chavez had stepped down willingly.

Finally, the former Mexican Foreign minister, Jorge Castaneda revealed in an interview in 2004 that far from opposing the coup, the U.S. was busy working to cobble together international support for the Carmona regime: "[i]n effect there was a proposal from the US and Spain to release a declaration of recognition of the government of Pedro Carmona, including the support of Mexico, Brazil, Argentina and France" (Castaneda 2004). Again, though there is little direct evidence to support the thesis that the U.S. or NED was directly involved in the coup, it is clear that U.S. policymakers, if not supportive of a coup, were well aware that it was being developed and attempted to bolster support for the Carmona regime immediately following the removal of President Chavez from power.

Thus, though other scholars and activists (see Scipes, Golinger, Hirsch, etc.) have been looking for the "smoking gun" to prove that the ACILS was actively involved in plotting to remove President Chavez by extra-constitutional means, I argue that such a classification is nearly impossible to prove. Moreover, for this work it is unnecessary to attempt to confirm or deny that NED funded groups were so engaged. In regard to the central proposition of this work, it is clear that the ACILS activity in Venezuela was largely a product of the U.S. state, if not simply because of the sudden and drastic shift in funding flows, then by the choice of partnering with the CTV at the exclusion of other labor organizations even after the CTV leadership had clearly aligned with FEDECAMARAS and engaged in strikes and lockouts aimed at destabilizing the Chavez regime. 
Given the alliances developing between the CTV, FEDECAMARAS and other opposition groups and declassified documents regarding the likelihood of a coup, it seems unlikely that the ACILS was caught completely by surprise or had no knowledge of the intentions of the CTV. As will be discussed in depth in the conclusion, the ACILS has routinely engaged in a pattern of "plausible deniability" in regard to the destabilization campaign in Venezuela. That is, the statements released by the Solidarity Center regarding activities in Venezuela has always centered exclusively on whether or not ACILS staff were part of the coup plot rather than whether their actions contributed to the larger destabilization campaign. These accusations are in fact "plausibly deniable" and therefore the ACILS sees little need to elaborate further than brief denials of conspiracy.

In reading these statements, for example Stan Gacek's two editorials in the New Labor Forum, the emphasis has always avoided the larger question posed by scholars and activists: why the ACILS was involved in taking such large sums of money at such an opportune time from the U.S. state via the NED for work with organizations that eventually (and unsurprisingly) engaged in extra-legal maneuvers. While scholars discuss the intricate details of ACILS work in Venezuela, Gacek and others continue to insist that any suggestions of complicity are beyond the pale, without ever addressing the larger questions of why the ACILS was so suddenly concerned with the CTV in particular, and the labor situation generally, in Venezuela from 1998-2002.

Therefore, in regard to the ACILS activities in Venezuela, I argue that the degree of complicity between the Solidarity Center and the coup plotters is irrelevant to my own research. The ACILS was clearly one of the largest recipients of NED funding that by 
the State Departments own admission was designed for “...strengthening organizations opposed to President Chavez" (U.S. Department of State 2002, 19). In the following sections regarding Haiti and Iraq it will become clear that while the ACILS has largely relied on the convenient "plausible deniability" cover, it does not protect the Solidarity Center for the larger indications that its activities abroad are largely shaped by the exigencies of the U.S. state. Again and again, the foreign arm of the AFL-CIO finds itself embroiled in controversy following on the heels of U.S.-led and NED-granted controversy. It is to these other two cases we now turn.

\section{HAITI: "STOP AND GO DEMOCRACY-BUILDING"}

Under the auspices of building democracy, the U.S. government is trying to organize, finance, and equip sectors of Haitian society that oppose the government of Jean-Bertrand Aristide... funneling money to Haitian organizations that constituted a different, much smaller sector of civil society, one with a conservative political perspective. Trade unions, political parties, broadcast and print media, civic associations, and educational organizations were funded to promote a conservative form of electoral democracy. The "pro-democracy" funding has been channeled primarily through NED and the Agency for International Development (AID)... (Sims 1992, 1).

Beth Sims' description of "democracy promotion" activities in Haiti identifies the central concerns of U.S. policymakers towards the impoverished Caribbean nation since the ousting of Dictator Jean-Claude "Baby Doc" Duvalier in 1986. Tellingly, Sims' analysis was written not in 2004, when similar "democracy promotion" activities were under way, but over two decades ago, when the NED and its core grantees helped organize a destabilization campaign against the popularly elected government of Jean Bertrand Aristide. That effort culminated in a military coup, which removed him from the 
presidency after just seven months in office. This pattern of "stop and go democracybuilding" as Sims termed it, which began in the mid-1980s was still the backbone of U.S. foreign policy to Haiti in 2004, when President Aristide was removed again from power after a massive amount of "democracy promoting" funding flooded into Haiti.

Therefore, while the Venezuelan case discussed above indicated the degree to which the "democracy promotion" activities spiked after the breakdown of the polyarchic order in 1998, the Haitian case presents a much more complex case study as the role of the NED and AID stretches back over several decades. Interestingly, the parallels between the two cases indicate the degree to which "democracy promotion" programs have remained constant over time. Before moving into a discussion of the ACILS activities surrounding the 2004 coup and its aftermath, it is important to discuss the historical context of "democracy promotion" and polyarchy, and the relationship between U.S. and AFL-CIO foreign policy in Haiti over the last 30 years.

The relationship between Haiti and the United States has been one of constant intervention, with the first large-scale invasion and occupation by the U.S. occurring in 1915 under the pretext of civilizing and democratizing Haiti (Schmidt 1995, 6). This early form of democracy promotion ran counter to statements by President Wilson that the U.S. would treat Latin American nations with "equality and honor" and had much more to do with "teaching" Haiti to "elect good men" (9). During the occupation the U.S. installed a client regime, disbanded the National Assembly in order to rewrite laws to allow for foreign ownership, and attempted to impose "...American concepts of political morality, pragmatism and efficiency" on Haitian society (135). 
Moving quickly ahead, in between the end of direct U.S. rule and 1957, the Haitian political system was wracked by political chaos, leading to the dictatorship of Francois "Papa Doc" Duvalier who, with the backing of the U.S. “... achieved stable, although not consensual domination" of Haiti and became a reliable despot for the United States, along with his son "Baby Doc", for the next three decades (Robinson 1996, 268). As William I. Robinson explained in his case study of Haiti and polyarchy, “...Duvalierism was sustained by naked repression and a triple - if always tensionriddled - alliance between Duvalierist cronies, the Haitian elite, and the United States" (269). In the 1970s, AID identified Haiti as a possible location for free-trade zones and low wage manufacturing, a process which would be moved forward with the Caribbean Basin Initiative in 1981 under President Reagan and supported by AIFLD (Sims 1992, 26). By the mid-1980s the arrangement that allowed Duvalieriests to dominate the political and economic spheres while the majority languished in intense poverty became problematic. As Robinson makes clear, the U.S. transition from support for dictatorships to "limited" democracies is the result of these contradictions and the realization that tightly managed democracies can both safeguard global capitalism while channeling popular discontent into established juridical and political institutions. In short, the transition to polyarchy (and the attendant push by the U.S. state via the NED and AID for "democracy promotion") is one of necessity and pragmatism as opposed to concerns of "human rights" and "democracy" that are the buzzwords accompanying such shifts.

In February, 1986, Baby Doc Duvalier was finally forced to flee in exile to France by a popular uprising. The next five years were chaotic, and marked by violence and the absence of effective governance (Robinson 1996, 276). As Sims and Robinson note, it 
was only after the end of the dictatorship that the United States became interested in promoting democracy and the attendant concepts of "human rights" etc.

Washington's interest in Haiti after Duvalier's ouster was piqued by the wish to guide the country's post-Duvalier transition away from potentially radical options. Reflecting that concern, NED's grants to Haitian organizations in 1986 totaled $\$ 400,881$, the highest total for any year until the 1990 elections. From 1986 to 1990, NED funneled \$2.3 million to grantees in Haiti. More than $50 \%$ of that total was granted in 1990, mostly for election activities (Sims 1992, 1).

Initially, elections were planned for November, 1987, however these were canceled and “[b]etween 1987 and 1990, three coups took place and another scheduled election was canceled” (Robinson 1996, 281). During this time “...most of NED’s grants supported just three Haitian institutions, the Haitian International Institute for Research and Development (IHRED), and two conservative union organizations, the Federation of Trade Union Workers (FOS) and the General Organization of Haitian Workers (OGITH)" (Sims 1992, 1). Ostensibly, the activity by these groups inside Haiti was to help support Haitian democracy. However, as Robinson and Sims make clear, the actual intent was to funnel funds to organizations that were malleable and amenable to U.S. interests. During the period between the fall of the Duvalier regime and the first open election in Haitian history, Jean Bertrand Aristide and his Lavalas ("Flood") movement became increasingly influential among poor and working class Haitians.

Aristide, a priest removed from the church due his support for liberation theology, was easily the favorite to lead the post-Duvalier Haiti, and his Lavalas movement created a loosely bound but powerful actor during the transition. As Robinson notes, "[o]ne would have expected any outside power truly interested in promoting democracy in Haiti to have given technical or organizational support to this highly representative force...", 
yet the funding by AID and the NED instead focused on identifying professionals and elites in order to cultivate a group of leadership worthy technocrats and ignored, if not scorned Aristide (Robinson, 1996, 284-285). In terms of the labor movement, this meant significant funding for the FOS, while for other organizations the funding was aimed at conservative elites, many with ties to the previous regime.

As mentioned above, understanding the NED and AIFLD's support of the FOS in particular is critical, as the FOS received the majority of NED grants directed at labor during the pre and post-transition period. Far from being a radical organization demanding "democracy" and an end to Duvalier's rule (what would seem to be the requisite characteristics for "democracy building" funds), the FOS was initially created with the consent of Duvalier, who needed a moderate union to meet the labor requirements of the CBI. Therefore, the FOS can be seen as a parallel union, created at the behest of the of the U.S. state with the blessing of the Haitian dictator in order to undermine labor movements which questioned not only the benefits of the CBI, but the rule of Duvalier himself.

In 1986, after decades of U.S. support for the regime of Baby Doc and his father, the U.S. State Department again sought out AIFLD as a partner in furthering U.S. foreign policy goals. This runs counter to the narrative promoted by AIFLD at the time (and the Solidarity Center today): that it was an independent organization which asked for and received funding for operations of its choosing with no strings attached. Regardless, in line with the "democracy promotion" program, AIFLD was asked to increase its activities with the FOS. As Sims notes: 
According to a June 1986 White House briefing for U.S. chief executive officers of major corporations, the State Department requested AIFLD's involvement "because of the presence of radical labor unions and the high risk that other unions may become radicalized." At the time of this jump in U.S. financing, FOS was dominated by the Chauffeur Guide, the taxi drivers' union run under Duvalier by the security police and infiltrated by the Tontons Macoutes $(1992,3)$.

The unions that worried the United States, and Duvalier before he was removed from power, were organizations that connected urban and rural opposition groups like the “...Autonomous Federation of Haitian Workers (CATH), which had sprung up in the 1970s among workers in the industrial-free trade zone, led by the veteran trade unionist and anti-Duvalier militant Yves Richards” which “...practiced an activist and community-based trade unionism, bringing together some forty workers' unions with some two dozen urban neighborhood committee federations and twelve peasant associations" (Robinson 1996, 283). In other words, broad-based and popular labor organizations which opposed the dictatorship were considered too radical for the U.S. state and AIFLD. Instead, AIFLD s primary partner in Haiti was its own creation, the FOS, with a much smaller membership base and a moderate, pro-business platform. More to the point, it seems that the primary motivation was to counter the power of the Lavalas-aligned CATH (289). Thus, “[w]hen CATH workers organized and led strikes, for example, they would be fired or otherwise harassed, while FOS — promoting the probusiness union philosophy backed by AIFLD—would be accepted by management" (Sims 1992, 3).

Therefore, in the run-up to the 1990 elections, the vast majority of funding for "democracy promotion" in Haiti was funneled directly to organizations that supported an 
agenda compatible with U.S. foreign policy goals rather than groups that were either fundamentally popular (Lavalas), or who had an established track-record of fighting against the Duvalier dictatorship, such as the CATH (although Sims notes that early in 1990, CATH was taken over by a conservative wing of the social democrats and began to support the U.S.-backed candidate and therefore began to receive U.S. support) (Ibid.). This pattern of ignoring the basic relationship between popular organizations and democracy is even more pronounced when one considers that the core grantees of the NED funded approximately 16 different political parties running candidates for office in 1990, with “...none of them from the Lavalas movement” (Robinson 1996, 287). This is a striking paradox which indicates that the United States was not interested in popular democracy in Haiti, as U.S. political elites were more than aware of the overwhelming popularity of Aristide and Lavalas, but rather was interested in developing a "limited democracy" which would benefit plans to re-organize the Haitian economy in line with U.S. business interests (Metayer 2012).

The 1990 Haitian elections stand out as a prime example of the theory of "democracy promotion" and the relationship between the theory and the organizations that further it on the ground. Further, the similarities between Haiti in 1990-91, and Venezuela during 1998-2002 (and by some accounts, up until the current day) are instructive in many regards. When the ballots were counted in 1990, the election was nothing short of a landslide for Aristide, who took nearly $70 \%$ of the votes for president in an election deemed free and fair by international observers. This electoral outcome is all the more impressive considering that Aristide and the Lavalas supported National Front for Democratic Convergence (FNDC) coalition received no outside support from 
"democracy promotion" organizations like the NED (Ibid.). Therefore, much like Hugo Chavez in 1998, who won with the largest margin of victory in four decades in Venezuela, the Aristide victory in Haiti seemed to indicate that democracy, in the form of the will of the citizenry being reflected in electoral outcomes, was flourishing.

Unfortunately for Haiti, as discussed previously, popular democracy is not what the U.S. state and its "democracy promotion" apparatus had in mind.

Almost immediately after Aristide's landslide victory, opposition began to form from outside quarters. In a manner that is eerily similar to the warning bells tolled by the NED with the election of Hugo Chavez in 1998, Beth Sims noted that:

The Free Trade Union Institute (FTUI), NED's core grantee for labor, spoke positively about Haiti's first free, fair elections. But FTUI's view of the president-elect was immediately critical. 'As 1991 opened,' FTUI told NED in its fourth quarter report for 1990, 'Aristide prepared to usher in his new order, a rhetorically extreme program that seemed to be deliberately framed to strain relationships with many of Haiti's democratic friends' $(1992,4)$.

Partly this opposition may have stemmed from the fact that the NED and its grantees had invested so heavily in candidates and organizations which were roundly rejected by the citizenry. The National Democratic Institute (NDI), another core-grantee of the NED, published its "Final Report" on the elections and casually mentions that when Aristide was asked if he would accept the results of the election if he lost, he "...insisted that he would win, and if he didn't, it followed that the elections were rigged" (National Democratic Institute of International Affairs 1991, 25). In contrast, the report also mentions that the "runner-up" (and also the most heavily backed candidate by the NED and U.S.) Marc Bazin “... accepted his defeat gracefully...” (27). 
If the subtle signals were a warning, the activities of the U.S. state, and the NED and its grantees immediately following Aristide's overwhelming victory were a definitive statement. Just as in Venezuela in 1998, a strong democratic victory by an outside candidate was not seen as an indication of democratic success. Thus:

Following Aristide's election, U.S. funding for political activities in Haiti increased dramatically. In May 1991 Congress authorized AID to spend \$24.4 million under the Democracy Enhancement Project. The four-year grant was to "strengthen legislative and other constitutional structures ... local governments, [and] independent organizations," such as labor unions, political parties, the media, professional groups, civic associations, and women's and youth groups. AID documents show that Washington was poised to take advantage of a "window of opportunity" to "effect meaningful change in the Haitian social and political context." The goal, according to AID, was "not simply more individuals who know about democracy, but rather an increase in the number and type of institutions that can channel constructive competition into pluralistic endeavors" (Sims 1992, 7).

As Robinson argues, U.S. policymakers were inclined to see Aristide's victory as both a "fluke" and an affront to U.S. interests. As Aristide attempted to create moderate reforms, including limiting the power of the military and raising the minimum wage from $\$ 3$ to $\$ 5$ a day, elites in Haiti and the democracy promotion network began to push back (Robinson 1996, 292). For the first time foreign aid from the United States was withheld due to concerns over "human rights", even though such aid was routinely distributed during the Duvalier regimes and to the post-Duvalier military rulers whose human rights records were nothing short of abysmal in comparison (Ibid.). As the "democracy promotion" apparatus funding reached new heights in Haiti, the military and Haitian elites conspired to remove President Aristide from power. 
It is at this point that the parallels between Haiti in 1991 and Venezuela in 2002 become striking. Although the U.S. state did not directly overthrow the Aristide regime, a similar pattern exists that demonstrate the role of NED funded organizations like AIFLD and the ACILS (along with other core grantees) in situations where popularly elected leaders run afoul of U.S. interests. That pattern indicates that the U.S. state via the NED and USAID recruit, train, and cultivate the domestic organizations which inevitably lead the coups, rebellions, and eventual overthrow of regimes deemed hostile to U.S. interests. Again, this is based on the concept of "plausible deniability" whereby the U.S. state and groups like AIFLD (and later the ACILS) can avow all knowledge of anti-democratic strategies while at the same time consistently being linked to such groups in a wide range of "practical" or "non-political" activities which bolster the domestic and international legitimacy of organizations.

Thus, is 1991, as in Venezuela in 2002, we see that the American government had advance knowledge of the coup, yet chose not to intervene for strategic reasons (Ibid.). And, just as in Venezuela a decade later, immediately following the coup, U.S. state officials as well as the leadership of NED funded organizations argued that Aristide had brought upon his own downfall while publicly urging the respect for constitutional processes. This is particularly interesting, as following the 1991 coup the U.S. refused to return Aristide to power until 1994 due to a variety of factors discussed below. Further, the head of the NED-created organization that was responsible for accumulating "evidence" of Aristide's human rights abuses (and which led to the suspension of U.S. aid), Jean-Jacques Honorat commented that "[t]he coup was provoked by the comportment of those in power... it was a reaction by the social body politic, and force 
had to be exerted by the only part of the social body politic with arms: the army" (Robinson 1996, 288, quoting an Americas Watch report). Interestingly, Honorat was later chosen as interim president after the coup and then later replaced by the favored U.S. candidate in the 1990 election: Marc Bazin (Ibid.).

The machinations following the removal of Aristide from power in 1991 are complex and better addressed by several other studies devoted to the subject. However, a quick summary of the situation indicates the following. First, after three years in exile in the United States, Aristide is "returned" to power by the U.S. military and President Bill Clinton. However, this was only allowed after Aristide agreed to significant concessions. Specifically, Aristide agreed to privatize industries and implement structural reforms in line with the neoliberal agenda of the IMF, World Bank, and United States. Second, upon his return, mass protests against these neo-liberal policies led the Aristide government to renege on the privatizations, which caused international institutions to retaliate by freezing credit to Haiti (Shamsie 2004, 1101). As Shamsie (2004) and Reding (1996) both note, this is ironically the polar opposite of how a democracy is supposed to function. Aristide refusing to privatize the rightful assets of the Haitian people because it is unpopular with the electorate is how democracies are supposed to work! Yet, in U.S. policy circles and especially within the "democracy promotion" network this was used as evidence of Aristide's obstinacy. Finally, the most important piece of subtext from the return of Aristide to power in 1994 was that he was forced to accept that he had in essence been in power for the previous three years, and thus had to step down from office in 1996 due to a constitutional prohibition on running for office in consecutive terms. It seems clear that by delaying the return of Aristide to the presidency 
for most of his term, and being assured that he could not immediately run again, the "threat" of Aristide's brand of democratic popularity would not threaten the formation of polyarchy in Haiti. However, in the short term, the desire to divide and marginalize Aristide's followers and his vision failed, as Lavalas and other independent groups won the 1995 parliamentary elections (Robinson 1996, 312).

Critically, although Aristide's successor, Rene Preval was inaugurated with the support of Aristide and Lavalas, a schism was developing within the group over the role of privatization and neoliberalism in Haiti (Sprague 2002). As Lavalas shifted towards the more technocratic wing of the party, which along with Preval uneasily began to move towards privatizing industries with his "Democratization by Capitalization" program, and involved joint ventures between the Haitian state and foreign capital, the rift became more pronounced (Ibid. 119). In 1996 Aristide took the remnants of the party which still adhered to its original populist tenants and formed Fanmi Lavalas (FL) which “...was rooted in two principle themes: opposition to neoliberalism, (i.e. privatization) and the promotion of the interests of the poor majority outside the traditional bloc of political parties" (117).

In 2000, Aristide was again elected to the presidency under the FL banner. In an election boycotted by the main opposition and under heavy scrutiny, Aristide won over $90 \%$ of the popular vote. As Sprague points out, the boycott “...was a common strategy used to delegitimize leftist movements that were undefeatable in the vote; a similar tactic was used in Venezuela" (153). Even more to the point, the response by the international community, especially the United States was telling. The day before the inauguration the United Nations pulled its police and human rights missions in Haiti, which followed on 
the heels of the U.S. and Canadian police training missions also being removed from the country (155). The main opposition coalition, largely funded by the IRI via the NED, set up a parallel government and denounced the Aristide government as a dictatorship. Over the next several years the Aristide government was plagued by domestic unrest, crossborder incursions from Haitian rebels based in the Dominican Republic, and most importantly the debilitating effects of a U.S. led freeze on foreign aid and credit.

The election of George W. Bush to the presidency had exacerbated tensions, as the incoming administration pushed for aid to be funneled through NGO's such as the IRI, and charitable organizations rather than through the traditional channels of the state. This was, in effect, an unspoken embargo on the already impoverished Caribbean island. Though better covered by other accounts, it is clear that the IRI played a key role in destabilizing the Aristide government by funneling aid to opposition groups and helping co-ordinate the small but vocal elite that were hostile to Aristide. In 2005, the New York Times ran a story based on interviews with key players involved in shaping U.S. policy towards Haiti. The former U.S. ambassador to Haiti, Brian Curran recounted how he warned the Bush administration that their activities would inevitably lead to accusations that they were attempting to destabilize the regime. More to the point, “...when he asked for tighter controls over the I.R.I. in the summer of 2002, he hit a roadblock after high officials in the State Department and National Security Council expressed support for the pro-democracy group..." which, tellingly was led by Haitian Senator Stanley Lucas, a vehement opponent of Aristide (Bogdanich 2006).

In fact, Otto Reich, the State Department official in charge of the Western Hemisphere at the time, responded to Curran's accusations by admitting that the Bush 
administration was interested in more than preserving the democratically elected regime in Haiti: "[t]here was a change in policy that was perhaps not well perceived by some people in the embassy... We wanted to change, to give the Haitians an opportunity to choose a democratic leader" (Ibid.). It should be noted that as mentioned in the previous section on Venezuela, Reich met with representatives of the Venezuelan opposition including the CTV prior to the short lived 2002 coup. In addition, the New York Times confirmed from numerous other high-level sources that the IRI's man in Haiti, Mr. Lucas, was adamant about the opposition refusing to work with President Aristide in order to "cripple" his government (Ibid.). Thus, the IRI was providing rock-solid support of the Haitian opposition which had made abundantly clear its only goal was to remove Aristide from power yet again.

In February, 2004 as rebels closed in on Port-au-Prince, President Aristide was flown out of the country on a private jet, escorted by U.S. embassy personnel, eventually landing in South Africa where he would reside in exile. The United States claimed, as in 2002 with Chavez, that Aristide had voluntarily ceded power and fled the country.

Aristide, on the other hand, maintained that he was forced to leave Haiti by the United States who in essence, kidnapped him (Stout 2004). Regardless, Aristide was once again out of power.

Though it is clear that the IRI played a major role in supporting elements of the opposition that eventually forced Aristide from power, the work of the Solidarity Center is less transparent. Neither NED nor Solidarity Center Annual Reports mention specific grants in Haiti from 2000 to 2004 . Although it is possible that the Solidarity Center was working in-country during this time period with other grants (with USAID funding for 
example), it is difficult to ascertain more information due to the secrecy which surrounds much of the ACILS activity. In addition, NED funding is often funneled through "regional" grants, which do not stipulate a specific list of countries where the work is to take place. During this period, several block grants for the "Latin American Region" were funded which could have found their way to Haiti. Interestingly, in 2003 the ACILS published a report, which it explains was funded by the National Endowment for Democracy without attribution or specification. Moreover, the 2003-2004 Solidarity Center Annual Report has Haiti highlighted on a map indicating it has a "program" in the country during that time period. In short, it is unclear exactly where the funding for the 2003 report came from as it is not mentioned specifically in any NED report, and it is also unclear whether the ACILS was involved in other activities in Haiti during the period. Regardless, the 2003 report indicates some rough outlines of what the Solidarity Center might have been up to in Haiti prior to the coup. First, there is the inclusion of a significant number of interviews with members of Batay Ouvriye, a radical Trotskyist labor organization (it does not consider itself a typical union) that the ACILS report describes as “...a small, action-oriented organization that uses advocacy, campaigns, organizing, and international solidarity to assist workers facing a violation of the Labor Code" (Solidarity Center 2003, 4).

The inclusion of a significant number of interviews with Batay Ouvriye is in and of itself somewhat of an anomaly. The fact that the ACILS would later work with the organization is even stranger. Since the founding of the AFL, the organization has partnered with a large number of labor organizations in its foreign policy. However, the AFL-CIOs partners abroad have universally been drawn from very moderate or 
conservative labor unions. And, as history has shown, if a country did not have such a union the AFL-CIO institutes were often willing to create one. One of the connecting strings that run through Federation foreign policy has been a virtual ban on working with unions of the left. As discussed in chapter two, during the Cold War the Federation's foreign policy was specifically aimed at undermining leftist labor organizations. In Venezuela, in seems clear that the CTV was chosen as a partner for the ACILS specifically because they were not aligned with the modest socialism of the Chavez regime.

However, Batay Ouvriye seems to be the lone exception to this rule. More importantly, Batay Ouvriye is not just oriented towards the left, it is a radical organization that in its own words "....is an alternative to the traditional bureaucratic, corrupt union movement that upholds the dominant classes' power amongst the exploited masses of Haiti” (Batay Ouvriye 2012). Researcher Jeb Sprague explains that Batay Ouvriye is an anarcho-syndicalist organization (which Batay Ouvriye denies) while other scholars have referenced them as a "Trotskyist" organization (Sprague 2005).

Regardless, while the AFL-CIO has steadfastly refused to work with leftist labor unions in the past, in Haiti they have been linked to an organization that seems to eschew the business unionism principles the ACILS generally espouses. However, by examining the NED and Solidarity Center reports from 2005 this relationship begins to make much more sense.

The first specific grant mentioned for Haiti in an NED or Solidarity Center report since the creation of the ACILS in 1997 is found in 2005. Again, it is fairly clear, given the 2003 report on the labor situation in Haiti as well as the involvement by other core- 
grantees in Haiti that the ACILS was involved in some activities in the Caribbean nation, most likely found under a non-specific regional grant. However, in 2005 the ACILS received a grant via the NED for $\$ 99,965$ to:

...promote the development and capacity of democratic unions in free trade zones. ACILS will work with the May 1st Union Federation, Batay Ouvriye, to train workers to organize and educate fellow workers. Training will include how to develop organizational plans, network with workers outside their factories, form community and factory unions, and research and monitor working conditions. Finally, NGOs and trade unions from the United States and Canada will visit to discuss working conditions in Haiti (NED 2005).

In addition, in an interview conducted by researcher Jeb Sprague in February, 2006, the regional director for the Solidarity Center confirmed that the ACILS was also awarded another $\$ 350,000$ grant directly from the U.S. State Department's "Democracy, Human Rights, and Labor Department" in May of 2005 to work with Batay Ouvriye (Sprague 2006a). Contrasted with Batay Ouvriye's own statements regarding its organizational philosophy and its stated opposition to working with all governments, especially the United States, this partnership whereby the ACILS funneled a total of nearly $\$ 450,000$ in grants to Batay Ouvriye, makes little sense. However, research done by Jeb Sprague and others as well as correspondence between the Batay Ouvriye and other radical organizations sheds some light on the matter.

First, in the weeks and months following the 2004 coup, violence that been slowly increasing against Lavalas supporters since 2000 became institutionalized under the interim regime. A 2004 University of Miami Human Rights Report stated that:

Haiti's security and justice institutions fuel the cycle of violence. Summary executions are a police tactic, and even well-meaning officers treat poor neighborhoods seeking a democratic voice as enemy territory where they must kill or be killed. Haiti's brutal and disbanded army has 
returned to join the fray. Suspected dissidents fill the prisons, their Constitutional rights ignored. As voices for non-violent change are silenced by arrest, assassination, or fear, violent defense becomes a credible option. Mounting evidence suggests that members of Haiti's elite, including political powerbroker Andy Apaid, pay gangs to kill Lavalas supporters and finance the illegal army (Griffin 2004).

Thus, nearly immediately after seizing power the coup leaders killed and jailed Lavalas and Aristide supporters with impunity and without reproach from the U.S. state, which incidentally had been very concerned about human rights abuses under Aristide and often cited such violations as being supporting evidence for his second ousting. The international media also paid little attention to these developments. For example, Jeb Sprague in an article for FAIR notes that:

The New York Times published 642 pieces that mentioned Haiti between March 1, 2004 and May 1, 2006 - close to one a day. But only four dealt with the violence against and persecution of members and supporters of the former government. While the New York Times reported (10/26/04) on the imprisonment of Father Gerard Jean-Juste, a pro-Aristide priest imprisoned for political reasons, it failed to investigate the nearly 1,000 other political prisoners, many underfed and living in dilapidated jails for more than two years without being charged (2006b).

Popular labor organizations, including the Confederation of Haitian Workers (CTH), were repressed in the crackdown against Aristide and Lavalas supporters, with leaders arrested and members threatened. In addition, approximately 12,000 public sector workers, hired under the Aristide regime, were fired in the post-coup wave of repression and intimidation (MacDonald 2005). However, in this climate of state-sponsored terror against popular forces, the ACILS remained strangely silent and instead of rallying to protect the victims of this persecution “....supported a labor organization [Batay Ouvriye] that agitated for the ousting of the democratically elected government of Jean Bertrand 
Aristide" (Worker to Worker 2006). When directly asked why the ACILS had said so little regarding the post-coup wave of intimidation and violence against labor organizations, Teresa Casertano, regional director of the Americas for the Solidarity Center responded ““[w]e make public statements. We make plenty of statements” (Sprague 2006a). However, neither Sprague nor this researcher could find any statements by the ACILS condemning the post-coup repression against organized labor. The larger question being asked by scholars and activists was why this organization was being funded by the ACILS and for what purpose?

In another article published in 2005, Sprague delved into the issue of the Batay Ouvriye-Solidarity Center relationship, noting that he had interviewed the former U.S. labor attaché to the U.S. embassy in Port-au-Prince who remarked that during his tenure (2000-2001) "I tried to involve the Solidarity Center but they refused to work in Haiti at this time" (Sprague 2005, 2). Interestingly, Sprague noted that the 2003 NED funded study of the Haitian labor situation published by the ACILS:

...utilized Solidarity Center interviews with the Batay Ouvriye that predated to 1999 . The study failed to critically analyze the role of USAID and the U.S. in supporting sanctions against the Haitian government in 2001, which was a prime factor for the shortfall of payments to the public workforce and leverage used towards the Free Trade Zone Initiative. The study... relied heavily on interviews with the Batay Ouvriye, the formerly Duvalier sponsored Federation des Ouvriers Syndiques (FOS), and the formerly AIFLD-supported Conféderation Autonome des Travailleurs Haïtiens (CATH) (Ibid.).

One thing Sprague did not mention in his research was that the 2003 ACILS report on Haiti noted the coalescence of these labor organizations against proposed changes to the Haitian labor code: 
In July, 2000, worker support organizations, including Anten Ouvriye, Batay Ouvriye, Action Catholique Ouvrière (ACO), Chandel, Tet Kole Ti Peyizan, and the Port-au-Prince branch of the Justice and Peace Commission, formed a coalition to challenge the proposed Labor Code. A Creole document critiquing the draft legislation was prepared. It was distributed throughout the country with a view to planning workshops with workers in both rural and urban areas and organizing a national, broadbased campaign against the proposed legislation (Solidarity Center 2003, $64)$.

Many (if not all) of these organizations were in open opposition to the Aristide presidency and were linked together through a variety of statements condemning both Aristide and later the MINUSTAH forces as well as the U.S. involvement in Haiti post2004. The head of the ACO, Ferguens Lormeus, was a signatory on a document asking the Jamaican people to demand that Aristide not be allowed to visit Jamaica in 2004 because (among other things) "[t]he presence of Jean-Bertrand Aristide close to Haitian shores threatens to destabilise the process that has been set in motion" (Statement of Assemblies of Caribbean People 2004). Anten Ouvriye is the research organization attached to Batay Ouvriye, and thus an obvious political ally. In short, these workers and peasant organizations are linked together, by if nothing else, their anti-Aristide positions and the interviews in the 2003 report rely heavily on these organizations.

Thus, the 2003 Solidarity Center Report is instructive in several regards. The ACILS was working with, or at the very least had connections with, Batay Ouvriye as early as 1999. In addition to Batay Ouvriye, the ACILS report mentions several other organizations united in their opposition to labor reform under the Aristide government that also formed a "coalition" sometime before or during 2003. At a time when the Aristide government was besieged on all sides; with a practical embargo by the U.S. state 
on aid distribution, well-armed rebels crossing into Haiti from safe haven in the Dominican Republic and carrying out attacks against the regime, and a sophisticated campaign by the opposition funded by the IRI, this sort of coalition would be just one more nail in the proverbial coffin of the Aristide government. It would signify that segments of the radical left were opposed to the regime and thus bolster the arguments of the IRI funded organizations that were pushing for Aristide's ousting.

Although Batay Ouvriye had been very successful organizing garment workers in Free Trade Zones, a noble and positive activity in an industry that pays very little, it did not meet any of the usual requirements for working with the Solidarity Center. Moreover, the ACILS would inevitably have to discuss with its patrons at the NED and USAID why the radical Batay Ouvriye was a good partner for furthering "democracy promotion" in Haiti. Regardless, by 2005 the ACILS was able to obtain funding via the NED to the tune of $\$ 99,965$ and through the State Department directly for another $\$ 350,000$. Jeb Sprague articulates the theory that this was part of a strategy by the ACILS to divide the left, which would have likely coalesced to oppose another intervention from the U.S. unless Aristide was somehow deemed "worse" than the prospect of a U.S. invasion. Thus, as Sprague writes:

But for all its good work in organizing in the garment industry, one important theme separated Batay Ouvriye from the majority of popular organizations in Haiti. Batay Ouvriye was adamantly and ideologically opposed to any cooperation with the Aristide government, or for that matter any leftist or populist government that was democratically elected. With its backing for the Batay Ouvriye, the Solidarity Center was able to kill two birds with one stone. (1) The Solidarity Center was able to claim the credentials of supporting a legitimate labor struggle to organize workers in Haiti's miserable garment industry. (2) While simultaneously supporting a group that adamantly opposed and organized against the 
largest and most popular party of the poor in Haiti, Fanmi Lavalas, a pariah for Haiti overseers at the U.S. Department of State (2005).

James Jordan took note of these trends and remarked on how strange it was for the ACILS to ignore the repression aimed at organizations like the $\mathrm{CTH}$ while supporting Batay Ouvriye writing that "[r]ather than helping this most targeted union $[\mathrm{CTH}]$, the Solidarity Center channeled hundreds of thousands of dollars to a small labor organization that before and during the coup did nothing to defend the elected government and, in fact, called for Pres. Aristide to step down” (Jordan 2012). Interestingly, Jordan goes further in pointing out:

Years later, by 2009, when the CTH changed its positions and approved a proposal for factories that paid half the minimum wage established by the Aristide administration, the Solidarity Center began to fund the CTH with grants of more than $\$ 200,000$. With such funding, the CTH also changed its electoral associations and participated in the Preval administration electoral council that excluded the participation of Lavalas, Aristide's party, in the elections despite it being Haiti's largest political party (2012).

By examining the NED Annual Reports, it is clear that the ACILS received $\$ 250,000$ in 2008 and another $\$ 300,000$ in 2009 for work with unnamed Haitian labor organizations. According to the Solidarity Center reports, at least some of these funds were used to research the exploitation of Haitian workers inside the Dominican Republic (Solidarity Center 2008; 2009).

The relationship with the Solidarity Center also provoked condemnation by Batay Ouvriye's allies on the left, who seemed to agree with the proposition put forward by Sprague. In an open letter to the BO dated May 19, 2008, the League for the Revolutionary Party, a U.S. based Trotskyist organization writes that: 
BO has stated opposition to the current occupation forces in Haiti, but in 2004 it did not take a stand against U.S. imperialism's ouster of Aristide. What it did do was equate the Aristide regime with the bourgeois opposition to Aristide -- at the exact time that the U.S. was ousting Aristide with the active support of much of the Haitian bourgeois opposition. BO's political opposition to both bourgeois sides was correct in itself but they used the equation of the bourgeois Aristide regime with the bourgeois opposition as an excuse to taking no side in the specific conflict between the Aristide regime and U.S. imperialism over who has the right to govern Haiti (Daum, 2008).

In response to the allegations raised by Sprague's research and the questioning that followed, Batay Ouvriye released several statements on their relationship with the ACILS. Heavily laden with personal attacks on Sprague, the BO argued that "[w]e have always pursued and engaged in relations of solidarity, whether militant or financial, on the basis that they relate to struggles and practices based solely on our deep convictions and in total independence of orientation and functioning" (Batay Ouvriye 2005a). Batay Ouvriye vehemently denied any active involvement in the ousting of President Aristide however. And, though it is clear BO was opposed to both Aristide and Lavalas, who the BO saw as repressing labor in the favor of transnational interests and dominant local elites, there is no evidence to support claims that the labor organization was involved in the uprisings that resulted in the removal of Aristide. The funding of BO through the ACILS clearly occurred after Aristide was relocated to South Africa, although the 2003 Solidarity Center report clearly indicates there was collaboration between the two organizations as early as 1999.

Later in 2005, Batay Ouvriye released another statement that "clarified" their main points of contention with Sprague's investigation of the Solidarity Center grants. The document again reiterates that Batay Ouvriye operates independently and will accept 
support, both material and spiritual, from any quarter. However, this clarification also contains a scathing critique of AFL-CIO policy abroad:

In light of the concrete relations the AFL-CIO maintains with a great number of workers throughout the world, we fight for them to clearly understand this apparatus' role, all the while building the workers' real unity on the basis of their interests. We denounce the AFL-CIO's negative practices in direction of the workers, as well as the manipulative, collaborationist, bureaucratic line it diffuses in the worker milieu. We denounce the AFL-CIO's insertion in international level struggles and its relation with the government and the American state. We denounce its nature (all of these positions are clearly expressed and diffused on our website so all, and progressives particularly, may not be deceived). The AFL-CIO is only an example, for we always function in this way in our relation with other organizations (Batay Ouvriye 2005b).

Finally, in October 2008, Batay Ouvriye released a scornful appraisal of the Solidarity Center explaining that all ties between the two organizations had been severed. More to the point, BO explained that although the relationship started “....in the context of concrete workers struggles..." that the Solidarity Center sought funding for this relationship and:

...that was the root of all the trouble: the funds originated from the NED, an imperialist agency that tries to thwart popular struggles all over the world, and the Solidarity Center itself has taken an active part in various reactionary imperialist plots, particularly in attempts to overthrow Chavez among others (Batay Ouvriye 2008).

Furthermore, Batay Ouvriye argues that its relationship with the ACILS was based upon BO's desire to subvert ACILS activity in the region, writing that:

Before, as part of our relations, Batay Ouvriye was engaged with various other organizations in other countries where the Solidarity Center was trying to immix itself in workers struggles. This was an avenue that Batay Ouvriye used to fight against the Solidarity Center's influence, to thwart their attempts to co-opt workers struggles and to reorient these struggles in the workers interests. Although this double struggle was fraught with difficulties, we had managed to make some headway... In effect, in its 
attempt to replace AIFLD throughout the world, the Solidarity Center is replicating AIFLD's old practices... In our struggles against the Solidarity Center, we always denounced its role in the global imperialist agenda. These struggles took various forms. Not only did we denounce them in our autonomous struggles, but when we could, we also forced them to answer to the denunciations others made of them. Till the end, they never took a clear stand, publicly, for everyone. That was the case about their practices in Venezuela and Chavez. Their silence further confirmed their reactionary activities... The Solidarity Center has access to substantial funds through its implication with imperialist subversion. It receives money in the name of other organizations while it only gives them a pittance. That's how some of its members are living it up on the backs of workers while trying to co-opt, corrupt and subvert workers movements. We denounce these practices in general and we denounce their practices with us. From a total of $\$ 440,000$ they got from the NED in our name, we only received $\$ 90,000$ while they kept $\$ 350,000$ ! On top of that, they simply refused to give us the remaining $\$ 6,000$ that had been granted to us and they simply used it for their own needs. Not only are they doing the bidding of imperialism, but they also maintain imperialist relations of domination with those organizations with which they are involved. We forced them to take clear positions vis-à-vis their superiors and through statements we issued. There again they balked (Ibid.).

The Solidarity Center, for its part, does not mention the significance of the relationship with Batay Ouvriye in its Annual Reports. A search of ACILS' archived Annual Reports finds no mention of Batay Ouvriye, while the group merits just a passing mention in two updates on the ACILS website as one of many organizational partners in Haiti. The only specific statements the ACILS has made regarding grants dispensed in Haiti during this time period occurred in interviews with Sprague, which highlighted the linkages between the State Department and the ACILS as well as a vague explanation of what the programs entailed:

Teresa Casertano, regional director of the Americas for ACILS, managed the grants. She explained, 'We provide a service that is an educational service, to train them, to share with them our knowledge and skills on trade union organizing... Organizing members, doing new member orientation, collective bargaining, contract enforcement, shop stewards... 
As part of the grant requirements ACILS was to submit quarterly evaluation reports to its funding sources the NED and U.S. State Department." Casertano recalled, "We wrote a proposal that was submitted. A very standard format with objectives, activities and evaluation procedures... So there was a grant agreement based on that, the State Department dispersed funds for those activities described...The specific grant has a quarterly reporting requirement... We then write that up and we submit it as a quarterly report." In this particular program with the Batay Ouvriye, the U.S. State Department asked to extend the program, as Casertano observed, 'They did ask us to extend it from a year long to 18 months with the same amount of funding and we agreed... [AFL-CIO Senior Advisor to the ACILS, Harry] Kamberis further explained the cooperation between the State Department and ACILS: 'The State Department has annually a labor officer conference that we are invited to come and speak at and also when they have labor officer training programs they send the officers over to speak with us. We design our own programs and run them. But we do talk with the State Department. We exchange information and we help them with information on their annual labor and human rights reports (Sprague 2006a).

Thus, the activities of the ACILS in Haiti remain somewhat murky. However, a few clear conclusions can be drawn from the information presented here. Unlike the situation in Venezuela that unfolded post-1998, where polyarchy was crumbling under the forces of popular democracy, Haiti presents a case that indicate a decades long attempt by the U.S. state to implement "limited" democracy against popular democratic pushback. Although the track record of AIFLD in Haiti is clear, the role of the ACILS is much more nuanced. As much of the criticism of the ACILS' relationship with Batay Ouvriye explains, it seems highly plausible that this affiliation was born out of a desire to split the organizations on the left that opposed the Aristide government for not being radical enough, and thereby align their interests with the more conservative elements cultivated by the IRI that believed Aristide to be too radical. 
Thus far, the cases of Venezuela and Haiti have presented two very different compelling arguments that indicate the foreign policy of the AFL-CIO is most powerfully explained by the exigencies of the U.S. state. In Venezuela, the "democracy promotion" project of the NED involved an attempt to re-create polyarchy after its breakdown in the face of popular democracy. However, in Haiti the situation was quite different, as the promotion of "limited democracy" has proceeded in fits and starts over the last three decades. Thus, in the Haitian context, the goal has been to establish polyarchic rule in the face of popular democratic pressures while in Venezuela the impetus has been on recreating the previous order. However, in the next and final case study I argue that the U.S. state-NED-Solidarity Center nexus indicates that the "war on terror" initiated in the post 9/11 environment demonstrates the significance of American foreign policy on the activities of the ACILS. Rather than a single case study, the countries represented in the following sections are examined according to broad trends that reinforce the relationship between the U.S. state and the ACILS.

\section{IRAQ, THE MIDDLE EAST AND THE "WAR ON TERROR”}

One of the most interesting areas of symmetry between the Solidarity Center and U.S. foreign policy is found by looking at the role the ACILS has played in the Middle East and North African (MENA) region since 2001. Though there is less detail available as to the exact nature of much of this work, the large-scale shifts in NED funding for the Solidarity Center to projects in the MENA region coincide neatly with the onset of the "war on terror" when U.S. military spending spiked alongside the second Gulf War. As early as December, 2001 discussions were had at the U.S. State Department on the need 
for "labor diplomacy" in the Middle East as a counterpart to the "war on terror." As Kim Scipes noted, citing a 2001 State Department report on the role of "labor diplomacy" in the Middle East:

As the U.S. Government-supported programs of the American Center for International Labor Solidarity (Solidarity Center) already demonstrate, a policy that aims to cultivate union leadership at the enterprise and industrial sector levels represents the most promising approach to inculcate modern economic thinking and democratic political values among workers in Muslim countries (Scipes 2009; ACLD 2001).

This report goes on to encourage increased funding for such programs by the State Department as being vital to fighting terrorism, something that clearly occurs by looking at the spike in MENA funding for the Solidarity Center following 2001.

In particular, ACILS activity in Iraq indicates the depth of divergence between rank and file domestic attitudes toward U.S. foreign policy and the Solidarity Center's activities abroad. While Federation membership largely opposed the war, the ACILS accepted some of the largest NED grants ever funded to work in occupied Iraq. Finally, while the ACILS activity in Iraq fell under greater scrutiny from AFL-CIO members, at the same time the Solidarity Center was also accepting large sums of funding from the NED to operate in other MENA states vital to the war on terror and the larger "democracy promotion" project of the Bush administration. Though these operations were largely ignored by the rank and file due to the prominence of Iraq in media accounts, they nonetheless indicate the degree to which ACILS policy is shaped by U.S. foreign policy.

As discussed briefly in chapter 3, the MENA region, as the NED refers to the Middle East and North Africa, saw a staggering increase in funding for Solidarity Center 
programs beginning as early as 2002 . In fiscal year 2001, the MENA region accounted for just around $3 \%$ of all the funding the ACILS received from the NED. Although most of the funding that the Solidarity Center received in 2001 came from "other" Federal sources (most likely USAID), in 2001 the NED funded over $\$ 4.5$ million ACILS grants worldwide yet only one was for the MENA region for ACILS use, for $\$ 144,412$ “[t]o assist women trade union leaders in Jordan, Lebanon and Morocco, to improve their skills and influence through strategic planning, educational sessions, workshops and publications" (NED 2001). In 2002, NED grants for doubled for the region, under the vague purposes of helping "workers to participate in the building of democracy in Middle East unions, workplaces, and society" (NED 2002).

By 2003, with George W. Bush describing Iraq as the central front in the war on terror, the ACILS received grants totaling $\$ 860,000$ for work in the MENA region, with most of these funds being used "[t]o establish a regional presence in Amman, Jordan. The institute will work bilaterally and multilaterally with labor organizations and likely allies in Jordan, Lebanon, Yemen, Bahrain, Kuwait, and potentially Iraq to address democracy building, transparent unions, and building advocacy skills among workers to represent their interests" (emphasis added) (NED 2003). The language used here is most instructive: the ACILS is setting up a regional hub in the Middle East at the exact same time the U.S. state is planning "regime change" in Iraq and threatening other Middle Eastern states with similar treatment. This correlation defies coincidence, especially considering that Iraq is mentioned as a "potential" project. The 2003-2004 ACILS Annual Report proudly acknowledges that "[w]e launched a new Middle East office in Washington D.C., and a field office in Amman, Jordan" (Solidarity Center 2004). Thus, 
while the ACILS continues to maintain its neutral, independent, and private nature, it is striking that the establishment of the Amman regional office in the fall of 2003, just months after the U.S. invasion of Iraq, was intended as a base of operations to coordinate activities following on the heels of U.S. state interventions in the region. Again, the argument here is not over whether this activity by the ACILS is normatively "good" or "bad" but rather it indicates that Solidarity Center activity is following the lead of the U.S. state.

The focal point of much of the scholarship addressing the AFL-CIO and the "war on terror" has consistently revolved around rank and file support (or criticism) of the 2003 U.S. invasion of Iraq and the response of the Sweeney administration to these demands. Many noted that when the AFL-CIO officially came out with a resolution demanding the rapid return of American troops in 2005 it was the product of grassroots struggles against the vacillation of top leadership (Sears 2010; Scipes 2011). The 2005 resolution by the Federation surely was a defining moment in AFL-CIO history as previously the Federation had officially supported every single war waged by the U.S., including the polarizing Vietnam conflict. However, it is important to note that this resolution only passed in 2005, two years into the occupation of Iraq by U.S. forces.

During the run-up to the initial invasion however, the Sweeney administration wavered between tacit support for military force and opposition to invasion. In a January, 2003 letter, both John Sweeney of the AFL-CIO and John Monks of the British Trade Union Congress urged President Bush and Prime Minister Tony Blair to allow more time for weapons inspectors and the United Nations to work towards a peaceful compromise in regard to Iraq, writing: 
We fully support putting maximum pressure on Iraq to do so, and believe that the actions taken thus far by both our nations working through the UN Security Council to force a renewal of the inspection process and to demand that these inspections resolve this issue has been the right course (Sweeney and Monks 2003).

However, on the day of the invasion of Iraq the AFL-CIO released a short statement by the Sweeney administration that indicated general support for the war effort, stating that although the Federation had believed the best resolution would have been through a broad based UN initiative "[n]ow that a decision has been made, we are unequivocal in our support of our country and America's men and women on the front lines as well as their families here at home" (Sweeney 2003a). Interestingly, this short statement released by President Sweeney was accompanied by a not-for-publication memo where Sweeney criticized the Iraq invasion, writing that:

Attached is the statement that I released today on behalf of the AFL-CIO regarding the war in Iraq. When our nation is at war I strongly believe that we need to come together in support of our troops on the front lines. Nevertheless, I do not believe that President Bush's insistence on military action rather than further diplomatic efforts serves our nation well... (Sweeney 2003b).

Thus, the AFL-CIO leadership was somewhat conflicted about the invasion of Iraq, opposing it in private but obligated to publicly emphasize its support for American troops (Fletcher 2005, 266).

However, unlike previous conflicts where anti-war rank and file were pushed aside as the Federation rallied around the flag, this time a grassroots movement to denounce the war emerged immediately. The most prominent organization, U.S. Labor Against the War (USLAW) began as a small movement organized by the Teamsters Local 705 in Chicago. However, by the middle of 2005 it included “.... coalition of over 
110 unions, central labor councils, state federations, and other labor organizations" (Zweig 2005, 62). As the power of USLAW grew, the Federation said little no nothing about the Iraq war publicly. In fact, a search of the AFL-CIO website from 2004 shows no mention of the Iraqi war or occupation, even though it has an entire section dedicated to the George W. Bush. Furthermore, as Zweig points out, during the presidential election of 2004 " ...the AFL-CIO provided no training to canvassers on how to address the Iraq war," while Federation leadership focused instead on domestic issues and support for John Kerry (Ibid.). USLAW meanwhile, kept up the pressure on the AFLCIO leadership, and in July, 2005 the “...AFL-CIO convention adopted a resolution for rapid withdrawal of U.S. forces from Iraq, the first time the Federation has ever opposed an ongoing U.S. war" (Ibid.). However, a slightly lesser known resolution was unsuccessful at the convention. As Shorrock notes, the unsuccessful resolution was:

...advanced by the California Federation of Labor with the support of a dozen other labor councils, calling on the AFL-CIO to make a thorough examination and public explanation of its foreign policy activities, from the Cold War to the present, and to "exercise extreme caution" about seeking or receiving money from instruments of U.S. foreign policy, particularly the National Endowment for Democracy and the U.S. Agency for International Development (USAID) (Shorrock 2005).

This description of the convention has important consequences for the relationship of the ACILS and the U.S. state. As the pressure grew on Federation leadership to break with U.S. foreign policy regarding the war, it could not cobble together support for a full accounting of the foreign policy of the AFL-CIO. This is evident in the fact that although the Federation was now demanding an end to the occupation, it had little to no effect on the activities of the Solidarity Center in Iraq. In 2004 the ACILS received its first grant 
for work in occupied Iraq to the tune of $\$ 1,498,014$ (NED 2004). This was part of a massive increase in funding for "democracy promotion" by the NED in 2004 that totaled \$2.6 million in ACILS grants in the MENA region. On top of grants for Iraq, funding was also funneled via the ACILS for work in Yemen, Lebanon, Egypt, and the West Bank and Gaza (Ibid.).

In 2005, the MENA region accounted for $32 \%$ of all NED grants to the Solidarity Center and included another \$1 million grant for ACILS work in Iraq. In 2006 and 2007 Iraq continued to receive extraordinarily large grants for projects in Iraq, including $\$ 700,198$ for work with the General Union of Oil Employees in 2006, and another $\$ 1.5$ million in 2007 for training and support of Iraqi unions (NED 2006; 2007). In short, while the AFL-CIO line in regards to the occupation and the deployment of troops moved to opposition of the war in 2005, the ACILS was still taking millions of dollars to work in occupied Iraq. Finally, in 2008 after being funded with over $\$ 5$ million in NED grants for Iraq in the previous 4 years, the Iraqi specific grants suddenly stop, at the same time U.S. forces begin to be pulled in large numbers from the country.

In terms of what the ACILS was doing on the ground in Iraq, the picture is somewhat muddled. It is clear that the ACILS was involved, for example, in supporting Iraqi labor organizations that were repressed by the transitional government, possibly even to the chagrin of the U.S. policymakers. However, there is a clear discrepancy between the stated independence of the ACILS from the U.S. state and the actuality of the ACILS accepting some $\$ 5$ million in funding to work in Iraq even after the AFL-CIO was calling for the an end to the war. The ACILS inclusion in the "democracy 
promotion" program for Iraq seems on its face value to question its independence regardless of whether the normative outcomes in Iraq were beneficial to Iraqi workers.

Meanwhile, as Iraq dominated the headlines due to the war, the ACILS was also garnering huge sums of money to work in other areas of strategic interest to the U.S. state in the "war on terror" including Yemen, Egypt, the West Bank and Gaza, Algeria, and Afghanistan. Along with the surge in funding for Iraq, the targeting of other MENA states makes perfect sense for U.S. geostrategic aims. As William I. Robinson argued:

The "democracy promotion" agenda that began in Iraq is actually part of a larger "four step" plan for the entire Middle East, announced by Washington in 2003, using its occupation of Iraq as leverage. The first of these steps was a resolution of the Palestinian-Israeli conflict (the "road map" has, of course, since collapsed). The second was a "Middle East Partnership" to "build a civil society" in the region. Such "civil society" programs typically attempt to groom new transnationally- oriented elites, and in this case, to incorporate the Arab masses into a civil society under the hegemony of these elites. The third was the region's further integration into the global economy through liberalization and structural adjustment. And the fourth was preventing the rise of any regional military challenge to the emerging US/transnational domination. The overall objective was to force on the region a more complete integration into global capitalism (Robinson 2004, 441-2).

Robinson's point is clear, whereas previously the MENA region had been connected with U.S. (and transnational economic) interests via a small ruling clique of authoritarians, the invasion of Iraq and the "democracy promotion" program was intended to implement polyarchic rule in the region in the same manner as in Latin America and Eastern Europe in the 80s and 90s (443). By cultivating elites under the tutelage of American "democracy promotion" organizations, the creation of a stable, neo-liberal Iraq could progress smoothly. Furthermore, Robinson presciently notes that: 
We may see in Iraq another modus operandi of US political intervention, in which US operatives choose for strategic reasons to work through thirdcountry groups. For instance, in its extensive political intervention activities in Nicaragua in the 1980s the US "democracy promotion" apparatus worked through a number of Venezuelan political and civic organizations. Proxy Venezuelan operatives actually conducted programs on the ground in Nicaragua. As Spanish-speaking Latin Americans, these operatives were able to achieve a level of legitimacy, penetration and influence impossible for gringos. In Iraq, therefore, the US may choose at some point to mount political intervention programs via Jordanian, Egyptian, and other Middle Eastern-based groups. Those monitoring political intervention in Iraq will want to look out for the creation of NGOs in the country (we are likely to see a dramatic NGO-ization). While many of these may be authentic Iraqi and foreign groups, others will undoubtedly be part of the US-mounted political intervention network (445).

Thus, while Iraq remained a focal point for anti-war Federation members (via USLAW and other grassroots organizations domestically), the larger picture indicated that the ACILS was heavily involved in "democracy promotion" programs all over the MENA region tied into the war on terror and the Bush administrations democracy-throughregime change plans. In other words, the disconnect between the AFL-CIO position on the war and the ACILS activities in some ways obscured the larger shift of Solidarity Center activity to the MENA region, where just two years earlier it barely existed. Again, this does not demonstrate a causal relationship; however it does lend correlative indications that the ACILS is heavily involved in following U.S. foreign policy aims.

It is critical to note then, the proliferation of NED-funded ACILS programs in the MENA region beginning around 2003. First, as mentioned above there is the creation of the regional operation center in Amman in 2003. In 2004, the NED funded a program “[t]o establish an Egyptian Trade Union Technical Organization (ETUTO)" while 
$\$ 597,045$ went to programs to "reach out and engage a broad range of unions and federations" in Egypt, Yemen, Lebanon, and the West Bank and Gaza as well as Jordan (NED 2004). The following year, more of the same followed with grants directed at Egypt, the Gulf States, Bahrain, and Yemen, while another $\$ 570,000$ went to open another regional office in Algiers to "plan and organize activities in the Arab Maghreb" (NED 2005).

In a period of just three years, the ACILS went from having very little NED funded projects in the entire MENA region to having both a Middle Eastern organizational hub (Amman) and a North African regional office (Algiers). Clearly, the ACILS was setting up for what looked to be a long partnership with NED funds in the post 9/11 era. In 2006, $\$ 84,119$ was granted for ACILS work to "identify future Libyan labor leaders", another $\$ 99,026$ for strengthening journalist unions in Tunisia and networking them with journalists from Algeria, Morocco, and Egypt (NED 2006). Another $\$ 603,000$ went to help Algerian and Tunisian union members "respond properly to economic changes" (Ibid.).

By 2012, when Tunisia, Egypt, and Libya had experienced democratic uprisings scholars and activists began to question what role the ACILS "democracy promotion" activities had played in destabilizing regimes. No question, many of these regimes were authoritarian and repressive. However, as I have stated before, this dissertation is looking at the connections between U.S. state interests and the ACILS, and is not attempting to categorize ACILS activity into subjectively "good" or "bad" categories.

In Egypt, Michael Barker noted that a 2010 Solidarity Center report on the labor situation in Egypt used NED-funded organizations almost exclusively for its data and 
ignored completely the role of the U.S. state in propping up the regime of Hosni Mubarak (Barker 2011). Besides the ACILS's heavy reliance on information gleaned from other NED funded groups in Egypt, Barker argues that:

Moreover, for what ostensibly passes as a labor report...it is truly astounding that Beinin [the author] only makes one vaguely critical statement about the US government within the entire document. This passing concern with the United States comes on page twenty-seven, whereby he talks about the anti-democratic role of the Egyptian security authorities in intervening to impede the activities of independent labor organizations, which he suggests "is comparable" to the work undertaken by the FBI in the United States. By way of a contrast to this minor criticism (if one could even call it that), the rest of Beinin's report has only positive things to say about US influence in the Middle East. In fact, the next time that he mentions the U.S. it is to praise their government's good work, and the "reasonable" work of US-directed factories (which should read: sweatshops) in Egypt (3).

Barker goes on to illustrate how the ACILS report criticizes the relationship between the Egyptian state and the Egyptian Trade Union Federation without realizing the irony of such an attack; specifically the relationship between the Solidarity Center and the U.S. state (Ibid.). More to the point, Barker takes the ACILS report apart piece by piece, pointing out again and again that the organizations discussed and the interviews and experts cited by the Solidarity Center report all have significant ties to other NED-funded programs. The end result is an ACILS report on the labor situation in Egypt that emphasizes the benevolent role of the U.S. state and U.S. multinationals in the Egyptian labor movement.

Furthermore, other scholars noticed a distinct shift in the types of labor organizations funded by the ACILS in Egypt. Though their article is one that is uncritical of the larger project of democracy promotion, and in fact argues for ways to strengthen it, 
Snider and Faris note that prior to 2003, when U.S. support was fully behind the regime of Hosni Mubarak, the ACILS apparently was willing to use USAID funds to work with the same state-aligned labor federation that the 2010 Solidarity Center report works so hard to discredit:

While a previous Solidarity Center project between 2001 and 2003 (funded by USAID) appeared to work exclusively with the state-aligned ETUF, it appears that later incarnations of this work have supported the drive for labor unions independent of the state, and the AFL-CIO itself prominently supports this goal. While one would not want to attribute causality to these programs, they do demonstrate that U.S. democracy promoters correctly identified potential challengers to regime supremacy and undertook programs designed to empower them (Snider 2012).

In short, the Egyptian democracy movement has significant roots in the activities of NED funded organizations, especially the Solidarity Center. While this has been only a sketch of the rough contours of how the Solidarity Center's relationship with the NED and the U.S. state has expanded to the rest of the MENA region, it seems clear that as further details emerge regarding the "Arab Spring" in the coming years, scholars will see more and more linkages between the "democracy promotion" programs of the ACILS and the creation, or attempted creation, of polyarchic regimes in the region.

In sum, the correlation between the Solidarity Center and the U.S. state in the MENA region is further indication that the relationship between the US state and AFL$\mathrm{CIO}$ foreign policy is deeply ingrained. As in the cases of Haiti and Venezuela, there is no "smoking gun." However, the "democracy promotion" program is adverse to such direct connections. The promotion of polyarchy eschews direct linkages between the desired outcome of the U.S. state and the organizations in question, and prefers to create and cultivate the organizations and actors that see U.S. interests as their own. Thus, this 
dissertation can be thought of as a first cut in understanding how the ACILS's relationship with the U.S. is marked by continuity (in terms of following the lead of the state) at the same time its tactics have changed.

\section{CHAPTER SUMMARY}

The case studies illustrated in this chapter build upon the foundation begun in chapter three by moving beyond the broad funding flows, which indicate a congruence between U.S. foreign policy and Solidarity Center activity, to examine how dissimilar cases support the central proposition of this work: that the foreign policy of the ACILS is best explained by the exigencies of the U.S. state. These case studies indicate that the Solidarity Center's central role as a core-grantee of the NED in the MENA region, Venezuela, and possibly in Haiti looks much more like furtherance of U.S. foreign policy than independent labor solidarity. Though each case brings different historical and political circumstances to bear, the ACILS programs in place in each case at best raises eyebrows, and at worse indicts the Solidarity Center for furthering U.S. foreign policy independent of the AFL-CIO.

In Venezuela, the ACILS was part of a massive increase in "democracy promotion" funds following the election of Hugo Chavez in 1998. These funds were designated for Solidarity Center work with the CTV, who joined with a coalition of rightwing forces to briefly remove the popularly elected president in 2002. Though the ACILS, like the U.S. state, claimed ignorance in regard to the plot to remove Chavez from power, the record indicates that the ACILS support for the CTV was tied into a historical relationship and that this support was at the expense of other labor 
organizations, including Chavista unions. All indications are that the CTV-

FEDEMARCAS alliance was public in its denunciations of the Chavez regime, and furthermore, that the U.S. state had advance warnings of the coup. The statements released by the AFL-CIO following the coup make it clear that the Federation blamed the Chavez regime for the coup, as did the U.S. state, and obscure the role that the Solidarity Center had in promoting the CTV within Venezuela as a legitimate opposition to the Chavez regime. Finally, the ACILS sought to displace any responsibility by arguing repeatedly that it was only involved in a routine promotion of democratic unionism, ignoring all questions by scholars and journalists that questioned why the Solidarity Center was part of the "democracy promotion" offensive in the first place.

In Haiti, the case study identifies that the pre-cursor to the Solidarity Center worked diligently to displace anti-Duvalier and pro-Lavalas labor organizations prior to 2000. Afterwards, surface indications are that the Solidarity Center eschewed working in Haiti, until late 2003 or early 2004 when it partnered with a small radical labor organization: Batay Ouvriye. Rather than working with labor union that supported the popularly elected president of Haiti, the ACILS decided instead to funnel significant amounts of money to a labor organization that was remarkable in its anti-Lavalas and anti-Aristide rhetoric. At a time when labor groups that supported Aristide were persecuted by the post-Aristide regime, the ACILS remained silent.

Finally, as the "war on terror" ramped up following 9/11, the Solidarity Center received millions of dollars in grants for work in the Middle East and North Africa, even though the Center had previously done little work in the region. While the rank and file AFL-CIO membership demanded an end to the occupation, the ACILS obtained large 
amounts of taxpayer dollars for work in Iraq. Furthermore, the ACILS expanded its operations in the MENA region exponentially during the "war on terror" clearly in line with the priorities of the U.S. state and over the opposition of AFL-CIO member unions. In each of these cases, the linkages between Solidarity Center activity and "democracy promotion" programs are apparent. In response, the ACILS has either refused to comment, or has argued that it was working to foster democratic unionism. This obscures the larger picture of Solidarity Center activity, which at least on its face value is intimately tied into U.S. foreign policy goals. Without a full accounting for past practices and an "opening of the books" in regard to current practices, it is difficult if not impossible to reconcile such activities with an independent foreign policy for labor. 


\section{CHAPTER V.}

\section{THE ACILS AND NGO V. STATE POWER}

One of the most discussed topics among scholars of IR as the world enters the $21^{\text {st }}$ century has been whether or not technology and the compression of time and space has eroded the Westphalian system of states and its dominant power source, the state, towards a more diffuse system, led by the growth in NGOs. This debate in essence has been between the hyperglobalization camp, who see a new world order emerging where NGOs are increasingly able to shape policy and wield power on the international stage, and those who for lack of a better term are realists, and believe that states are still the dominant actors in the international system. As a self-proclaimed "NGO", the previous pages detailing the linkages between the Solidarity Center and the U.S. state help shed some light on this debate.

The hyperglobalization view, that states are declining in power and relevance are best described by Mathews, who argues that:

The end of the Cold War has brought no mere adjustment among states but a novel redistribution of power among states, markets, and civil society. National governments are not simply losing autonomy in a globalizing economy. They are sharing powers - including political, social, and security roles at the core of sovereignty - with businesses, with international organizations, and with a multitude of citizens groups, known as nongovernmental organizations (NGOs) (Mathews 1997, 50).

As this passage makes clear, some scholars see the rise of NGOs as containing a threat to the traditional powers of the state and all that it encompassed for the last five centuries. Scholars in the hyperglobalization camp argue that technological changes along with a 
growth in "civil society" are empowering non-state actors in new ways that is changing everything from warfare to poverty alleviation.

Moreover, this alleged shift is generally cited as being part and parcel of the sweeping changes to the international arena following the end of the Cold War. In fact, a significant assumption of much of this scholarship is that the Cold War in effect bottled up the abilities of organizations to act independently. In this worldview, the Cold War was so polarizing that there was little room for maneuverability. Therefore, through this theoretical lens, the activities of the precursor institutions to the Solidarity Center flow logically from the exigencies of the Cold War. Given the division of the world between two superpowers, it should have been expected that organizations like AIFLD would follow the lead of the U.S. state. Alongside U.S. foreign policy that was defined in NSC 68, the AFL and later AFL-CIO thus acted as a junior partner in U.S. efforts to make the world safe for American hegemony.

Further, for scholars like Mathews, it isn't just that NGOs are coopting traditional state powers, it is also that "[i]ncreasingly, NGOs are able to push around even the largest governments" to achieve their aims (Ibid.). Under this view, every bit of power taken by NGOs comes at the expense of the traditional actors who have managed (or mismanaged) global affairs. Often scholars point to the Zapatista uprising in Chiapas, Mexico as evidence of this new power balance. States may be reluctant to use force under the watchful eye of NGOs which can report information at a pace unparalleled in human history. In addition, under the hyperglobalization thesis the explosion of NGOs has also empowered citizens to unite into different interest groups. 
There are many examples used which are often used to bolster the overall claims of hyperglobalization, including the rise of the European Union, the power and widespread legitimacy of groups like Amnesty International, and even more recently the spread of social media as a conduit for sharing information. Mathews puts forth the proposition that although this is not necessarily an entirely new phenomenon, citing the British East India Company, the sheer number of NGOs and their impact is greatly increasing, and that "...a still larger role likely lies ahead" (52).

To a certain degree, in terms of this research, the surface indications are that this is at least part of the story. In looking at the sheer volume of organizations like the ACILS funded by the NED, it is clear that whatever the role of these organizations, they are increasing in number and prominence. According to the NED, it gives out over 1,000 grants a year to wide variety of NGOs that focus on a range of issues including human rights, private enterprise, and transparency promotion, in addition to the ACILS' furtherance of democratic unionism.

However, there is another view that argues the hyperglobalists are missing the larger point. Sending and Neumann (2006) argue that the conception of globalization put forth by scholars like Mathews is faulty as it expresses politics as a zero sum game (652). That is, power is fluid and cannot be quantified on a level as absolute as the hyperglobalists would want us to believe. For Sending and Neumann, the role of the state must be viewed as part of the world in which NGOs operate. Therefore, “...different types of nonstate actors are often funded, actively encouraged and supported by states both to mobilize political constituencies, to confer legitimacy to policy processes, to implement policies, and to monitor and evaluate them" (Ibid.). 
Of course, both of these conceptions of the role of NGOs in the interstate system are fairly rigid. While one argues that NGOs exist outside the realm of states, and still have the power to influence state actions, the other argues that NGOs exist often at the pleasure of states. As is usually the case, other scholars have sought a third interpretation, that NGOs and states cooperate, with NGOs helping gather information and monitor situations at the ground-level (Raustiala 1997), or that although NGOs are powerful, they face limitations depending on the scope of their ambitions and the structural constraints of the system they operate in (Reimann 2006), or that the events following 9/11 indicate NGOs are still subordinate player, as Sunga notes writing that the Bush Administration strong armed NGOs into limiting criticisms of its policies in Iraq (Sunga 2007).

My research indicates that while this is a complex issue, the balance of power still remains with states. In relation to the Solidarity Center and the foreign policy of the U.S. state, David Rieff's interpretation of NGOs being coopted as arms of the state in instances of military intervention rings powerful. Citing the "French Doctors" in Biafra as just the first of many examples, Rieff argues NGOs can still be thought of as “...taking sides, and following their own government's agenda in the process" (Rieff 2010,1). That is, NGOs are rarely if ever "neutral", and must make trade-offs involving their power if they want to receive assistance, or even access to crucial situations. Rieff cites quite a few examples that seem especially true for the ACILS, noting that:

...in late 2001, after the invasion of Afghanistan, then Secretary of State Colin Powell, in a speech to NGO representatives, articulated a view of their role, at least in conflict zones where U.S. forces were fighting and areas where the country had a strong national interest, that were straight out of the civil affairs-oriented counterinsurgency strategy pioneered by 
General Edward Lansdale in the Philippines in the 1950s and Vietnam in the early '60s. The NGOs, Powell said, were a tremendous "force multiplier" for the U.S. military, and, by extending the reach of the U.S. government, would do much to help accomplish the intervention's goals (Ibid.).

For the Solidarity Center, like the other core-grantees of the NED, it seems likely that this is how those who fund their operations often define the power stakes. That is, though the ACILS can operate "independently" in terms of choosing to turn down a grant, with the Solidarity Center receiving over $90 \%$ of its funding via the U.S. state (regardless of whether one accepts the notion that NED funds are somehow "private") we should not be surprised that access is limited for organizations that are seen as counter-productive to U.S. (or other dominant states) geostrategic goals. The research presented in this dissertation largely supports this view of NGOs in the $21^{\text {st }}$ century: independent only as long as they are useful to the state.

This view is explored even further by Sunga, who outlined the difficulties of NGOs operating in Iraq, a highly relevant point for the MENA case study of the Solidarity Center. Accordingly, Sunga detailed the collaboration that occurred between the U.S. state and NGOs before the invasion:

Prior to the commencement of armed hostilities, American based NGOs met with U.S. government officials on several occasions to clarify the extent to which NGOs could operate freely in Iraq...According to NGO representatives who participated in these negotiations, U.S. government officials offered funds to NGOs at this juncture but insisted on the formation of a clear chain of command between U.S. authorities and NGOs - an early bad omen for NGOs intending to work in Iraq (Sunga 2007, 105). 
The relationship between the ACILS as an "NGO" in Iraq is not mentioned specifically by Sunga, however the pattern that emerges from this account continues to indicate that at least in the Iraqi case, NGOs were clearly considered, in Colin Powell's words, a "force multiplier" rather than independent entities. For example, Sunga cites USAID administrators who argued that all NGOs receiving USAID funds had to clear media interactions and publicity events with USAID first, since the Bush Administration believed “...that recipients of federal grants are agents of the US government and its policies" (107). Of course, the counter argument is that the grants examined in this dissertation were funded by the NED, not USAID. However, it seems unlikely that since the original source of funding for both is the U.S. state that the administration would have seen much grey area between these grants and the behavior of the grantees. This is just one example of the ways in which state power conflicts and (possibly) abrogates the initiative of NGOs: the elimination of funding streams.

Other conclusions can also tacitly be broached. For example, the data examining NED funding flows to the Solidarity Center indicates that the ACILS was part of the broad "democracy promotion" offensive waged against the democratically elected government of Hugo Chavez beginning in 1998. In this scenario, it seems unlikely that the U.S. state would in essence force the ACILS to work with the CTV. However, a much more likely scenario is that the grant-writers and liaisons between the ACILS and the NED anticipate what the desirable types of activities are for such activity, and then tailor the specific grants to fall in line with patterns of reliable funding. Thus, the absence of the smoking gun is accounted for, while the outcome still tracks nicely with 
U.S. foreign policy goals. The larger point here is that NGOs such as the ACILS are probably never as independent as they claim, and also not mere "arms of the state".

Importantly, another way of breaking down the debate between the hyperglobalists and the realists, to use the terms most associated with the contrasting positions, is found in how these NGOs are analyzed by scholars. As Reimann notes, depending on whether the analysis starts as a "bottom up" explanation or is viewed from the "top-down", this will determine in some manner the way expectations are drawn and the way research questions are approached. Reimann, in critiquing much of the literature on international NGOs, writes that often the relevant scholarship is focused on either how these NGOs perform in their stated goals, or by analyzing what they purport to do. Thus, the field has inherently limited itself by assuming that NGOs are a response to "...socioeconomic factors, the new information revolution and/or the decline of the state" (Reimann 2006, 45).

Critically, Reimann underlines the importance of the state in creating and maintaining NGOs arguing “...it is impossible to understand the explosive growth of NGOs in the past decade without taking into account the ways in which states, international organizations, and other structures have actively stimulated and promoted NGOs from above" (46). In line with the points raised by Sunga in the case study of Iraq, Reimann points out that two key variables are apparent in the rise of NGO growth "resources in the form of grants, contracts, and other kinds of institutional support... and... political access to decision-making bodies and agenda setting arenas" (48). Reimann's insights into the "top down" view of NGO growth is most succinctly expressed when he writes that “...[g]iven the billions of dollars of international funding 
now available to NGOs in all corners of the globe, it would have been more surprising if there had been no explosive growth of NGOs in the 1980s and 1990s" (63).

Perhaps most importantly, recent work by Stroup (2012) indicates that these patterns are becoming the norm in regard to what she terms "international NGOs" or "INGOs", which “... are increasingly active in international arenas...” while “... actual organizational structures and strategies are deeply tied to national environments" (3). The research in this dissertation fit nicely within Stroup's analysis, as the Solidarity Center is an excellent example of an international actor that seems to be largely reliant on domestic U.S. state support for both funding and direction.

Thus, the work of Reimann (2006), Sunga (2007) and Stroup (2012) in particular are of crucial importance in considering the larger significance of this case study. For example, as I argue in chapter three, many scholars and activists looked to the creation of the ACILS as a product of a new group of labor leaders responding to the Cold War era criticisms of AFL-CIO foreign policy. That is, for some, the AFL-CIO was responding to pressure from below in consolidating the four regional institutes into a single center. Part of this stemmed from the fact that the "New Voices" slate won the first ever truly democratic election AFL-CIO history, in contrast to the past where power had been handed from one regime to the next through a system that looked more like patronage than democratic transparency. Added to this was the fact that so many of the "New Voices" leadership had been vocal leaders in the National Labor Committee in Support of Democracy and Human Rights in El Salvador, a group of mid-level labor leaders who had openly criticized U.S. (and by default) AFL-CIO policy in El Salvador in the 1980s. Therefore, after decades of agitation by dedicated rank and file members for the 
leadership to "open the books" it seemed that a serious shift in the Federation was occurring. For activists, this change was often viewed with a cautious optimism that the Federation was evolving towards a more open and transparent organization, even in the usually closed circuit of foreign policy.

However, my research indicates that in this matter the dominant thinking may have the causal arrow pointed in the wrong direction. That is, in fact the positive response to the creation of the Solidarity Center might have been based upon assuming the "bottoms up" approach rather than the "top down" analysis that Reimann describes. If the GAO report analyzed in chapter three is correct, the AFL-CIO was not responding to pressure from below, but rather structural demands from above. The GAO report, which I have failed to see analyzed elsewhere, is explicit in this regard, stating that "[i]n response to decreasing funds, USAID is encouraging the AFL-CIO to consolidate its regional institutes into a new single global institute..." (GAO 1996). Within a year of this report, the AFL-CIO had done just that, creating the Solidarity Center in 1997.

Partly the problem stems from optimism among labor activists and scholars, although it should be noted that many were wary of the authenticity of these changes. But by reading between the lines it is clear that the creation of the Solidarity Center was a cosmetic change, implemented in the name of efficiency, rather than transparency; coercion rather than reflection. This is in keeping with the Federation's refusal to account for past practices even after the ACILS was created. At no point did the AFLCIO leadership discuss the foreign policy during the Cold War with its members, nor how the path moving forward would be qualitatively different from the past. 
Therefore, if the ACILS was created due to pressure from USAID, an arm of the U.S. state and a primary funding source for both the regional institutes during the Cold War and the Solidarity Center thereafter, it should not be surprising to see a continuation in previous patterns of foreign policy. Examining the Solidarity Center as an NGO with the top down approach, the activities of the ACILS and their linkages with U.S. foreign policy begin to make much more sense.

Therefore, the research documented in this work indicates that the Solidarity Center is much more a creation and creature of the U.S. state than the ACILS publicly avows. On balance, the central proposition of this work, that the activities of the Solidarity Center can best be explained by its relationship with the U.S. state, is illuminated by examining the balance of the evidence presented in the previous pages. The data indicates that the Solidarity Center is following U.S. state funding in its operations, is overwhelmingly dependent on funding via from the U.S. state, and finally, working closely with allies and coalitions of the U.S. state in its work overseas.

The central proposition my dissertation has sought to examine is whether the foreign policy of the American Center for International Labor Solidarity is best explained by its relationship with the U.S. state. The creation of the Solidarity Center was portrayed as a break with what were widely criticized by scholars and labor activists as the activities of the "AFL-CIA" during the Cold War. However, though many claims have been made by the ACILS since the consolidation of the four regional institutes into the Solidarity Center in 1997, significant evidence in this dissertation has linked the role of the AFL-CIO abroad to the exigencies of the U.S. state. Examining the relevant scholarship, it is clear that the four foreign policy institutes which carried out AFL-CIO 
foreign policy prior to the ACILS worked with the U.S. state to stabilize friendly regimes and to destabilize those governments which ran afoul of U.S. geostrategic interests during the Cold War.

The four foreign institutes worked to stabilize authoritarian and non-democratic regimes in El Salvador, Nicaragua, the Philippines, South Korea, Grenada, Haiti, South Africa, Russia under Yeltsin, and Brazil after the military coup of 1964 during this time period. Conversely, in Guatemala, British Guiana, Brazil, and Chile the institutes worked to undermine regimes that were targeted for destabilization by Washington. As the list indicates, the institutes often engaged in both tactics in the same country at different times indicating that the AFL-CIO was more attuned to U.S. foreign policy goals than to strict principles. For example, AIFLD played a vital role in both destabilizing Brazil in 1964, and then working to bolster the military regime that followed.

In addition, I argue that a key turning point in understanding U.S. foreign policy as well as AFL-CIO foreign policy occurred in the early 1980s with the creation of the National Endowment for Democracy (NED). The NED became a vehicle for implementing U.S. foreign policy through less overt means, or as Allen Weinstein, one of the founders of the NED famously quipped: "[a] lot of what we do today was done covertly 25 years ago by the CIA" (Ignatius 1991). Drawing on the work of scholars like William I. Robinson (1996) and Nicolas Guilhot (2005), the role of the AFL-CIO as the one of the four "core" grantees of the NED was explored in relationship to implementing "limited" democracy in the developing world as a more efficient and less costly way of manipulating outcomes in contrast to supporting authoritarian or dictatorial regimes. In addition, this line of inquiry supports a theory of NGOs more in line with realist 
assumptions than the hyperglobalization theory allows. Looking at the evidence, the surface indications of the relationship between the U.S. state, NED, and ACILS make this even clearer.

Examining patterns of funding flows that sustain ACILS projects around the globe demonstrate linkages between U.S. foreign policy goals and the activities of the Solidarity Center. Given the lack of information provided by the ACILS (it only reports aggregate funding of the center as a whole without detailing where each grant originates or how much is spent on each project) a combination of publicly available NED Annual Reports data was combined with the aggregate funding information put out by the ACILS to determine how much funding for the Solidarity Center originated from the NED and what projects were funded. This data indicates a striking correlation between U.S. foreign policy goals and the activities of the Solidarity Center abroad. In countries and regions of specific U.S. geostrategic importance the funding flows for the ACILS via the NED spiked repeatedly. In addition, a steady increase in percentages of funding for the ACILS via the NED was noted, as by 2008 and 2009 the NED was roughly accounting for half of all the grants supplied to the Solidarity Center.

In Eastern Europe the data indicates a significant spike in funding for the Balkan region from 2001-2006, where the U.S. and NATO were working to oust Slobodan Milosevic. Particularly, there was significant funding of the anti-Milosevic UGS Nezavisnost, a labor organization that both wanted regime change in Yugoslavia and greater integration into the neoliberal world economy. This spike in funding for work with labor organizations in the Balkans petered out and disappeared in 2006, by which 
time U.S. foreign policy goals in the region had been mostly accomplished with the removal of Milosevic and the integration of these states into the global economy.

In Eurasia significant jumps in funding seemed to mirror U.S. interests in the region. Funding spiked around the Russian elections of 2008 as well as in the key oil and natural gas states of Georgia, Kyrgyzstan, Kazakhstan, and Uzbekistan after 2003. This region, as noted by Stokes and Rafael (2010) was targeted for significant military and intelligence activity by the U.S. state as China, Russia, and the U.S. vied to securitize their oil and natural gas reserves. Again, the flurry of ACILS activity in the region seems to be correlated with U.S. geostrategic interests as opposed to labor solidarity.

In the Middle East and North Africa (the "MENA" region), Solidarity Center funding flowing from the NED closely tracks the increase in strategic importance for the region following the "war on terror." Prior to the 2003 invasion and occupation of Iraq the ACILS had but one NED funded program in the Middle East, yet by 2005 the Solidarity Center had organized two regional offices (one in Amman, Jordan, the other in Algiers, Algeria) and begun several programs all over the MENA region using millions of dollars in NED grants. Again, this correlation seems to speak to the degree to which the ACILS is following the lead of the U.S. state in geostrategic "hot spots".

Finally, in Latin America the Solidarity Center saw significant jumps in NED funding following on the heels of the election of Hugo Chavez in 1998, and a general increase for the Andean region that roughly correlates with the election of a slate of populist and leftist leaders in Venezuela, Bolivia, and Ecuador. Also of particular interest was the removal of NED funding specifically for Venezuela after the 2002 coup, but an increase in funding for Colombia and "regional" Andean grants, which do not provide 
much in the way of specifics. The rough contours indicate that in Latin America the ACILS was responding to an upsurge in popular democracy that opposed the moderate, pro-U.S. leadership that had dominated the region previously.

The broad contours of this data indicate that the view of NGOs such as the Solidarity Center, and likely the other three "core grantees" is much more in line with descriptions of "top-down" NGO growth as opposed to "grassroots" organizations responding to popular demands. Moreover, in relation to the first two parts of the central proposition addressed in chapter one, it seems clear that the Solidarity Center is closely following U.S. funding and is overwhelmingly dependent on grants from the U.S. state for its operations.

Though these statistics are quite striking on their own, I also examined three dissimilar case studies to examine the details of the NED-ACILS relationship in the larger context of "democracy promotion" programs. The central concern here was analyzing whether the Solidarity Center is aligning with U.S. allies and coalitions in their operations overseas. In Venezuela, the Solidarity Center was part of a massive increase in "democracy promotion" funding following the election of Hugo Chavez in 1998. In this case study I detailed how the rise of Chavez was related to the crumbling of "pacted democracy" in Venezuela. The Punto Fijo pact and the following forty years of stability in Venezuela mirrored the type of "democracy promotion" that the NED began to promote in the 1980s. Though the 1998 election resulted in the largest electoral victory for a candidate in forty years, the response by the NED was to warn of "imperiled" democracy in Venezuela and boost funding for its programs immediately. The Solidarity Center was a major recipient of these funds, and partnered with the CTV, a labor 
organization it had worked with during the 1980s to combat leftist labor influences in the region, that coincidentally had aligned itself with FEDECAMARAS, the Venezuelan business opposition to Hugo Chavez. The CTV was later involved with the brief coup that removed Hugo Chavez from power. In response the ACILS argued that this was merely a coincidence. However, the repeated denials from the Solidarity Center focused merely on their innocence in complicity with the coup leaders and ignored larger questions regarding ACILS involvement in Venezuela in the first place. Shortly thereafter, the ACILS moved its Venezuela operations to Colombia.

The case study of Haiti detailed the involvement of the precursor to the Solidarity Center, AIFLD, in the Caribbean nation dating back to the mid-1980s, when AIFLD worked to set up the Federation of Trade Union Workers with the blessing of Baby Doc Duvalier, in order for Haiti to qualify for the Caribbean Basin Initiative. AIFLD ignored existing labor organizations that were opposed to the Duvalier dictatorship and instead focused on creating an apolitical business union in line with the strategic partnership between Duvalier and the U.S. state. After the fall of the Duvalier, AIFLD and other NED grantees funneled large amounts of money to conservative candidates in an effort to undermine Haiti's most popular candidate for the presidency, Jean Bertrand-Aristide and his Lavalas movement. Following Aristide's re-election in 2000, the Solidarity Center eschewed working with labor organizations in the country as the U.S. and France led a virtual embargo on the impoverished nation. Then, sometime in 2003 or 2004, the ACILS partnered with a radical anti-Aristide labor organization, and when Aristide was ousted for a second time remained silent as Lavalas aligned labor organizations were persecuted by the Haitian regime. In addition, this case study indicated troubling 
similarities with the Venezuela case study, as in both instances the U.S. state argued that the popularly elected leaders themselves were to blame for their removal, and the AFLCIO either agreed openly or remained strangely silent on the matter.

Finally, I examined Solidarity Center activity in the MENA region, particularly Iraq and Egypt. This case study indicated the disconnect between the AFL-CIO rank and file and the projects of the Solidarity Center. At a time when AFL-CIO membership was organizing at the grassroots level to end the occupation of Iraq, and in the face of a conflicted leadership over the war in general, the ACILS accepted the largest grants in the period under review for work in occupied Iraq. In addition, the Solidarity Center clearly followed the lead of the U.S. state, beginning work in a variety of countries that made up fronts in the "war on terror" and set up two regional offices for its "democracy promotion" programs.

Though none of these activities can be construed as a "smoking gun", the patterns of correlation leave little doubt that Solidarity Center programs follow the lead of the U.S. state. Furthermore, there is significant support for the proposition that the ACILS is partnering with organizations allied with U.S. interests. In Venezuela, Haiti, and the MENA region the Solidarity Center operations seem to line up more with political considerations than with specific principles.

Therefore, when we examine the foreign policy of the AFL-CIO during the Cold War, under the lens of anti-communism and U.S. protection for client regimes and destabilizing campaigns for "rogue" regimes, it becomes clear that the exigencies of the US state are easily the best indicator of AFL-CIO foreign policy prior to the creation of the Solidarity Center in 1997. The creation of the Solidarity Center was supposed to 
embody a break with these past practices. However, my research reflects an understanding of a shift in US foreign policy in the 1980s via NGO promoting organizations like the NED. This shift in foreign policy from communist containment and making the world safe for capitalism to one of "democracy promotion" with the end goal of promoting polyarchic regimes in the developing world has become the dominant

goal of U.S. policy in the post-Cold War era. Viewed through this theoretical framework, the activities of the Solidarity Center become much clearer. Rather than a string of unrelated "fires being put out" across the globe in the name of organized labor, we see the ACILS following the US state, both in accepting the vast majority of its funding from the NED and other democracy promoting organizations, as well as the projects it chooses to undertake.

\section{CONCLUSION}

Without theories, political phenomena are trapped in a world of unrelated accidents. Events become meaningless in relation to one another and the difficult process of obtaining meaning and direction behind occurrences becomes impossible. In this regard, the activities of the Solidarity Center, specifically its foreign policy, viewed without a theoretical framework, becomes just a series of grants and activities to aid a tremendous range of labor organizations in different regions of the world under widely varying conditions. Indeed, this is in large part the story told by the Solidarity Center when questioned regarding its activities abroad. The Solidarity Center, by refusing to open the books or discuss the details of its operations intends for the narrative regarding their existence to be defined by valiant battles fought for no other reason than to secure 
labor democratization and labor rights for the worlds oppressed. Reading the sparse statements regarding their activities in places like Venezuela, Iraq, Haiti, it is clear that the ACILS wants to paint a picture of a mission statement that it operates without constraints and is completely independent of control by the U.S. state.

Most importantly, it is not the goal of this dissertation to ascribe intent to the ACILS for these activities. Numerous explanations could lessen the culpability of ACILS staff, including arguments concerning the inherent inertia of bureaucracies seeking funding sources. However, it is the intent of this dissertation to show how the activities of the ACILS make much more sense when viewed through the lens of US foreign policy priorities.

Though the world has changed quite a bit since the end of the Cold War, the AFLCIO is still following the US state to a significant degree. This work does not also claim to explain all ACILS activity. During the course of this research it became clear that in many locations (usually with much less funding) the ACILS has done tremendous work. As discussed in chapter three, the ACILS has partnered with human rights and student anti-sweatshop organizations in its work in China, a laudable effort to protect some of the most exploited workers today. However, while the independent works of the ACILS need more research, the activities which follow the US state likely need more oversight.

The activities of the Solidarity Center should be viewed in its proper context. That is, as long as it remains reliant on the U.S. state for funding, we should not be surprised to see the Solidarity Center following the lead of the state in working to implement U.S. foreign policy in its actions abroad regardless of its statements to the contrary. Though the Solidarity Center is a more sophisticated organization than its 
predecessors, it has merely substituted the machinery of democracy promotion in the place of covert actions, as did the U.S. state in the 1980s. The larger question of whether the ACILS could, or would exist if it were not for the U.S. state is an important corollary to this view, as given the state of the labor movement in the United States today, it seems unlikely that such an organization could exist on its own accord. Therefore, in the same manner that the "democracy promotion" activities of the ACILS often give labor organizations in the developing world a legitimacy that may outsize their own resources, in many ways the backing of the U.S. state gives the AFL-CIO the same legitimacy when it operates overseas, regardless of its authenticity.

The seeds of change in regard to Solidarity Center policies are already extant: the rank-and-file membership of the AFL-CIO remains the only real catalyst for the changes that many hoped the creation of the ACILS would entail. Although the previous discussion often referred to the Federation as a unified bloc, in fact the AFL-CIO's internal dynamics will largely shape alternative visions for Solidarity Center activity moving forward. Within the AFL-CIO, numerous unions have demanded, and continue to demand, a full accounting of past and present practices by the Federation abroad. As the American labor movement increasingly relies on public-sector unions as its privatesector numbers shrink, there remains hope that the practices detailed in this work will be further brought into the light and that a new version of labor internationalism will emerge in-line with the shifting demographics of the Federation. Given the increasing complexity of global capitalism, with value-chains and manufacturing processes spread around the globe, the labor movement needs more focus on issues specific to the working class rather than to U.S. foreign policy. At home, there are early indications that the 
AFL-CIO is beginning to respond to increasing income and political inequality among the working class, and hopefully Federation membership will remember that part of the solution to these structural inequalities is found in true solidarity with the working class worldwide. 


\section{LIST OF REFERENCES}

Advisory Committee on Labor Diplomacy. 2001. "Labor Diplomacy: In the Service of Democracy and Security." Advisory Committee on Labor Diplomacy Report, 31 December. http://www.state.gov/j/drl/rls/10043.htm (September 27, 2012).

African American Labor Center (AALC) Reporter. 1974. "AALC Policy Statement." (August-September).

Agee, Phillip. 1975. Inside the Company: CIA Diary. London: Penguin Press.

Ancel, Judy. 2000. “On Building an International Solidarity Movement.” KC Labor, 1 February. http://www.kclabor.org/ancelresponsesipes.htm (September 27, 2012).

Andrews, Gregg. 1991. Shoulder to Shoulder?: The American Federation of Labor, the United States, and the Mexican Revolution, 1910-1924. Berkley: University of California Press.

Askin, Steve and Barbara Yuill. 1985. "AFL-CIO Angers South Africans.” In These Times, 23 January.

Aviles, William. 2012. "The Political Economy of Low-Intensity Democracy.” In Corporate Power and Globalization in US Foreign Policy, ed. Ronald W. Cox. New York: Routledge Press.

Babcock, Robert H. 1974. Gompers in Canada: A Study in American Continentalism before the First World War. Toronto: University of Toronto Press.

Barker, Michael. 2011. "Reporting on Egyptian Workers: Solidarity in the Name of Capitalism." Swans, 28 March. http://www.swans.com/library/art17/barker75.html (September 27, 2012).

Batay Ouvriye. 2005a. "Response to Slander at the 'Haiti International Tribunal': New Heights Attained by the Haiti-Progress Current and Its Allies." 1 October. http://www.batayouvriye.org/English/Positions 1/responseithp.html (September 27, 2012).

- 2005b. "Clarification." 16 December. http://www.batayouvriye.org/English/Positions1/clarificationithp.html (September 27, 2012). 
- 2008. "One Last Note Concerning the Solidarity Center." October. http://www.batayouvriye.org/English/Positions 1/solcenterlastnote.html (September 27, 2012).

Beard, Avri. 2004. "Neoliberalism and Democratization: Why Oligarchs Support Elections." Presented at the Annual Meeting of the American Sociological Association, San Francisco.

Berger, Henry W. 1967. “American Labor Overseas.” The Nation, 16 January.

- 1969. "Labor and State: Marriage of Convenience." The Nation, 13 January.

Black, Jan Knippers. 1977. United States Penetration of Brazil. Philadephia: University of Pennsylvania Press.

Bogdanich, Walt and Jenny Nordberg. 2006. "Mixed U.S. Signals Help Tilt Haiti Toward Chaos." The New York Times, 29 January.

Boodhoo, Ken I. 1986. "The Grenada Revolution: Rationale for Failure and Lessons for the Caribbean (Dialogue \#61)." LACC Occasional papers series. Dialogues (1980 1994). Paper 8. http://digitalcommons.fiu.edu/laccopsd/8 (September 25, 2012).

Bolton, K. R. 2011. "Is Egypt's Labor Movement Being Co-opted By Globalists?" Global Research, 21 February. http://www.globalresearch.ca/is-egypt-s-labormovement-being-co-opted-by-globalists/ (September 27, 2012).

Braden, Thomas W. 1967. "I'm Glad the CIA is Immoral." The Saturday Evening Post, 20 May.

Buhle, Paul. 1999. Taking Care of Business: Samuel Gompers, George Meany, Lane Kirkland, and the Tragedy of American Labor. New York: Monthly Review Press.

Cantor, Daniel and Juliet Schor. 1988. Tunnel Vision: Labor, the World Economy, and Central America. Boston: South End Press.

Carew, Andrew. 1998. "The American Labor Movement in Fizzland: The Free Trade Union Committee and the CIA." Labor History 39(1): 25-32.

Carothers, Thomas. 1994. “The NED at 10.” Foreign Policy 95(Summer): 123-38.

Castaneda, Jorge. 2004. “US, Spain supported anti Chavez 2002 coup.” MercoPress, 27 November. http://en.mercopress.com/2004/11/27/us-spain-supported-anti-chavez2002-coup (September 25, 2012). 
Charnovitz, Steve. 1984. "Caribbean Basin Initiative: Setting Labor Standards.” Monthly Labor Review (November): 54-56.

Ciment, James and Immanuel Ness. 1999. "The National Endowment for Democracy and the Empire's New Clothes." Covert Action Quarterly, 8 September. http://www.thirdworldtraveler.com/NED/NED-EmpiresNewClothes.html (September 25, 2012).

Clement, Christopher I. 2005. "Confronting Hugo Chavez: United States 'Democracy Promotion' in Latin America.” Latin American Perspectives 32(3) (May): 60-78.

Cohen, Barry. 1979. "The CIA and African Trade Unions." In Dirty Work 2: The CIA in Africa, eds. Ellen Ray, et. al. London: Zed Press.

Collier, Robert. 2004. “Old Relationships Die Hard: A Response to Stanley Gacek's Defense of the AFL-CIO's Position on Venezuela." New Labor Forum 13(2): 93-99.

Conry, Barbara. 1993. CATO Foreign Policy Briefing No. 27. "Loose Cannon: The National Endowment for Democracy." CATO Institute, 8 November 8. http://www.google.com/search?client=safari\&rls $=$ en\&q $=\% 22$ loose+cannon: + the + na tional+endowment+for + democracy $\% 22 \&$ ie $=$ UTF-8\&oe $=$ UTF-8 $($ September 25, 2012).

Cox, Ronald. W., and G. Nelson Bass. 2012. "The Foreign Policy of Organized Labor in the Context of Globalization." In Corporate Power and Globalization in US Foreign Policy, ed. Ronald W. Cox. New York: Routledge Press.

Daum, Walter. "Exchange between LRP and Batay Ouvriye." League for the Revolutionary Party. http://www.lrp-cofi.org/statements/bo exchange.html (September 25, 2012).

Deere, Carmen Diana. 1982. "A Comparative Analysis of Agrarian Reform in El Salvador and Nicaragua 1979-81." Development and Change 13(1): 1-41.

Ellner, Steve. 2005a. "The Emergence of a New Trade Unionism in Venezuela with Vestiges of the Past." Latin American Perspectives 32(2): 51-71.

- 2005b. “The Venezuelan Labor Movement Under Chávez: Autonomous Branch of Civil Society or Instrument of Political Control?" A Contra Corriente 2(3): $102-25$.

- 2008. Rethinking Venezuelan Politics. Boulder: Lynne Rienner Press.

Ferguson, Thomas, and Joel Rogers. 1986. Right Turn: The Decline of the Democrats and the Future of American Politics. New York: Hill and Wang. 
Fillipelli, Ronald L. 1989. Labor and Postwar Italy, 1945-1935: A Study of Cold War Politics. Stanford: Stanford University Press.

Fletcher Jr., Bill, 2005. “Globalization, Labor, and Justice.” WorkingUSA 8(3): 259-269.

Fordham, Benjamin. 1997. "Domestic Politics, International Pressure, and Policy Change: The Case of NSC 68." Journal of Conflict Studies 17(1).

Forero, Juan. 2004. "Documents Show C.I.A. Knew of a Coup Plot in Venezuela." The New York Times, 3 December.

Frundt, Henry J. 1995. "AIFLD in Guatemala: End or beginning of a New Regional Strategy?" Social and Economic Studies 44(2/3): 287-319.

Gacek, Stan. 2005. "A Rejoinder to 'Revolution and Counter-Revolution'." New Labor Forum 14(3): 109-114.

George, Alexander, and Andrew Bennett. 2005. Case Studies and Theory Development in the Social Sciences. Cambridge: The MIT Press.

Godfried, Nathan. 1987. "Spreading American Corporatism: Trade Union Education for Third World Labour." Review of African Political Economy 14(39): 51-63.

Goldfield, Michael. 1987. The Decline of Organized Labor in the United States. Chicago: University of Chicago Press.

Golinger, Eva. 2004. "The Adaptable U.S. Intervention Machine in Venezuela." Venezuelan Communication and Information Ministry, November. http://www.williambowles.info/venezuela/2005/050318 Golinger_file.pdf (September 25, 2012).

- 2006. The Chavez Code: Cracking U.S. Intervention in Venezuela. Northampton Olive Branch Press.

Gribbin, Peter. 1979. "Brazil and CIA.” CounterSpy (April-May): 4-23.

Griffin, Thomas M. 2004. "Haiti Human Rights Investigation: November 11-21, 2004." The Center For The Study Of Human Rights, University of Miami School Of Law. http://www.ijdh.org/CSHRhaitireport.pdf (September 25, 2012).

Guilhot, Nicolas. 2005. The Democracy Makers: Human Rights and International Order. New York: Columbia University Press.

Hallward, Peter. 2006. "Voting for Hope: Elections in Haiti." Radical Philosophy 138(July/August): 2-8. 
Herod, Andrew. 2001. Labor Geographies: Workers and the Landscapes of Capitalism. New York: The Guilford Press.

Hirsch, Fred. 1974. An Analysis of Our AFL-CIO Role in Latin America: Or Under the Covers with the CIA. San Jose: F. Hirsch.

Hirsch, Fred and Virginia Muir. 1987. "A Plumber Gets Curious About Exporting McCarthyism." In The Cold War Against Labor, Vol. 2, eds. Ann Fagan Giner and David Cristiano. Berkley: Meiklejohn Civil Liberties Institute.

Hoxie, Robert F. 1917. Trade Unionism in the United States. New York: D. Appleton and Company.

Hoyt, Katherine. 2002. "Concerns Over possible AFL-CIO Involvement in Venezuela Coup Led to February Picket.” Labor Notes, 1 May. http://labornotes.org/node/1124 (September 27, 2012).

Ignatius, David. 1991. "Innocence Abroad: The New World of Spyless Coups." The Washington Post, 22 September.

Jordan, James. 2012. “USAID Grants \$3 Million to Solidarity Center’s Bogota Office Unionists Want to Know Why." The Alliance for Global Justice. http://afgj.org/usaid-grants-3-million-to-solidarity-centers-bogota-office-unionistswant-to-know-why (September 27, 2012).

Kurzman, Dan. 1966. "Lovestone's Cold War: The AFL-CIO Has Its Own CIA." New Republic, 25 June.

Lens, Sidney. 1965. “American Labor Abroad: Lovestone Diplomacy.” The Nation, 5 July.

Luhan, Michael. 1986. “AIFLD's Salvadorean Labor Wars: A Painful Record of Political Arm Twisting.” Dissent 33(3): 340-350.

MacDonald, Isabel. 2005. "The UN's Cleansing of Bel Air Ahead of the Elections." Haiti Information Project, 17 December 17.

http://www.haitiaction.net/News/HIP/12_17 5/12_17_5.html (September 25, 2012).

Marquis, Christopher. 2002. "U.S. Bankrolling Is Under Scrutiny for Ties to Chávez Ouster." The New York Times, 25 April.

Massey, Douglas S. 2009. "Globalization and Inequality: Explaining American Exceptionalism.” European Sociological Review 25(1): 9-23.

Mathews, Jessica. 1997. "Power Shift." Foreign Affairs 76(1): 50-66. 
Meisler, Stanley. 1969. "New Mission To Africa." The Nation, 13 January.

- 1964. "The Dubious Role of AFL-CIO Meddling in Latin Americas." The Nation, 10 February.

Metayer, Guy. 2012. "The Influence of Corporate Interests on USAID's Development Agenda: The Case of Haiti." Ph.D. diss. Florida International University.

Moody, Kim. 2007. US Labor in Trouble and Transition. New York: Verso Press.

Morris, George. 1967. CIA and American Labor: The Subversion of the AFL-CIO's Foreign Policy. New York: International Publishers.

Mort, Jo-Ann, ed. 1999. Not Your Father's Union Movement: Inside the AFL-CIO. New York: Verso Press.

National Democratic Institute of International Affairs. 1991. "The 1990 General Elections in Haiti." The Carter Center. http://www.cartercenter.org/documents/electionreports/democracy/FinalReportHaiti 1990.pdf (September 25, 2012).

National Endowment for Democracy. 1998. Annual Reports. National Endowment for Democracy. http://www.ned.org/docs/annual/1998AnnualReport.pdf (September 27, 2012).

- 1999. Annual Reports. National Endowment for Democracy. http://www.ned.org/docs/annual/1999AnnualReport.pdf (September 27, 2012).

- 2000. Annual Reports. National Endowment for Democracy. http://www.ned.org/docs/annual/2000AnnualReport.pdf (September 27, 2012).

- 2001. Annual Reports. National Endowment for Democracy. http://www.ned.org/docs/annual/2001AnnualReport.pdf (September 27, 2012).

- 2002. Annual Reports. National Endowment for Democracy. http://www.ned.org/docs/annual/2002AnnualReport.pdf (September 27, 2012).

- 2003a. Annual Reports. National Endowment for Democracy. http://www.ned.org/docs/annual/2003AnnualReport.pdf (September 27, 2012).

- 2003b. "Statement of Principles and Objectives." National Endowment for Democracy.

http://web.archive.org/web/20031212193235/http://www.ned.org/about/principles Objectives.html (September 25, 2012). 
- 2004. Annual Reports. National Endowment for Democracy. http://www.ned.org/docs/annual/2004AnnualReport.pdf (September 27, 2012).

- 2005. Annual Reports. National Endowment for Democracy. http://www.ned.org/publications/annual-reports/2005-annual-report (September 27, 2012).

- 2006. Annual Reports. National Endowment for Democracy. http://www.ned.org/publications/annual-reports/2006-annual-report (September 27, 2012).

- 2007. Annual Reports. National Endowment for Democracy. http://www.ned.org/publications/annual-reports/2007-annual-report (September 27, 2012).

- 2008. Annual Reports. National Endowment for Democracy. http://www.ned.org/publications/annual-reports/2008-annual-report (September 27, 2012).

- 2009. Annual Reports. National Endowment for Democracy. http://www.ned.org/publications/annual-reports/2009-annual-report (September 27, 2012).

- 2010. Annual Reports. National Endowment for Democracy. http://www.ned.org/publications/annual-reports/2010-annual-report (September 27, 2012).

National Security Council. 1950. United States Objectives and Programs for National Security.

http://www.trumanlibrary.org/whistlestop/study collections/coldwar/documents/pdf/ 10-1.pdf (September 27, 2012).

Norden, Deborah L. 1998. "Democracy and Military Control in Venezuela: From Subordination to Insurrection." Latin American Research Review 33(2): 143-165.

Peace and Crises Management Foundation. 2012. "Program of Actions in the Transitional Period." 2 June. http://www.fondmir.com/OLDversion/knjige/platforma e.html (September 27, 2012).

Quan, Katie. 2008. "Use of global Value Chains by Labor Organizers." Competition \& Change 12(1): 89-104.

Rabe, Stephen G. 2005. U.S. Intervention in British Guiana: a Cold War Story. Chapel Hill: University of North Carolina Press. 
Raustiala, Kal. 1997. "States, NGOs, and International Environmental Institutions." International Studies Quarterly 41: 719-740.

Rayback, Joseph G. 1959. A History of American Labor. New York: The Free Press.

Reding, Andrew. 1996. "Haiti: An Agenda for Democracy." World Policy Institute. February.

Reed, Louis. 1930. The Labor Philosophy of Samuel Gompers. Ann Arbor: University of Michigan Press.

Reimann, Kim D. 2006. "A View from the Top: International Politics, Norms and the Worldwide Growth of NGOs." International Studies Quarterly 50: 45-67.

Rieff, David. 2010. "How NGOs Became Pawns in the War on Terrorism." The New Republic, 3 August. http://www.tnr.com/blog/foreign-policy/76752/war-terrorismngo-perversion\# (September 27, 2012).

Rivera, Carlos Ala Santiago. 1991. "Labor Relations During the Sandinista Government." Caribbean Studies 24(3/4): 241-265.

Roberts, Kenneth M. 2003. "Social Correlates of Party System Demise and Populist Resurgence in Venezuela." Latin American Politics and Society 45(3): 35-57.

Robinson, William I. 1996. Promoting Polyarchy. Cambridge: Cambridge University Press.

- 2004. "What to Expect from US 'Democracy Promotion' in Iraq." New Political Science 26(3): 441-8.

- 2006. "Promoting Polyarchy: the New U.S. Political Intervention in Latin America." America Latina en Moviemiento, 17 February. http://alainet.org/active/10626\&lang=es (September 27, 2012).

- 2007. "Transformative Possibilities in Latin America." Orfalea Center for Global and International Studies, 1 July. http://escholarship.org/uc/item/64s0f9j0 (September 25, 2012).

Rodberg, Simon. 2001. "The CIO Without the CIA: Inside the AFL-CIO's Solidarity Center." American Prospect (Summer Issue).

Romualdi, Serafino. 1967. Presidents and Peons: Recollections of a Labor Ambassador in Latin America. New York: Funk and Wagnals. 
Schmidt, Hans R. 1995. The United States Occupation of Haiti, 1915-1934. New Brunswick: Rutgers University Press.

Scipes, Kim. 1998. "CIA, AFL-CIO, and Pinochet." Forum on Labor in the Global Economy, 28 December. http://www.hartford-hwp.com/archives/42a/126.html (September 27, 2012).

- 2000. "It's Time to Come Clean: Open the AFL-CIO Archives on International Labor Operations." Labor Studies Journal 25(2): 4-25.

- 2004. "AFL-CIO Refuses to 'Clear the Air' on Foreign Policy, Operations." Labor Notes, 1 February. http://labornotes.org/node/957 (September 27, 2012).

- 2005a. "Labor's Foreign Policy Under John Sweeney: Are 'Missteps' Aberrations--or Return to 'Traditional' Labor Imperialism?" Presented at the Annual Meeting of the American Sociological Association, San Francisco.

- 2005b. "Head of AFL-CIO International Affairs Department Refuses to be on Amy Goodman's 'Democracy Now' Program with Labor Activists Kim Scipes and Fred Hirsch." Chicago Independent Media Center. http://chicago.indymedia.org/newswire/display/60815/index.php (September 25, 2012).

- 2010. AFL-CIO's Secret War Against Developing Country Workers: Solidarity or Sabotage? Lexington: Lexington Books.

- 2012. "Globalization from Below: Labor Activists Challenging the AFL CIO Foreign Policy Program." Critical Sociology 38(2): 303-23.

Scipes, Kim and Fred Hirsch. 2005. "Unholy Alliance? The AFL-CIO and the National Endowment for Democracy in Venezuela." By Amy Goodman. Democracy Now! 26 July. http://www.democracynow.org/2005/7/26/unholy_alliance the_afl_cio_and (September 25, 2012).

Sears, John Bennett. 2010. "Peace Work: The Antiwar Tradition in American Labor from the Cold War to the Iraq War." Diplomatic History 34(4): 699-720.

Sending, Ole Jacob, and Iver B. Neumann. 2006. "Governance to Governmentality: Analyzing NGOs, States, and Power." International Studies Quarterly 50(3): 651672.

Shamsie, Yasmine. 2004. "Building 'Low-Intensity' Democracy in Haiti: The OAS Contribution." Third World Quarterly 25(6): 1097-1115.

Shorrock, Tim. 2002. "AFL-CIO Statement on Worker Rights in Venezuela." 26 April. http://mailman.lbo-talk.org/2002/2002-April/010675.html (September 25, 2012). 
- 2003. "Labor's Cold War." The Nation, 19 May.

- 2005. "Labors Foreign Policy Heads in a New Direction." Foreign Policy in Focus, 11 August. http://www.fpif.org/articles/labors foreign policy heads in a new direction (September 25, 2012).

Shorrock, Tim, and Kathy Selvaggio. 1986. "Which Side Are You On, AAFLI?" The Nation, 15 February.

Siegelbaum, Lewis H., and Daniel Walkowitz. 1992. "The A.F.L.-C.I.O Goes to Ukraine." The Nation, 2 November.

Sims, Beth. 1992. Workers of the World Undermined: American Labor's Role in U.S.Foreign Policy. Boston: South End Press.

Sims, Beth. [1992] 2004. "Populism, Conservatism, and Civil Society in Haiti." Interhemispheric Resource Center. Right Web, March. http://rightweb.irconline.org/pdf/0403ned-haiti.pdf (September 25, 2012).

Slaney, Dave. 1988. "Solidarity and Self Interest." NACLA Report on the Americas 22(3): 28-36.

Smyth, Frank. 1987a. "Duarte's Secret Friends." The Nation, 14 March.

- 1987b. "AFL-CIO is Spanish for Union Busting." Washington Monthly 19(September).

Snider, Erin A., and David M. Faris. 2012. "The Arab Spring: U.S. Democracy Promotion in Egypt." Middle East Policy Council. http://www.mepc.org/journal/middle-east-policy-archives/arab-spring-usdemocracy-promotion-egypt (September 27, 2012).

Solidarity Center. 2003. "Unequal Equation: The Labor Code and Worker Rights in Haiti."American Center for International Labor Solidarity. http://www.solidaritycenter.org/files/UnequalEquation.pdf (September 27, 2012).

- 2004. "2003-2004 Annual Report.” American Center for International Labor Solidarity. http://www.solidaritycenter.org/files/AnnlRep2003 2004.pdf (September 27, 2012).

- 2005. “2004-2005 Annual Report.” American Center for International Labor Solidarity. http://solidaritycenter.org/files/annlrep2004_2005.pdf (September 27, 2012). 
- 2006. “2005-2006 Annual Report.” American Center for International Labor Solidarity.http://solidaritycenter.org/files/pubs_AnnualReport_2005_2006.pdf (September 27, 2012).

- 2007. "2006-2007 Annual Report." American Center for International Labor Solidarity. http://solidaritycenter.org/files/pubs_2006_2007_annualreport.pdf (September 27, 2012).

- 2008. “2008 Annual Report.” American Center for International Labor Solidarity. http://solidaritycenter.org/files/solidarity annualreport.pdf (September 27, 2012).

- 2009. "2009 Annual Report.” American Center for International Labor Solidarity. http://solidaritycenter.org/files/pubs_annual_report_2009.pdf (September 27, 2012).

- 2010. "2010 Annual Report.” American Center for International Labor Solidarity. http://solidaritycenter.org/Files/pubs_annual_report_2010.pdf (September 27, 2012).

Spalding Jr., Hobart. 1976. "U.S. and Latin American Labor: The Dynamics of Imperialist Control.” Latin American Perspectives 3(1): 45-69.

- 1988. “AIFLD Amok.” NACLA Report on the Americas 22(3): 20-23.

Spalding Jr., Hobart. 1992. "The Two Latin American Foreign Policies of the U.S. Labor Movement: The AFL-CIO Top Brass vs. Rank and File." Science \& Society 56(4): 421-439.

Sprague, Jeb. 2005. "Supporting a Leftist Opposition to Lavalas: The AFL-CIO's Solidarity Center and the Batay Ouvriye." Third World Traveler, 18 November. http://www.thirdworldtraveler.com/Labor/AFL_CIO_Opposes_Lavalas.html (September 25, 2012).

- 2006a. "Batay Ouvriye's Smoking Gun." ZNET. 10 January. http://www.zcommunications.org/batay-ouvriyes-smoking-gun-by-jeb-sprague (September 25, 2012).

- 2006b. "Failed Solidarity: The ICFTU, AFL-CIO, ILO, and ORIT in Haiti." Labor Notes, 28 September. http://labornotes.org/node/230 (September 25, 2012).

- 2006c. "Invisible Violence." Fairness and Accuracy in Reporting (FAIR), July/August. http://www.fair.org/index.php?page=2937 (September 27, 2012).

- 2007. “The Overthrow of Popular Democracy in Haiti: 2001-2004.” Master’s thesis. California State University. 
Statement of Assemblies of Caribbean People. 2004. "Statement of the Haitian Organizations that are Members of the Assembly of Caribbean People concerning the Presence of Jean Bertrand Aristide in Jamaica." Open Space World. http://www.openspaceworld.org/cgi/haitil.cgi?StatementofAssembliesofCarribeanPe ople (September 25, 2012).

Stokes, Doug, and Sam Raphael. 2010. Global Energy Security and American Hegemony. Baltimore: The Johns Hopkins University Press.

Stout, David. 2004. "Administration Dismissed Rumors That U.S. Kidnapped Aristide." The New York Times, 1 March.

Stroup, Sarah S. 2012. Borders Among Activists: International NGOs in the United States, Britain, and France. Ithaca: Cornell University Press.

Sunga, Lyal. 2007. "Dilemmas Facing NGOs in Coalition-Occupied Iraq". In Ethics in Action: The Ethical Challenges of International Human Rights Nongovernmental Organizations, ed. Daniel Bell and Jean-Marc Coicaud. Cambridge: MIT Press.

Sweeney, John. 2003a. "Statement by AFL-CIO President John Sweeney On the War with Iraq. " $A F L-C I O, 20$ March. http://www.aflcio.org/Press-Room/Press-

Releases/Statement-by-AFL-CIO-President-John-Sweeney-On-the87 (September 25, 2012).

- 2003b. "Sweeney Cover Letter to AFL-CIO Statement on War." KC Labor, 20 March. http://www.kclabor.org/sweeney_cover_letter to afl.htm (September 25, 2012).

Sweeney, John, and John Monks. 2003. "John Sweeney and John Monks Write to Bush and Blair." Roosevelt Adjunct Faculty Organization. January 30. http://www.rafo.org/anti-war/Sweeney-Monk-Letter.htm

Thomson, Alex. 1995. 'Incomplete Engagement: Reagan's South Africa Policy Revisited." The Journal of Modern African Studies 33(1): 83-101.

Toth, Charles W. 1967. "Samuel Gompers, Communism, and the Pan American Federation of Labor." The Americas 23(3): 273-278.

Upchurch, Martin. 2006. "Strategic dilemmas for trade unions in transformation: the experience of Serbia." South-East Europe Review for Labour and Social Affairs 4: 43-64.

U.S. Agency for International Development. 1993. Final Report: Midterm Evaluation: AIFLD-AID Cooperation Agreement in El Salvador. Washington, DC: Checchi and Company Consulting, Inc. 
U.S. Department of State. 2002. A Review of U.S. Policy Toward Venezuela, November 2001-April 2002. Washington, DC: Office of the Inspector General. http://oig.state.gov/documents/organization/13682.pdf (September 27, 2012).

U.S. General Accounting Office. 1996. National Security and International Affairs Division. GAO Report. U.S. Government Accountability Office. http://archive.gao.gov/papr2pdf/156758.pdf (September 25, 2012).

Waters, Robert A. Jr., and Gordon O. Daniels. 2006. ““When You're Handed money on a Platter, it's very hard to say "where are you getting this?'”: The AFL-CIO, the CIA, and British Guiana." Revue belge de philology et d'histoire 84(84-40): 1075-99.

Welch, Cliff. 1995. "Labor Internationalism: U.S. Involvement in Brazilian Unions, 1945-1965." Latin American Research Review 30(2): 61-89.

Wilentz, Sean. 1984. "Against Exceptionalism: Class Consciousness and the Americas Labor Movement, 1790-1920." International Labor and Working Class History 26(September): 1-24.

Windmuller, John P. 1956. "Foreign Affairs and the AFL-CIO." Industrial and Labor Relations Review 9(3): 419-432.

- 1963. "A Partner in American Foreign Policy?” Annals of the American Academy of Political Science 350(November): 104-114.

- 1967. "The Foreign Policy Conflict in American Labor." Political Science Quarterly 82(2): 205-234.

Worker to Worker Solidarity Committee. 2006. “AFL-CIO's Solidarity Center and National Endowment for Democracy (NED)." Third World Traveler. http://www.thirdworldtraveler.com/Labor/AFL_CIO_SolidarityCtr_NED.html (September 27, 2012).

Yates, Michael D. 2009. Why Unions Matter. New York: Monthly Review Press.

Zweig, Michael. 2005. "Iraq and the Labor Movement: The Remarkable Story of USLAW." New Labor Forum 14(3): 61-67.

**Note: for links that are not active www.waybackmachine.org is a very helpful tool. 
VITA

\section{G. NELSON BASS III}

1998-2002

B.S., Political Science

Appalachian State University

Boone, North Carolina

2002-2003

Travel in Latin America

2003-2006

Juris Doctor

University of Miami

Coral Gables, Florida

$2006-2012$

Doctoral Candidate

Department of Politics and International Relations

Florida International University

Miami, Florida

$2006-2009$

$2009-2011$

Teaching Assistant

Department of Politics and international Relations

Florida International University

Miami, Florida

Instructor, International Relations, Judicial Process and

Politics, International Political Economy

Florida International University

Miami, Florida

$2011-2012$

Visiting Instructor

Division of Humanities

Nova Southeastern University

Fort Lauderdale, Florida

$2012-2013$

Instructor

Division of Humanities

Nova Southeastern University

Fort Lauderdale, Florida

\section{PUBLICATIONS AND PRESENTATIONS}

Cox, Richard W., and G. Nelson Bass. 2012. "U.S. Labor in a Global Economy.” In Corporate Power in American Foreign Policy, ed. Richard W. Cox. New York:

Routledge. 